\title{
Monitoring Soil Erosion of a Burn Site in the Central Basin and Range Ecoregion: Final Report on Measurements at the Gleason Fire Site, Nevada
}

\author{
prepared by \\ J. J. Miller ${ }^{1}$, V. Etyemezian ${ }^{2}$, R. M. Shillito ${ }^{1}$, M. E. Cablk ${ }^{3}$, \\ L. K. Fenstermaker ${ }^{3}$, and D. S. Shafer ${ }^{4}$ \\ ${ }^{1}$ Division of Hydrologic Sciences, ${ }^{2}$ Division of Atmospheric Sciences, \\ ${ }^{3}$ Division of Earth and Ecosystem Sciences \\ Desert Research Institute \\ Nevada System of Higher Education \\ ${ }^{4}$ Department of Energy, \\ Grand Junction, Colorado
}

submitted to

Nevada Field Office

National Nuclear Security Administration

U.S. Department of Energy

Las Vegas, Nevada

October 2013

Publication No. 45254 
Reference herein to any specific commercial product, process, or service by trade name, trademark, manufacturer, or otherwise, does not necessarily constitute or imply its endorsement, recommendation, or favoring by the United States Government or any agency thereof or its contractors or subcontractors.

Available for sale to the public from:

U.S. Department of Commerce

National Technical Information Service

5301 Shawnee Road

Alexandria, VA 22312

Phone: 800.553.6847

Fax: 703.605.6900

Email: orders@ntis.gov

Online ordering: http://www.osti.gov/ordering.htm

Available electronically at http://www.osti.gov/bridge

Available for a processing fee to the U.S. Department of Energy and its contractors, in paper, from:

U.S. Department of Energy

Office of Scientific and Technical Information

P.O. Box 62

Oak Ridge, TN 37831-0062

Phone: 865.576.8401

Fax: 865.576.5728

Email: reports@adonis.osti.gov 


\title{
Monitoring Soil Erosion of a Burn Site in the Central Basin and Range Ecoregion: Final Report on Measurements at the Gleason Fire Site, Nevada
}

\author{
prepared by \\ J. J. Miller ${ }^{1}$, V. Etyemezian ${ }^{2}$, R. M. Shillito ${ }^{1}$, M. E. Cablk ${ }^{3}$, \\ L. K. Fenstermaker ${ }^{3}$, and D. S. Shafer ${ }^{4}$ \\ ${ }^{1}$ Division of Hydrologic Sciences, ${ }^{2}$ Division of Atmospheric Sciences, \\ ${ }^{3}$ Division of Earth and Ecosystem Sciences \\ Desert Research Institute \\ Nevada System of Higher Education \\ ${ }^{4}$ Department of Energy, \\ Grand Junction, CO
}

Publication No. 45254

submitted to

Nevada Field Office

National Nuclear Security Administration

U.S. Department of Energy

Las Vegas, Nevada

October 2013

The work upon which this report is based was supported by the U.S. Department of Energy under Contract \#DE-NA0000939. Approved for public release; further dissemination unlimited. 
THIS PAGE LEFT INTENTIONALLY BLANK 


\section{ABSTRACT}

The increase in wildfires in arid and semi-arid parts of Nevada and elsewhere in the southwestern United States has implications for post-closure management and long-term stewardship for Soil Corrective Action Units (CAUs) on the Nevada National Security Site (NNSS) for which the Nevada Field Office of the United States Department of Energy, National Nuclear Security Administration has responsibility. For many CAUs and Corrective Action Sites, where closure-in-place alternatives are now being implemented or considered, there is a chance that these sites could burn over at some time while they still pose a risk to the environment or human health, given the long half-lives of some of the radionuclide contaminants. This study was initiated to examine the effects and duration of wildfire on wind and water erodibility on sites analogous to those that exist on the NNSS. The data analyzed herein were gathered at the prescribed Gleason Fire site near Ely, Nevada, a site comparable to the northern portion of the NNSS.

Quantification of wind erosion was conducted with a Portable In-Situ Wind ERosion Lab (PI-SWERL) on unburned soils, and on interspace and plant understory soils within the burned area. The PI-SWERL was used to estimate emissions of suspendible particles (particulate matter with aerodynamic diameters less than or equal to 10 micrometers) at different wind speeds. Filter samples, collected from the exhaust of the PI-SWERL during measurements, were analyzed for chemical composition. Based on nearly three years of data, the Gleason Fire site does not appear to have returned to pre-burn wind erosion levels. Chemical composition data of suspendible particles are variable and show a trend toward pre-burn levels, but provide little insight into how the composition has been changing over time since the fire.

Soil, runoff, and sediment data were collected from the Gleason Fire site to monitor the water erosion potential over the nearly three-year period. Soil hydrophobicity (water repellency) was noted on burned understory soils up to 12 months after the fire, as was the presence of ash on the soil surface. Soil deteriorated from a strong, definable pre-fire structure to a weakly cohesive mass (unstructured soil) immediately after the fire. Surface soil structure was evident 34 months after the fire at both burned and unburned sites, but was rare and weaker at burned sites. The amount of runoff and sediment was highly variable, but runoff occurred more frequently at burned interspace sites compared to burned understory and unburned interspace sites up to 34 months after the burn. No discernible pattern was evident on the amount of sediment transported, but the size of sediment from burned understory sites was almost double that of burned and unburned interspace soils after the fire, and decreased over the monitoring period. Curve numbers, a measure of the runoff potential, did not indicate any obvious runoff response to the fire. However, slight seasonal changes in curve numbers and runoff potential and, therefore, post-fire runoff response may be a function of fire impacts as well as the time of year that precipitation occurs. Site (interspace or understory) differences in soil properties and runoff persisted even after the fire.

Vegetation data showed the presence of invasive grasses after the fire. Results from analysis of wind and water coupled with the spatial analysis of vegetation suggest that wind erosion may continue to occur due to the additional exposed soil surface (burned understory sites) until vegetation becomes re-established, and runoff may occur more 
frequently in interspace sites. The potential for fire-related wind erosion and water erosion may persist beyond three years in this system. 


\section{ACKNOWLEDGEMENTS}

The assistance of the following personnel is gratefully acknowledged: T. Caldwell, S. Campbell, K. Chief, W. Forsee, J. Healey, W. Meyer, S. Mizell, G. Nicolich, and S.

Zitzer. The authors also greatly appreciate the thoughtful comments of the reviewers: $M$. Berli and P. Verburg.

The research here was performed under contract no. DE-NA0000939 for the U.S. Department of Energy, National Nuclear Security Administration, Nevada Field Office. The collection of data immediately before and after the fire was made possible through funding from the National Science Foundation Grants for Rapid Response Research (no. EAR-0952272), and the DRI Research Advisory Council. In addition, the U.S. Bureau of Land Management, Ely (Nevada) District Office, provided permits for the field measurements and data on pre-fire fuel loads and vegetation composition. 
THIS PAGE LEFT INTENTIONALLY BLANK 


\section{CONTENTS}

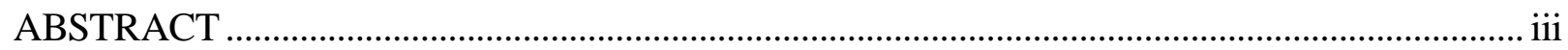

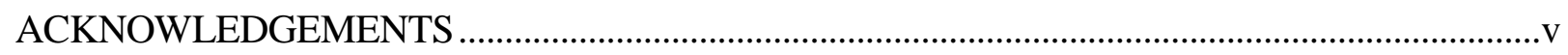

LIST OF FIGURES …………………………………................................................ vii

LIST OF TABLES ……………………………………………………………………... ix

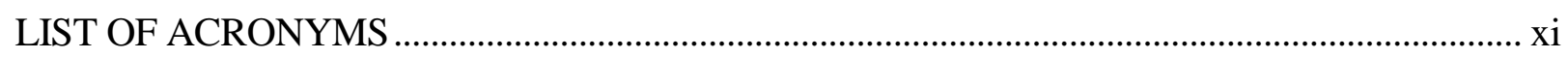

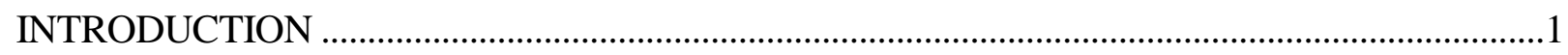

THE UPPER GLEASON SITE AND PRESCRIBED BURN ...........................................................

POST-FIRE DUST EMISSION AND THE POTENTIAL FOR SOIL EROSION BY

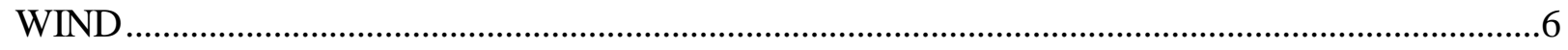

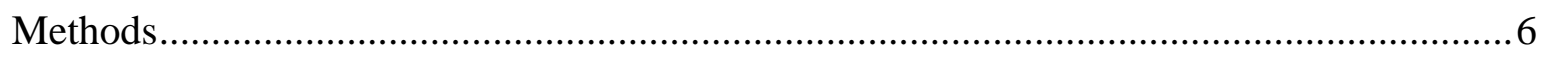

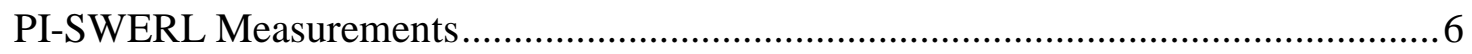

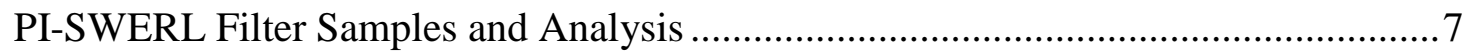

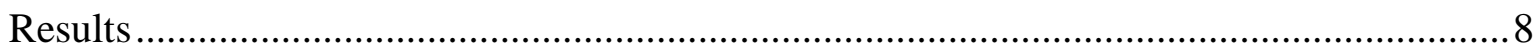

POST-FIRE SOIL AND RUNOFF PROPERTIES AND THE POTENTIAL FOR

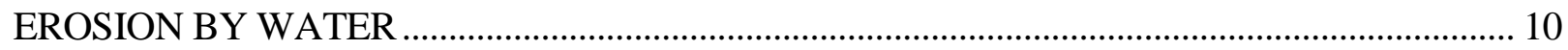

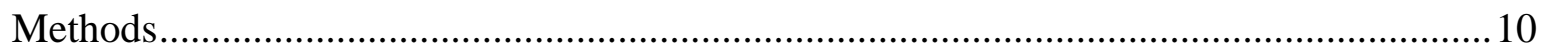

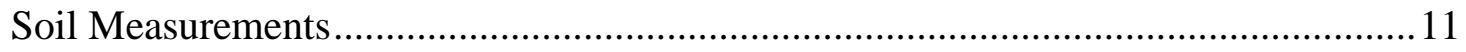

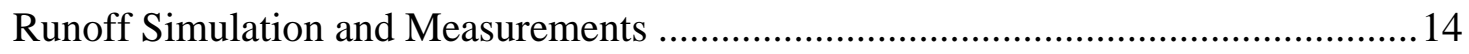

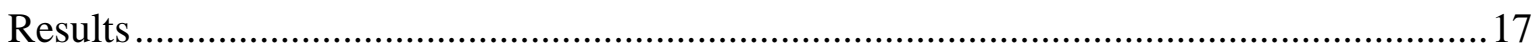

Soil Properties and Hydraulic Characterization........................................................... 17

Runoff Generation, Sedimentation, and Curve Numbers ...........................................20

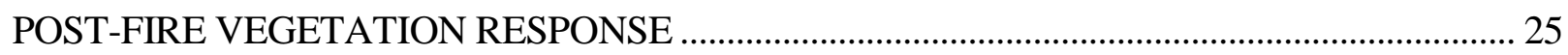

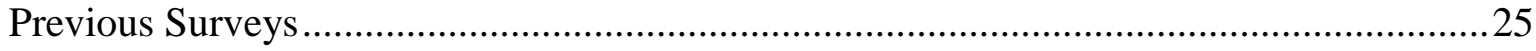

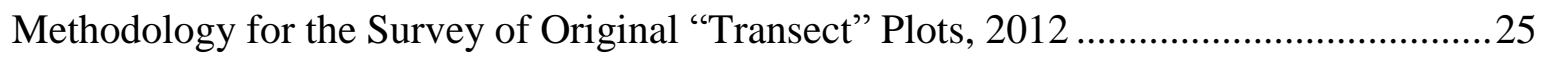

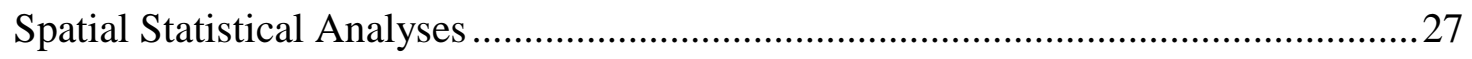

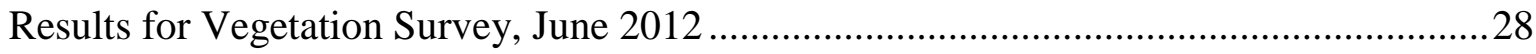

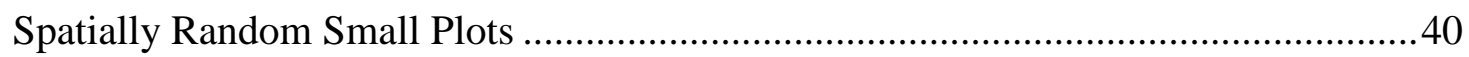

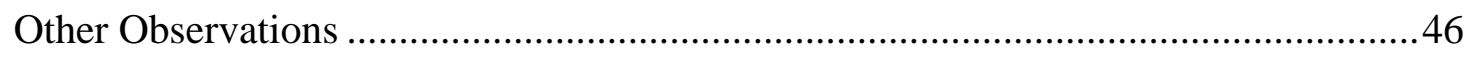

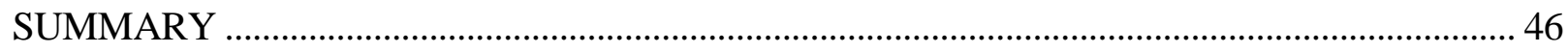

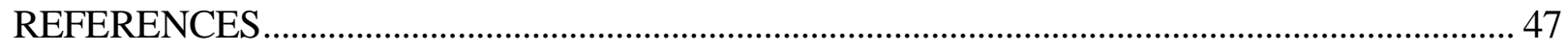

APPENDIX A: SAMPLING DATES .............................................................................

APPENDIX B: SOIL MEASUREMENT SITES ……………………………………......... B-1

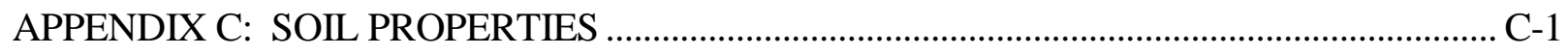

APPENDIX D: RAINFALL SIMULATOR HYDROGRAPHS, 2009-2012 ………………...... D-1

APPENDIX E: SOIL MOISTURE DURING RAINFALL SIMULATION, 2009-2012...............E-1

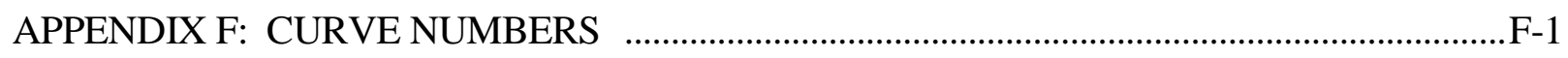

APPENDIX G: PLANT LIST AND CODES................................................................................ G-1 


\section{LIST OF FIGURES}

1. Major ecoregions on the Nevada National Security Site (NNSS) with fire-prone vegetative units highlighted. .........................................................................................

2. Gleason area map showing field site with 2009 fire area and a previous (2007)

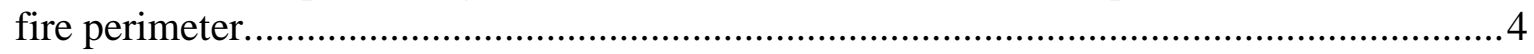

3. Pre- (top) and post-burn (bottom) views of the Gleason Fire site. .....................................5

4. Cumulative emissions $\left(\mathrm{g} \mathrm{m}^{-2}\right)$ calculated at different points during the PI-SWERL

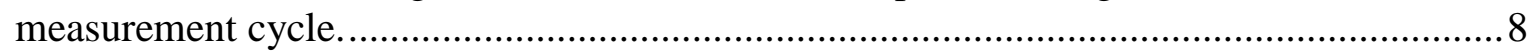

5. PI-SWERL results, normalized to unburned control area unburned soils............................9

6. Ratio of elemental carbon ([EC]) to mineral soil ([Soil]) from $\mathbf{P M}_{10}$ filter samples collected during different field measurements. .................................................................10

7. Set of eight modified MDTIs linked to a datalogger......................................................... 12

8. Photograph of portable rainfall simulator (background) before installation over

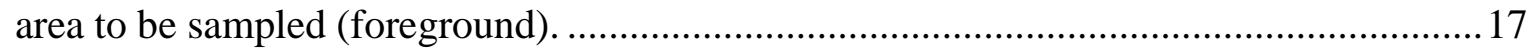

9. (a) Soil porosity, (b) saturated hydraulic conductivity, and (c) soil air

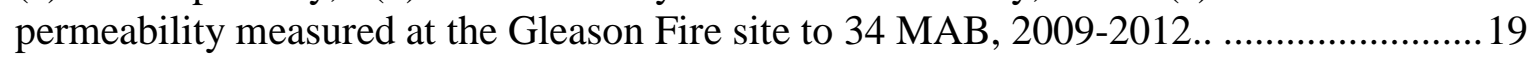

10. Surface soil structure at Gleason Fire site in unburned (left) and post-burn (right) conditions.

11. Measurements of soil surface strength expressed as cohesion at $34 \mathrm{MAB}$ using a shear vane tester and a pocket penetrometer..

12. Total runoff volumes and frequency of occurrence for rainfall simulator at the Gleason Fire site to $34 \mathrm{MAB}$..

13. Median sediment size, $d_{50}(\mu \mathrm{m})$, for sediment sampled during rainfall simulation to $34 \mathrm{MAB}$.......

14. Curve numbers (CNs) calculated from all rainfall simulations (using All

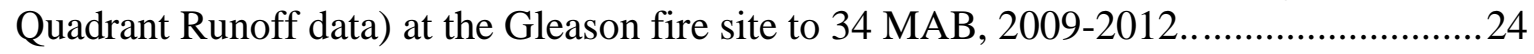

15. Photograph of Plot 1, surveyed on June 27, 2012 .....................................................2 29

16. Survey results (abundance and diversity) from Plot 1 show it is dominated by three species and perennial grasses (PEGR).....................................................................31

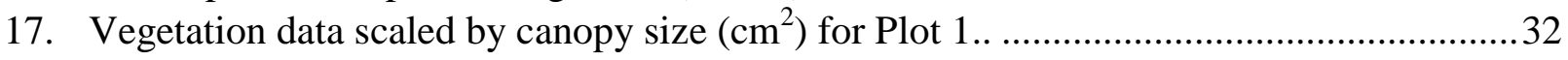

18. Results from ANN spatial pattern analysis for Plot 1.........................................................3

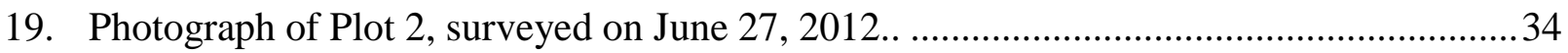

20. Survey results (abundance and diversity) from Plot 2 show the plot dominated by one species, Eriastrum sparsiflorum (ERSP) known as the Great Basin

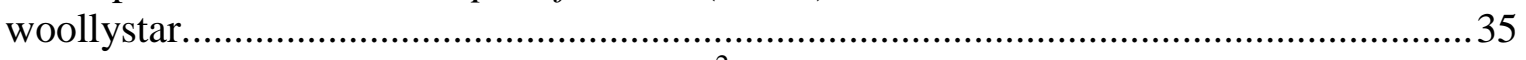

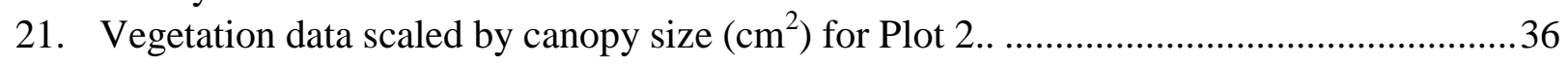

22. Results of ANN for Plot 2 shows the spatial pattern of vegetation is highly clustered..

23. Survey results (abundance and diversity) from Plot 3 show the plot dominated by one species, Eriastrum sparsiflorum (ERSP) known as the Great Basin woollystar.

24. Vegetation data scaled by canopy size $\left(\mathrm{cm}^{2}\right)$ for Plot 3 . 
25. Results of ANN for Plot 3 shows the spatial pattern of vegetation is clustered...............40

26. Results from 2011 and 2012 vegetation surveys overlaid in space for comparison...........41

27. Location of random small plots surveyed on June 27, 2012 .....................................42

28. Survey results (abundance and diversity) across all random small plots. .......................43

29. Diversity of species recorded in each of 16 random small plots. ..................................44

30. Species richness for each of the paired random small plots surveyed.............................45

\section{LIST OF TABLES}

1. Averages and coefficients of variation* (in parenthesis) for selected soil parameters from the Gleason burn site (2009-2012)................................................ 18

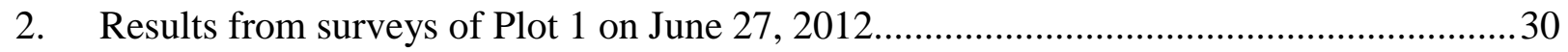

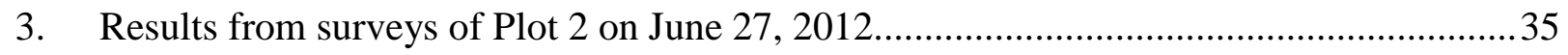

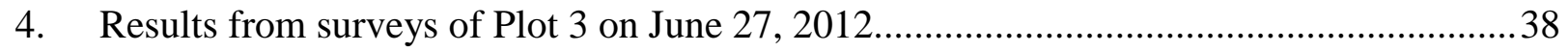

5. Abundance and diversity combined across all plots.................................................43

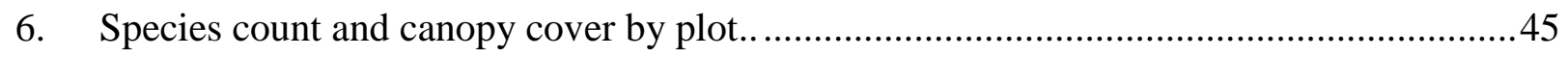




\section{LIST OF ACRONYMS}

ac

ANN

BLM

${ }^{\circ} \mathrm{C}$

CAS

CAU

CCRFCD

$\mathrm{cm}$

$\mathrm{CN}$

$\mathrm{COC}$

DOE

$\mathrm{d}_{50}$

[EC]

EPA

${ }^{\circ} \mathrm{F}$

$\mathrm{ft}$

g

GPS

ha

$\mathrm{hr}$

I

$\mathrm{I}_{\mathrm{a}}$

IMPROVE

in

$\mathrm{k}_{\mathrm{a}}$

$\mathrm{kPa}$

$\mathrm{kph}$

$\mathrm{K}_{\mathrm{s}}$

1

$\mathrm{lb}$

$\mathrm{m}$

MAB

MDTI

$\mu \mathrm{m}$

$\min$ acres

Average Nearest Neighbor

Bureau of Land Management

degree Celsius

Corrective Action Site

Corrective Action Unit

Clark County Regional Flood Control District

centimeters

Curve Number

Contaminant of Concern

Department of Energy

diameter of particles for which 50 percent by weight of material is finer

elemental carbon concentration

Environmental Protection Agency

degrees Fahrenheit

feet

gram

global positioning system

hectare

hour

Moran's I statistic

Initial abstraction

Interagency Monitoring of PROtected Visual Environments

inches

air permeability

kilopascals

kilometers per hour

saturated hydraulic conductivity

liter

pound

meter

months after burn

mini disk tension infiltrometer

micrometers

minute 


$\begin{array}{ll}\text { mg } & \text { milligrams } \\ \text { ml } & \text { milliliters } \\ \text { mm } & \text { millimeters } \\ \text { mph } & \text { miles per hour } \\ \text { NFO } & \text { Nevada Field Office } \\ \text { NNSA } & \text { National Nuclear Security Administration } \\ \text { NNSS } & \text { Nevada National Security Site } \\ \text { NOAA } & \text { National Oceanic and Atmospheric Administration } \\ \text { NRCS } & \text { Natural Resource Conservation Service } \\ \text { NTTR } & \text { Nevada Test and Training Range } \\ \text { OM } & \text { organic matter } \\ \text { p } & \text { probability } \\ \text { PI-SWERL } & \text { Portable In-Situ Wind ERosion Lab } \\ \text { PM } & \text { particulate matter } \\ \text { PM } 10 & \text { particulate matter with diameters less than 10 micrometers } \\ \text { psi } & \text { pounds per square inch } \\ \text { R } & \text { coefficient of determination } \\ \text { RPM } & \text { revolutions per minute } \\ \text { SCS } & \text { Soil Conservation Service } \\ \text { sec } & \text { second } \\ \text { [Soil] } & \text { mineral soil concentration } \\ \text { SSI } & \text { size selective inlet } \\ \text { TTR } & \text { Tonopah Test Range } \\ \text { U.S. } & \text { United States } \\ \text { WDPT } & \text { water drop penetration time } \\ \text { z } & \text { z-score measure } \\ & \end{array}$


THIS PAGE LEFT INTENTIONALLY BLANK 


\section{INTRODUCTION}

The increase in wildfires in arid and semi-arid parts of Nevada and elsewhere in the southwestern United States (U.S.) has implications for post-closure management and long-term stewardship for Soil Corrective Action Units (CAUs) on the Nevada National Security Site (NNSS) for which the Nevada Field Office (NFO) of the U.S. Department of Energy, National Nuclear Security Administration (DOE/NNSA) has responsibility. For many CAUs and Corrective Action Sites (CASs), where closure-in-place alternatives are now being implemented or considered, there is a chance that these sites could burn over at some time while they still pose a risk to the environment or human health, given the long half-lives of some of the radionuclide contaminants of concern (COCs) (Shafer et al., 2007; Shafer and Gomes, 2009).

Although it would be ideal to conduct a fire-related study at a radionuclide contaminated site on the NNSS, it is more practical to examine fires in environments analogous to where Soil CAUs exist. Two studies were initiated to specifically examine the effects and duration of fire on wind and water erodibility and vegetative recovery of the burned sites on regions within the NNSS defined by Hansen and Ostler (2004) (Figure 1). The first of these studies was undertaken at the Jacob Fire site, representative of the ecotone (transition zone between two ecological systems) between the Mojave Desert and the Great Basin Desert. Ostler and Hansen (2001) refer to these ecotones as "Transition Desert," which is a climatic definition based on early work by Beatley (1976).

The second (present) study was undertaken at a prescribed burn site near Ely, Nevada. This second site, termed the Gleason Fire site, represents the Central Basin and Range ecoregion and the Great Basin Desert, which is characteristic of the northern portion of the NNSS and most of the Tonopah Test Range (TTR). The second largest number of Soil CASs are found within the Central Basin and Range ecoregion/Great Basin Desert, including those in the higher elevations of the NNSS and at the TTR where lightning strikes are most common.

The Gleason Fire site is located in an area managed by the Bureau of Land Management (BLM) at a location that afforded the unique opportunity to obtain data specific to a prescribed burn. The Desert Research Institute was able to leverage its funding from the NNSA/NFO to obtain a National Science Foundation RAPID Grant Award to collect data on soil structure and soil hydraulic properties a few days before and after the burn. The fire occurred on August 13, 2009. Wind erosion measurements began in August, 2009, immediately after the fire. Additional wind erosion measurements were made in in May, 2010, nine months after the burn (9 MAB); June, 2010 (10 MAB); August, 2010 (12 MAB); May, 2011 (21 MAB); August, 2011 (24 MAB); and June, 2012 (34 MAB). Runoff and sediment sampling began in June, 2010 (10 MAB), and continued in August, 2010 (12 MAB); June, 2011 (22 MAB); September, 2011 (25 MAB); and June, 2012 (34 MAB). Vegetation data from transect sampling were recorded in September, 2010 (13 MAB); June, 2011 (22 MAB); and June, 2012 (34 MAB). The sampling schedule was influenced by the elevation of the Gleason Fire site (approximately 2,200 meters [m], or 7,218 feet $[\mathrm{ft}]$ ), which limited sampling to the months of May to November when the soil was snow free and dry enough for sampling (Appendix A). 


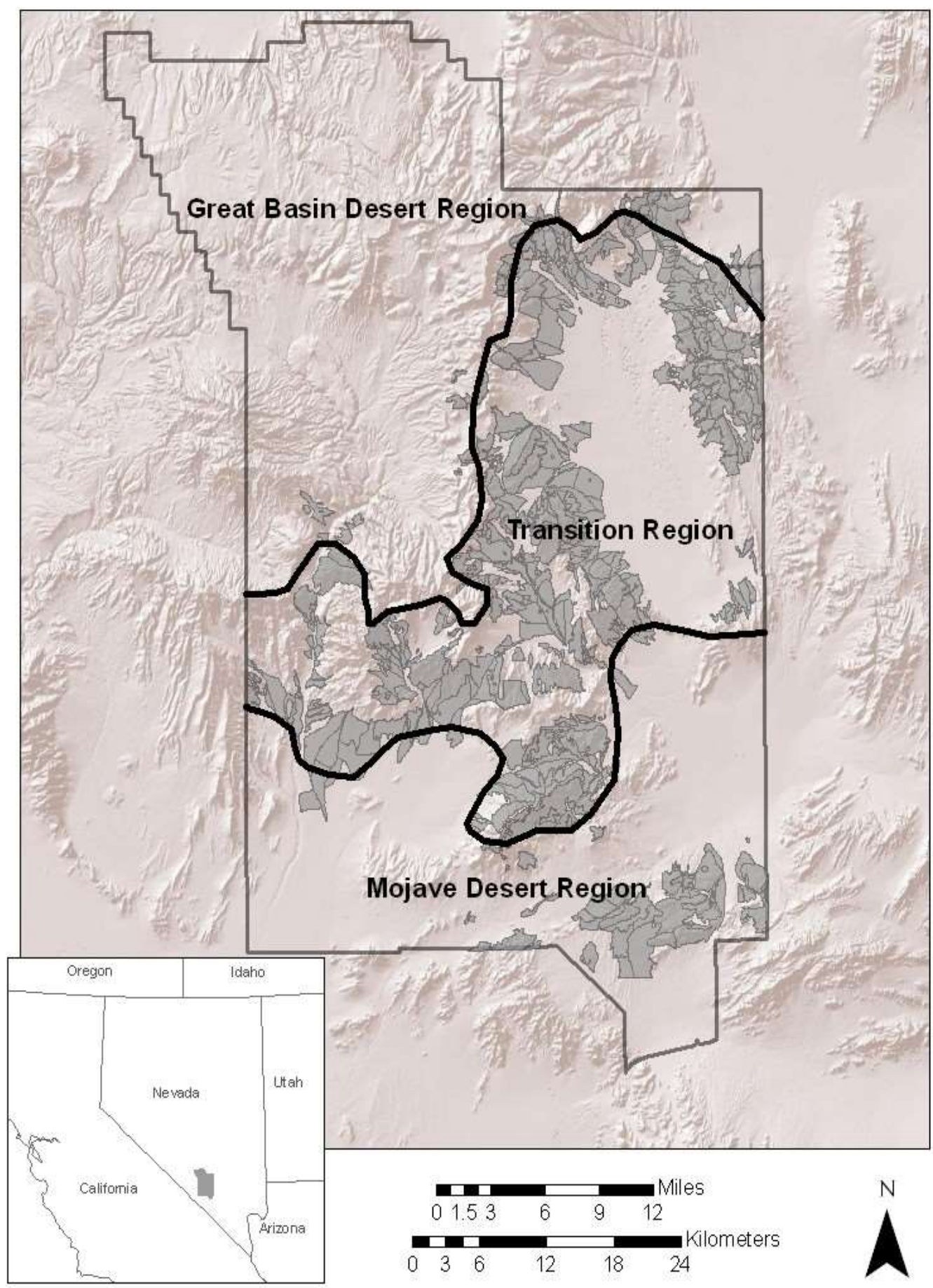

Figure 1. Major ecoregions on the Nevada National Security Site (NNSS) with fire-prone vegetative units highlighted. Data from Hansen and Ostler (2004). 
The basic approach to characterize the effects of fire on the potential for wind and water erosion was to conduct measurements on soils in areas that were burned and to make parallel measurements in areas that were part of the same landscape but were not burned. Soil measurements in the unburned control sites provided a benchmark for comparing how fire may have affected the site. Past research (Shafer et al., 2010) has shown that vegetation differentially influences wind and water erosion by trapping wind-borne material and concentrating biotic activity (e.g., roots, burrowing fauna). Therefore, site vegetation was surveyed. The spatial location, species type, and basic physical measurements were recorded and analyzed. Ultimately, the project objectives were to: (a) determine source areas and types of particles available in post-fire systems for wind and water erosion; (b) monitor their persistence over time; and (c) measure fire-related changes in vegetative cover and composition.

\section{THE UPPER GLEASON SITE AND PRESCRIBED BURN}

This study was undertaken at the Gleason Fire site, which is classified as Central Basin and Range ecoregion (level III) (U.S. Environmental Protection Agency [EPA], 2006). Northern areas on the NNSS fall within this ecoregion and important Soil CAUs here include the locations of the Schooner, Palanquin, Cabriolet, Johnny Boy, Little Feller I and II, Danny Boy device tests, and the Buggy sites. In addition, the results of the Gleason Fire have some bearing on the Project Roller Coaster Plutonium dispersal tests, particularly Double Tracks on the Nevada Test and Training Range (NTTR), as well as the Clean Slate tests on the TTR, although the soils at these sites are more alkaline than those of the mesas on the NNSS.

The Gleason Fire site (Figure 2$)$ is located in east-central Nevada $\left(39^{\circ} 23\right.$ ' $43^{\prime \prime}$ North, $115^{\circ} 03 ' 57^{\prime}$ 'West), at an elevation of 2,183-2,397 $\mathrm{m}(7,100-7,800 \mathrm{ft})$ within the boundaries of the Great Basin Desert. An area of 155 hectares (383 acres), covered with mixed sagebrush and pinion-juniper plant communities, was burned. The BLM estimated that pre-fire fuel loads would result in a low to medium intensity fire. The prescribed fire was conducted on August 13, 2009 and was the last in a series of prescribed fires conducted between 2007 and 2009 in the Upper Gleason Creek Watershed. The fire was ignited with a heavy drip torch along the southern boundary of the planned burn area and lasted for approximately six hours. Soil temperature probes installed at the fire site prior to the burn recorded peak soil temperatures of 326 degrees Celsius $\left(\left[{ }^{\circ} \mathrm{C}\right], 618.8\right.$ degrees Fahrenheit $\left.\left[{ }^{\circ} \mathrm{F}\right)\right]$ ) at a depth of 1.0 centimeter $\left([\mathrm{cm}], 0.39\right.$ inches [in]) in the soil, and $81^{\circ} \mathrm{C}$ $\left(178^{\circ} \mathrm{F}\right)$ and $44^{\circ} \mathrm{C}\left(112^{\circ} \mathrm{F}\right)$ at depths of $3.5 \mathrm{~cm}(1.4 \mathrm{in})$ and $6.5 \mathrm{~cm}(2.6 \mathrm{in})$, respectively, during the fire. Soil temperatures returned to pre-burn levels after about 20 hours (Chief et al., 2012). Nearly all surface plant material was burned with occasional singed remains of larger shrubs and trees. Ash and charred soils clearly delineated interspace and understory areas after the fire (Figure 3).

Site characteristics at the Gleason Fire site include:

- Sagebrush (Artemisia spp.) steppe and pinyon pine (Pinus spp.) and juniper (Juniperus osteosperma) community, 25 kilometers (15.5 miles) west of Ely, Nevada (Chief et al., 2012; Shafer et al., 2010).

- The average annual air temperature in Ely, $\mathrm{NV}$ is $7.1^{\circ} \mathrm{C}\left(45^{\circ} \mathrm{F}\right)$ (National Climatic Data Center, 2000).

- Precipitation over the burn site varies between about 200 to 400 millimeters (mm) (7.87 to 15.7 in) annually depending on elevation in the watershed. It occurs mainly as 
winter snow with spring and fall thundershowers and rains (Thompson and MacFarlan, 2007).

- The soils are gravelly loams and gravelly clay loams, found on alluvial fan piedmonts. Soils are shallow to moderately deep and well drained, with gravels, cobbles, and stones (Chief et al., 2012).

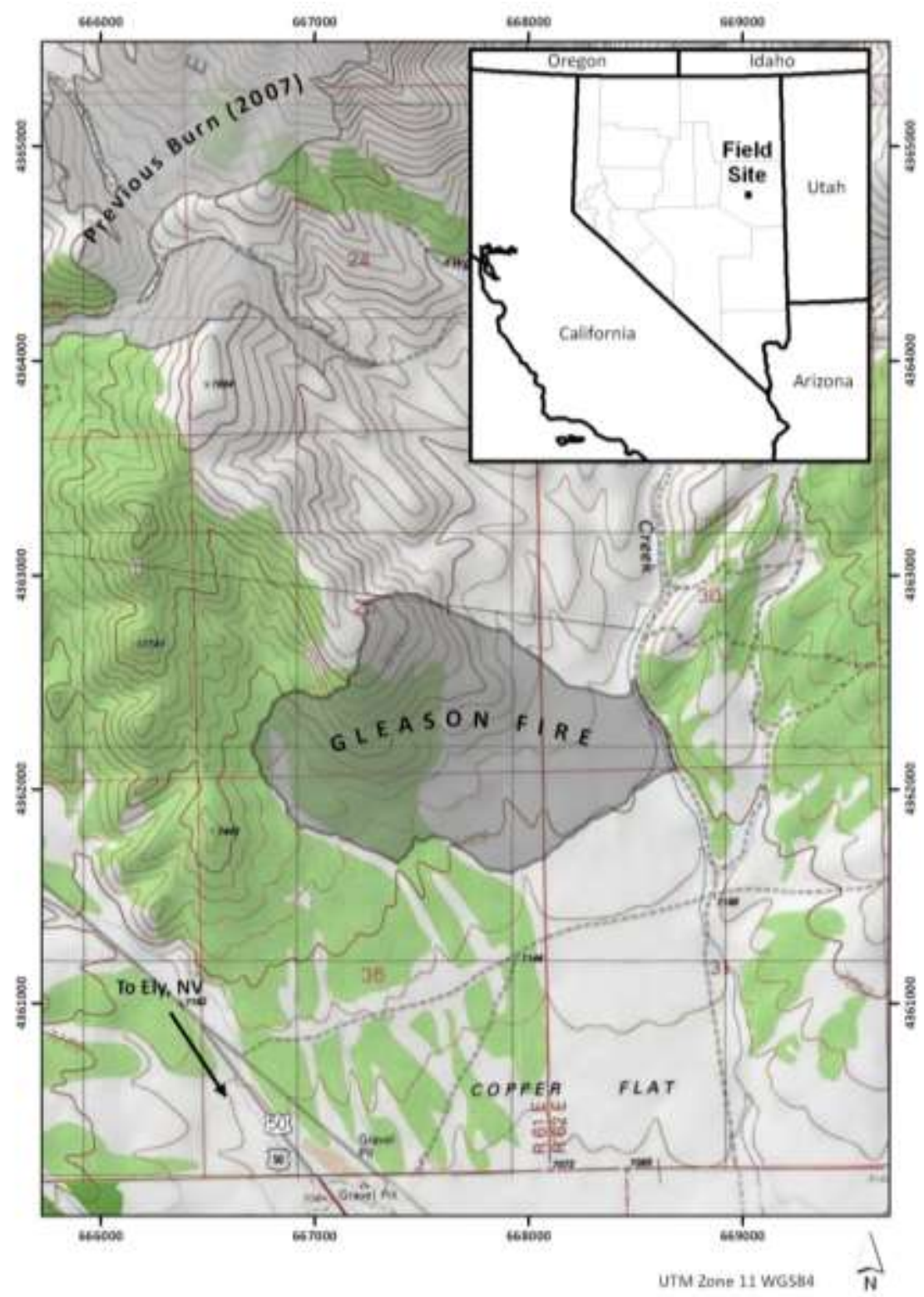

Figure 2. Gleason area map showing field site with 2009 fire area and a previous (2007) fire perimeter. 

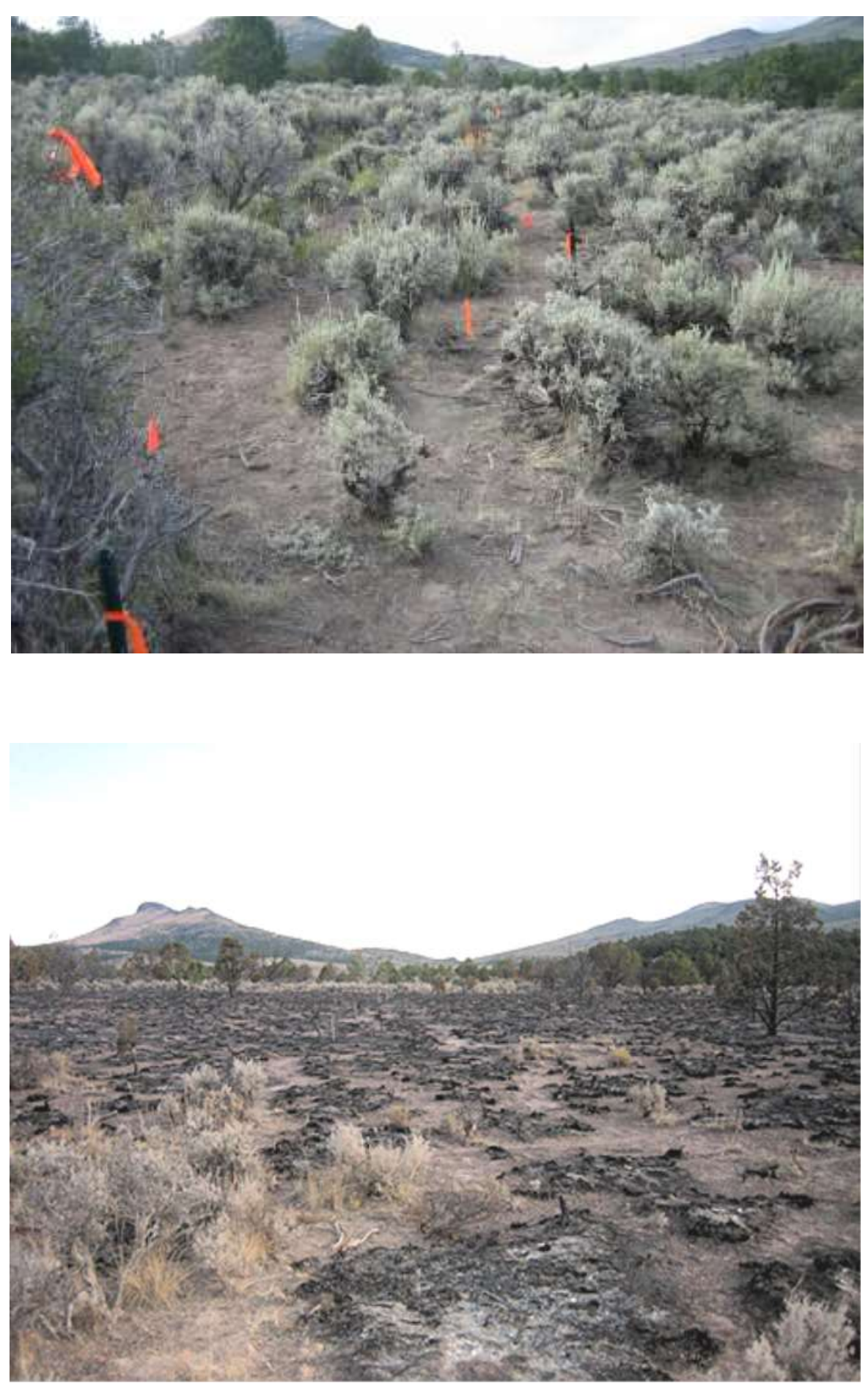

Figure 3. Pre- (top) and post-burn (bottom) views of the Gleason Fire site. Stakes visible in the center of both images show the location of pre- and immediate post-burn soil sampling sites. 


\section{POST-FIRE DUST EMISSION AND THE POTENTIAL FOR SOIL EROSION BY WIND}

\section{Methods}

\section{PI-SWERL Measurements}

A Portable In-Situ Wind ERosion Lab (PI-SWERL) was used to assess the potential for dust emission and wind erosion from the fire-affected soil surface (Etyemezian et al., 2007; Sankey et al., 2011). The PI-SWERL is a small, highly portable wind tunnel device used to estimate the abundance and composition of airborne particulate matter (PM) with aerodynamic diameters less than 10 micrometers $\left([\mu \mathrm{m}], 3.9 \times 10^{-4}\right.$ in $)-\mathrm{PM}_{10}$-at various simulated wind speeds. $\mathrm{PM}_{10}$ is the health-based air quality standard established by the EPA, which focuses on small particles that can reach the lower regions of the human respiratory tract, affecting breathing and damaging lung tissue.

To make measurements, the PI-SWERL was placed on the soil surface and dust in the PI-SWERL was suspended within the 30-cm (12-in) diameter chamber by a flat, rotating annular ring. The concentration of suspended material was measured by a nephelometer-style dust monitor (TSI, Dust Trak Model 8520). For all measurements, a hybrid ramp/step measurement cycle was used. The cycle consisted of:

1. a 60 -second clean air flush,

2. sharp acceleration to 500 revolutions per minute (RPM),

3. a 60 -second linear ramp to 2,000 RPM,

4. maintain 2,000 RPM for 60 seconds,

5. 60-second ramp to 3,000 RPM,

6. maintain 3,000 RPM for 90 seconds, and

7. turn off motor and clean air flush for 60 seconds.

Each RPM value corresponds to a friction velocity, $u *$, that is a measure of the amount of wind shear applied to a soil surface. Friction velocity can be related to surface wind speed (measured at a height above ground level) and the surface roughness with the Prandtl equation (1963):

$$
\frac{u_{r e f}}{u_{*}}=\frac{1}{\kappa} \cdot \ln \left(\frac{z_{r e f}}{z_{0}}\right)
$$

where $u_{r e f}$ is the wind speed measured at a reference height, $z_{\text {ref }}$ (usually $10 \mathrm{~m}, 32.8 \mathrm{ft}$ ), $\kappa$ is the von Karman constant equal to 0.41 , and $z_{0}$ is the aerodynamic roughness height. The roughness height determines how the wind speed translates into shear stress at the soil surface. Values of $z_{0}$ vary depending on the physical roughness of a surface. Typical values are $0.2 \mathrm{~mm}\left(7.9 \times 10^{-3} \mathrm{in}\right)$ 
for smooth ice, $30 \mathrm{~mm}$ (1.18 in) for grasslands, $500 \mathrm{~mm}$ (19.69 in) for urban areas, and $5 \mathrm{~mm}$ (0.20 in) for flat desert terrain.

Cumulative emissions in grams per square meter $\left(\mathrm{g} \mathrm{m}^{-2}\right)$ were calculated at the end of the ramp to 2,000 RPM, at the end of the 2,000 RPM step, at the end of the ramp to 3,000 RPM, and at the end of the 3,000 RPM step (Figure 4). Values of cumulative emissions at each of these points were averaged over replicate measurements for the same types of location. For example, for all PI-SWERL measurements completed on burned drainage soils, the cumulative emissions at the end of the ramp to 2,000 RPM were averaged together. For reference, assuming that the roughness height for a desert surface is $5 \mathrm{~mm}(0.20 \mathrm{in}), 3,000 \mathrm{RPM}$ translates roughly to a sustained wind speed of approximately 47 kilometers per hour ([kph], 28 miles per hour [mph]) at the Gleason Fire site.

The characteristics of airborne particulate matter in smoke during the Gleason Fire were measured and documented. The results were published in a separate report (Etyemezian et al., 2011).

$\underline{\text { PI-SWERL Filter Samples and Analysis }}$

Filter samples were collected at the exhaust port of the PI-SWERL chamber. The filter sampling apparatus included size selective inlets (SSI) to collect only particles in the $\mathrm{PM}_{10}$ size range, a flow control valve to ensure that flow rates (five liters per minute $\left[1 \mathrm{~min}^{-1}\right], 0.18$ cubic feet per minute $\left[\mathrm{ft}^{3} \mathrm{~min}^{-1}\right]$ ) were appropriate for the correct operation of the SSI, a filter holder, and suction source to maintain flow through the filters. Particles were collected on two types of filters (Teflon ${ }^{\circledR}$ and quartz fiber) in each case. Teflon ${ }^{\circledR}$ filters were subjected to gravimetric analysis (for particle mass) and X-ray fluorescence spectroscopy to quantify the elemental composition of airborne matter. The amount of soil material ([Soil]) in the sample was inferred through the assumption that silicon ( $\mathrm{Si}$ ), aluminum $(\mathrm{Al})$, iron $(\mathrm{Fe})$, calcium $(\mathrm{Ca})$, and titanium (Ti) existed in their metal oxide form in the soil. Following the Interagency Monitoring of PROtected Visual Environments (IMPROVE) equation (Malm et al., 1994), the mass of $\mathrm{PM}_{10}$ associated with soil was:

$$
[\text { Soil }]=2.20 *[\mathrm{Al}]+2.49 *[\mathrm{Si}]+1.63 *[\mathrm{Ca}]+2.42 *[\mathrm{Fe}]+1.94 *[\mathrm{Ti}]
$$

where the concentrations of metals were determined from X-ray fluorescence spectroscopy of the Teflon ${ }^{\circledR}$ filters. A portion of the quartz-fiber filter was analyzed for elemental carbon, organic carbon and carbonate using a thermal/optical carbon analyzer that is based on the preferential oxidation of organic carbon and elemental carbon ([EC]) compounds at different temperatures. Elemental or black carbon is primarily a product of combustion processes, such as the burning of fossil fuels or biofuels. The chemical signature of the fire was determined through the ratio of $[\mathrm{EC}] /[$ Soil] . For a burned site, an [EC]/[Soil] ratio higher than for an unburned site would indicate more combustible material (e.g., ash) content in the airborne particulate matter. 


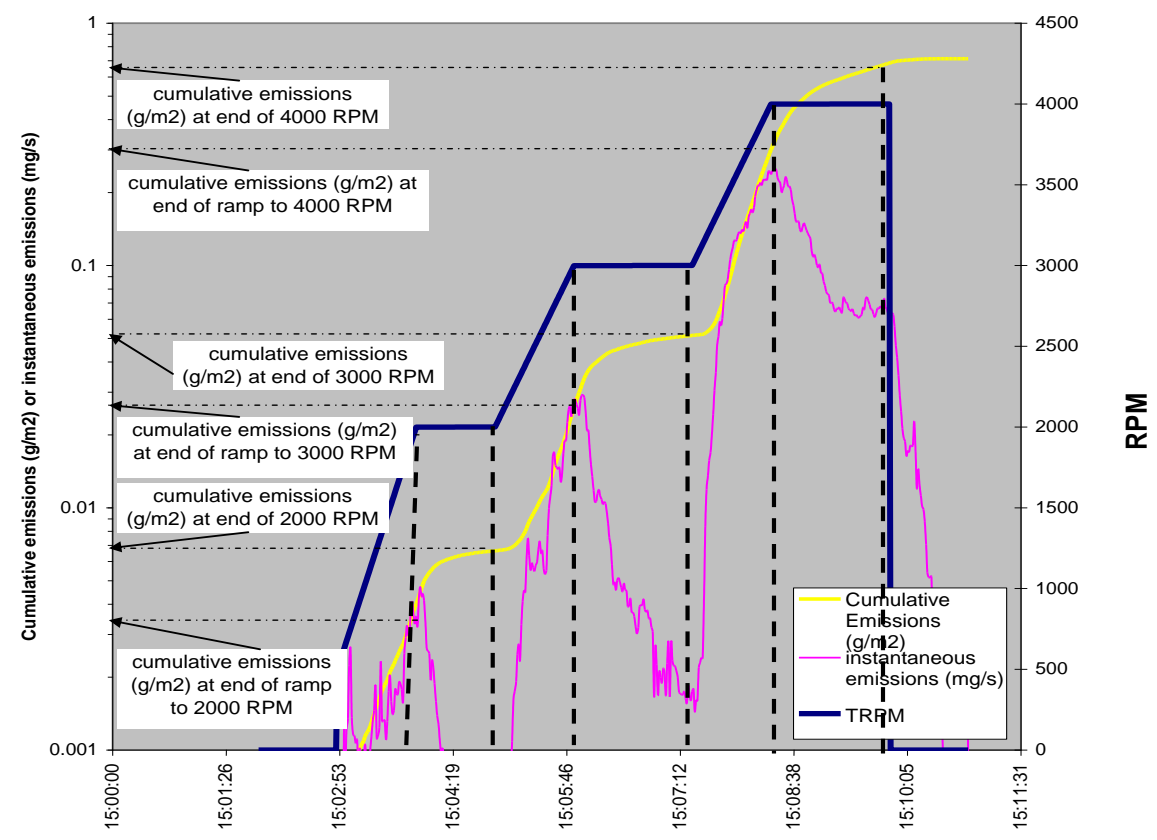

Figure 4. Cumulative emissions $\left(\mathrm{g} \mathrm{m}^{-2}\right)$ calculated at different points during the PI-SWERL measurement cycle.

The PI-SWERL was used to sample three soil conditions at the Gleason Fire site: burned understory soils, burned interspace soils, and unburned interspace soils. Four PI-SWERL replicates were recorded on each burned soil site, and eight on unburned soils. The unburned soil data pertains only to unburned interspace soils. Nevertheless, the comparison of data between unburned interspace sites and all burned sites (interspace and understory) is valid. Soil and material beneath vegetation is not a source of suspended particulate matter, especially at the Gleason site, where these areas are protected from wind currents by the vegetation-i.e., only unburned interspace sites are considered sources of suspended airborne particulate matter (Sankey et al., 2011). In burned areas, both interspace sites and formerly understory sites are sources of airborne particulate matter. PI-SWERL data from the Gleason Fire were collected on-site immediately after the burn in August, 2009 (Burn); nine months after the burn (9 MAB); June, 2010 (10 MAB); August, 2010 (12 MAB); May, 2011 (21 MAB); August, 2011 (24 MAB); and June, 2012 (34 MAB) (Appendix A).

\section{Results}

Figure 5 shows the $\mathrm{PM}_{10}$ emission abundance for the study period as measured by the PI-SWERL. For clarification, all burned soil data per time period were scaled relative to (divided by) unburned measurements for that time period - by definition, all unburned measurements were then equal to unity. Error bars illustrate the amount of variability in the data; overlapping error bars suggest that differences in means may not be statistically significant. 


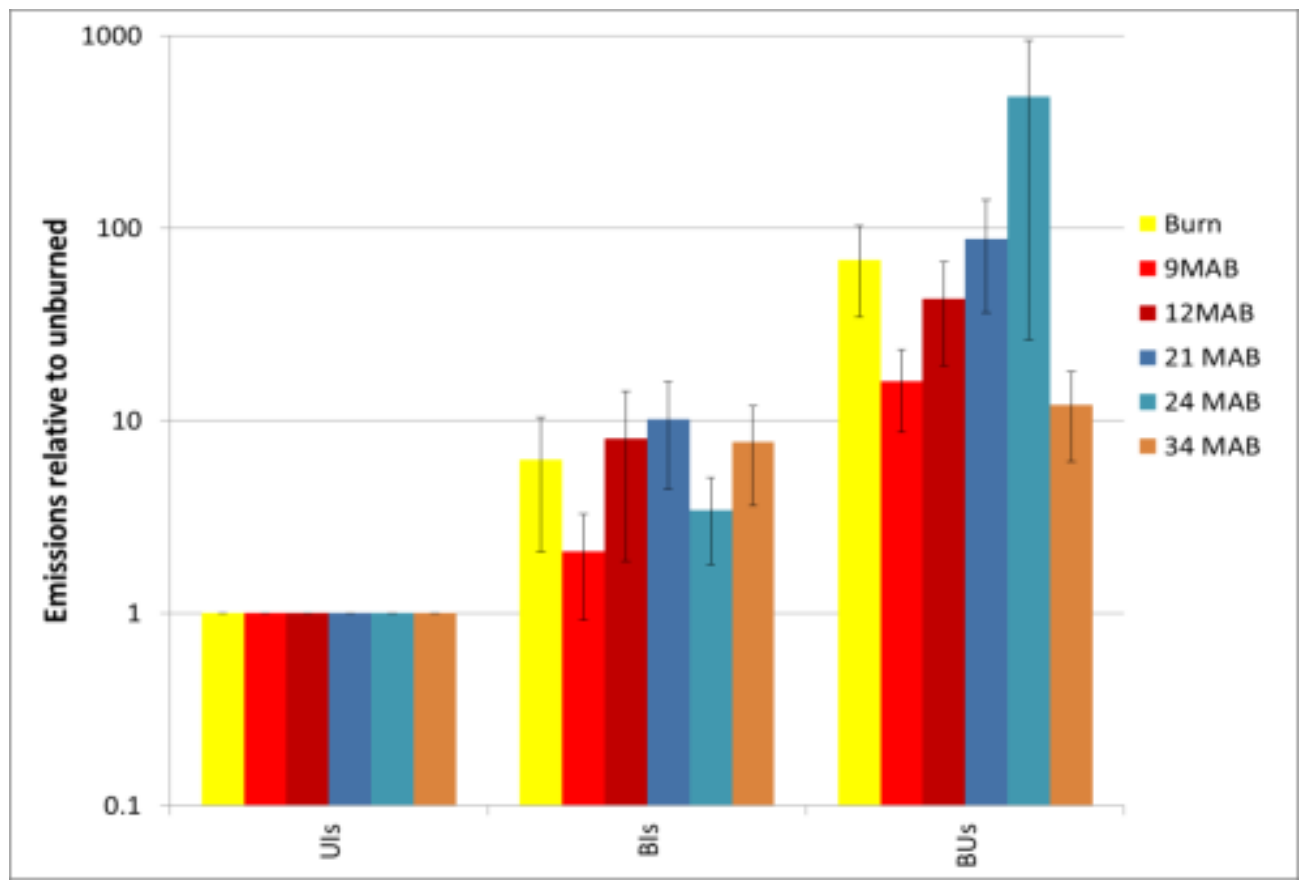

Figure 5. PI-SWERL results, normalized to unburned control area unburned soils. B=burned, $\mathrm{U}=$ unburned, Is $=$ interspace soil, Us = understory soil.

It was evident that $\mathrm{PM}_{10}$ emissions from the burned soil surfaces at the Gleason Fire site were greater than $\mathrm{PM}_{10}$ from associated unburned control areas throughout the monitoring period. Additionally, while somewhat more variable, $\mathrm{PM}_{10}$ from the burned understory soils was greater than $\mathrm{PM}_{10}$ from the burned interspace soils - again, throughout the monitoring period. Emissions from both burned soil sites showed high initial emissions ("Burn"), which decreased at 9 MAB. By $12 \mathrm{MAB}$, emissions increased to "Burn" levels and, in the case of burned interspace, remained so throughout the study period. Only at $34 \mathrm{MAB}$ did $\mathrm{PM}_{10}$ from burned understory soils decrease to levels comparable to those from burned interspace soils, but both were still nearly an order of magnitude higher than $\mathrm{PM}_{10}$ from unburned soils. The amount of $\mathrm{PM}_{10}$ on burned soils remained significantly elevated from those of unburned soils throughout the 34-month study period at the Gleason Fire site.

The ratios of $[\mathrm{EC}]$ to [Soil] ([EC]/[Soil]) at the Gleason Fire site are shown in Figure 6. If Burned $[\mathrm{EC}] /[$ Soil] is greater than that for unburned soils, this implies that there are higher concentrations of [EC] in the burned compared to unburned soil. Burned soil [EC]/[Soil] less than that for unburned soil implies that there is less [EC] and more [Soil] in the burned $\mathrm{PM}_{10}$ than in unburned $\mathrm{PM}_{10}$. There was substantial scatter in the Gleason Fire [EC]/[Soil] data, even for unburned conditions, and the chemical signature of the burn was tenuous due to measurement uncertainty. For example, [EC]/[Soil] for the pre-burn measurements should be near zero as no or little [EC] was expected to have been present in the soil prior to the fire. Nevertheless, it was clear that immediately after the burn, $[\mathrm{EC}] /[$ Soil $]$ for both the plant interspace and understory burned soils were elevated with respect to the ratio on the unburned soils. This trend extended to $9 \mathrm{MAB}$ for the interspace soil. However, by $12 \mathrm{MAB},[\mathrm{EC}] /[$ Soil $]$ for the interspace soils was considerably lower than for the unburned soils, indicating the possibility that [EC] traces from the 


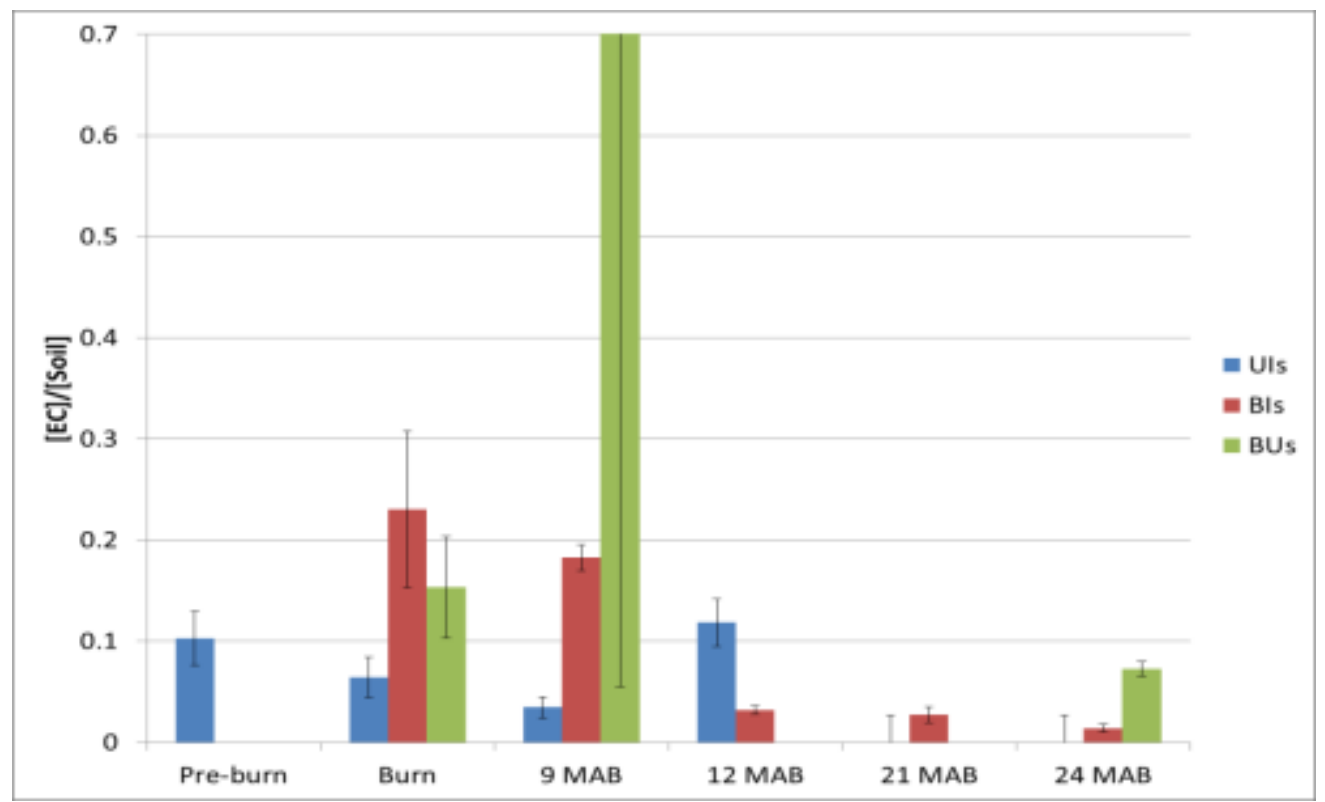

Figure 6. Ratio of elemental carbon ([EC]) to mineral soil ([Soil]) from $\mathrm{PM}_{10}$ filter samples collected during different field measurements. $\mathrm{B}=$ burned, $\mathrm{U}=$ unburned, Is = interspace soil, Us = understory soil.

fire were essentially depleted from interspace soils. Owing to excessive filter loading, understory samples collected at $12 \mathrm{MAB}$ could not be analyzed for soil constituents, and data for $34 \mathrm{MAB}$ were unavailable. Similarly, excessive loading for the $9 \mathrm{MAB}$ understory filter samples renders that $[\mathrm{EC}] /[$ Soil] data questionable. Nevertheless, with some adjustments to the collection methodology, the $[\mathrm{EC}] /[$ Soil] may prove useful as an indicator of the source of material in the airborne particulate material.

Overall, based on nearly three years (34 months) of periodically collected data, emissions of particulate material (wind erosion) from the Gleason Fire site do not appear to have returned to unburned wind erosion levels. Chemical composition data are quite variable, showing a definite increase in [EC] on burned as compared to unburned soils after the fire, but that emission component may have decreased by $12 \mathrm{MAB}$ and [Soil] may have increased subsequently. Nevertheless, it is clear that emission abundance from burned soils at the Gleason Fire site have remained elevated compared to unburned soils there, especially at vegetation understory soil sites.

\section{POST-FIRE SOIL AND RUNOFF PROPERTIES AND THE POTENTIAL FOR EROSION BY WATER}

\section{Methods}

Wildfires are often associated with the onset of the rainy season in the western U.S. The conjunction of these events can result in severe erosion leading to surface geomorphological changes (rills and gullies) and substantial sediment movement. Generally, it is recognized that elevated sediment yields are associated with the first intense post-fire rainfall and runoff events, 
and that sediment discharge rates return to pre-burn levels within two to three years (Berli et al., 2008). However, the specific characteristics of post-burn soil erosion, runoff, and sediment discharge are not well-documented for sites particular to the NNSS. Therefore, data were gathered from the Gleason Fire site, a site analogous to the vegetation community of the northern NNSS, to measure the physical effects of fire on soil, runoff, and sedimentation. The ultimate objective is to better understand the characteristics and persistence of post-fire soil erosion due to water.

\section{$\underline{\text { Soil Measurements }}$}

Changes in post-fire runoff regimes can be related to the many alterations in fire-affected soils, such as hydrophobicity and structural changes (Neary et al., 2005). Soils frequently exhibit some degree of water repellency or hydrophobicity after a burn. Hydrophobicity - the degree to which water remains on the soil surface and does not enter the soil-is a subtle and complex phenomenon (believed to be due to the burning of organic material) that appears to diminish over time, but is considered a feature that may contribute to increased post-burn runoff (DeBano, 2000). Hydrophobicity would then imply an increased potential for runoff, with the overlying ash layer being a potential source of sediment. Additionally, experimental evidence suggests the rate of change in soil temperature during a fire can destroy soil aggregates (Albalasmeh et al., 2013) eliminating pathways for water to enter the soil, also resulting in increased runoff. During each field visit, several soil properties were measured either in the field or in the laboratory from collected samples. Field measurements included ash cover, hydrophobicity, infiltration, and air pressure and flow through the soil. Saturated hydraulic conductivity $\left(\mathrm{K}_{\mathrm{s}}\right)$ was calculated from in situ infiltration measurements, and air permeability was calculated from in situ air pressure and flow measurements. Bulk density, porosity, organic matter (percent by weight), and particle size distribution were derived from laboratory analyses of samples collected at the fire site. All measurements were made at or near each infiltration measurement.

Infiltration was measured using eight modified Decagon mini disk tension infiltrometers (MDTI). Each infiltrometer consists of a clear reservoir tube topped with a Mariotte tube from which the tension of water supplied to the soil can be precisely controlled. The water is supplied to the soil through a sintered metal plate at the base of the tube. Modifications to the MDTI tube include increasing the supply reservoir from approximately 90 milliliters $\left([\mathrm{ml}], 5.49 \mathrm{in}^{3}\right)$ to $300 \mathrm{ml}$ $\left(18.31 \mathrm{in}^{3}\right)$ and adding a differential pressure transducer connected to a datalogger (Figure 7). Infiltration from all eight infiltrometers was measured simultaneously and recorded at five second intervals, as were additional parameters such as soil and supply water temperature. Infiltration at three tensions was measured: $-6.0 \mathrm{~cm}(-2.36 \mathrm{in}),-3.0 \mathrm{~cm}(-1.18 \mathrm{in})$, and $-0.3 \mathrm{~cm}(-0.12 \mathrm{in})$. Infiltration at each tension was allowed to proceed for a minimum of 20 minutes. For sites where infiltration was fast and the tube emptied before 20 minutes, the tube was refilled at the same tension and reapplied to the soil surface. When the tension was changed, the tube was usually refilled with water and then reapplied to the soil surface. The time of each tension change was noted for later analysis. 


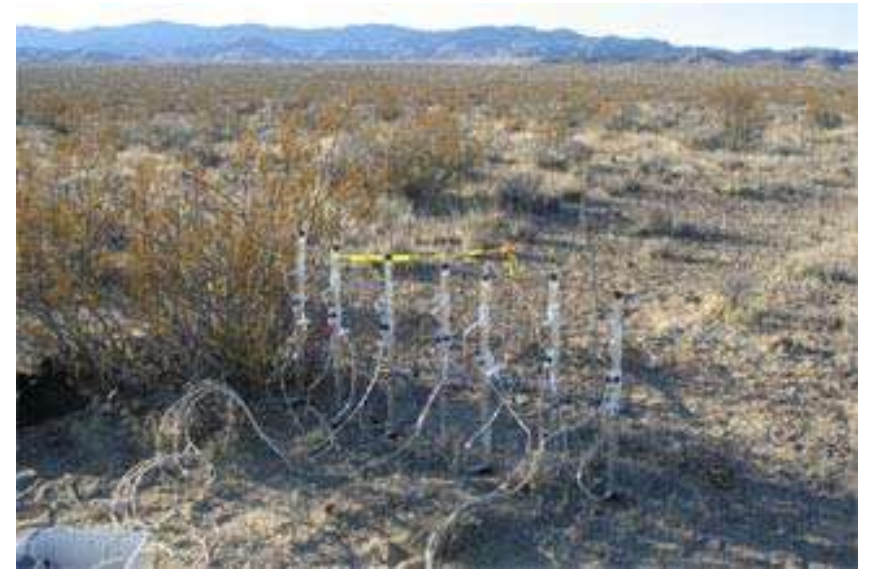

Figure 7. Set of eight modified MDTIs linked to a datalogger.

The determination of in situ saturated hydraulic conductivity $\left(K_{s}\right)$ is detailed in Caldwell et al., (2008). The methodology is based on a relationship established by Wooding (1968), which relates infiltration rate from an unconfined circular source to hydraulic conductivity:

$$
Q(\psi)=\pi r^{2} K(\psi)\left[1+\frac{4 \lambda_{c}}{\pi r}\right]
$$

where $Q(\psi)$ is the steady state infiltration, $r$ is the infiltrometer base radius, $K(\psi)$ is the hydraulic conductivity at tension $\psi$, and $\lambda_{c}$ is the macroscopic capillary length. The solution assumes a dry, homogeneous, and uniformly unsaturated soil. The relationship between $K(\psi)$ and $K_{s}$ is described by the exponential Gardner function:

$$
K(\psi)=K_{s} \exp (\alpha \psi), \quad \psi<0
$$

where $\alpha$ represents the ratio of gravity to capillary forces during infiltration and is equal to $\lambda_{c}^{-1}$. Large $\alpha$ values indicate dominance of gravity over capillary forces and occurs in coarse-textured and/or structured porous media. Similarly, small $\alpha$ values occur when capillary forces dominate gravity in fine-textured soils and/or structured media. Reynolds et al. (2002) show that the above equations can be solved for $K_{s}$ given a steady state infiltration rate and infiltrometer geometry using a single infiltrometer at multiple tensions. A nonlinear least-squares regression using an iterative solution method was used to determine $K_{s}$ and $\alpha$ for the measured infiltration data at the specified tensions.

Air permeability $\left(k_{\mathrm{a}}\right)$ describes the ability of air to move through the soil and gives indirect information about the hydraulic properties and structure of the soil. This may be an important property on fire-affected soils, especially if hydrophobicity inhibits water flow measurements. Several designs exist for field-based air permeameters; however, none are suitable for use in dry gravelly desert soils. Based on a design developed by Chief (Chief et al., 2006), a soil air 
permeameter for field assessment was used that, for the given geometry, required two measurements - $Q$ (the measured air flow rate) and $P$ (the measured pressure) - and, with minimal processing, quickly yielded values for air permeability.

Assuming that the $k_{a}$ is equal to the intrinsic air permeability under relatively dry conditions, the Darcian air flux density, $q$, is calculated as:

$$
q=-\frac{k_{a}}{\eta}\left(\frac{d P}{d z}+\rho g\right)
$$

where $\eta$ is the dynamic viscosity of air, $P$ is the sum of the change in pressure (over a distance), $z$ is depth, $\rho$ is the fluid density, and $g$ is the acceleration due to gravity. Because gases have a very low density, the gravitational term, $\rho g$, is less than one percent of the pressure term and thus negligible (Springer et al., 1995), so Eq. (1) can be simplified to:

$$
q=-\frac{k_{a}}{\eta}\left(\frac{d P}{d z}\right)
$$

The flux can be expressed as the flow, $Q$, per unit area perpendicular to the flow area, $A_{s}$, through a path length, $L$. The pressure gradient can be defined using the pressure difference between the inlet and outlet of a permeameter, $P_{i}$ and $P_{o}$. Solving for $k_{a}$ for a given soil column height, $\mathrm{H}$, yields:

$$
k_{a}=\frac{Q \eta}{A_{s}} \frac{H}{\left(P_{i}-P_{o}\right)}
$$

For in situ $k_{a}$ measurements, the outflow pressure is higher than atmospheric, and air only reaches atmospheric pressure after flowing back up to the soil surface. As a result, the path length over which the pressure decreases from the inlet pressure to atmospheric pressure is not equal to the inserted height of the column, $H$. The effects of divergent flow beyond the outflow end of an inserted air permeameter are addressed by assuming that the flow paths are the same for all measurement conditions, allowing for the introduction of a constant shape factor, $A$, which is defined as $A_{s} / L$, reducing Eq. (3) to:

$$
k_{a}=\frac{Q \eta}{A \Delta P}
$$

For in situ measurements, the shape factor is estimated based on the permeameter diameter and height of insertion into a homogeneous and isotropic medium (valid for diameter to height ratio less than 10) as:

$$
A=A_{\text {Jalbert }}=D\left(\frac{\pi}{4}+\frac{D}{H}\right)\left(1+\frac{D}{H}\right)^{-1} \ln \left(1+\frac{D}{H}\right)
$$

where $D$ is the diameter of the ring (Jalbert and Dane, 2003). 
Hydrophobicity was assessed using the Water Drop Penetration Time (WDPT) test (Doerr, 1998) where the ponding time of three drops of distilled water on the soil surface were averaged (Table 1). If present, the depth of the ash cover over the mineral soil surface was measured and recorded. Ash is hydrophilic (absorbs water), so it was brushed away prior to the WDPT test. Bulk density $\left(\rho_{b}\right)$ and porosity $(f)$ were measured from field samples of known volumes. Bulk density is equal to:

$$
\rho_{b}=M_{s} V_{t}^{-1}
$$

where $M_{s}=$ mass of oven dried soil, and $V_{t}=$ total volume of the dry soil. Also, porosity is equal to

$$
f=1-\frac{\rho_{b}}{\rho_{s}}
$$

where $\rho_{s}=$ the mean particle density of the soil particles, which for quartz, is generally estimated as $2.65 \mathrm{~g} \mathrm{~cm}^{-3}$ (166.57 pounds per cubic foot, lbs $\mathrm{ft}^{-3}$ ). Organic matter content (OM) was determined by the loss-on-ignition method (Powell et al., 1989), and the particle size distribution (thus, soil texture) was determined by a laser light scattering technique (ASTM, 2000).

Because the Gleason Fire was a prescribed fire, several soil sampling sites were established prior to the fire, then were resampled immediately following the fire (i.e., days before and after the fire) (-0.13 and 0.16 MAB, respectively); nearby sites were sampled at 10, 12, 22, 25, and $34 \mathrm{MAB}$. The results of the initial pre- and post-fire sampling are presented in Chief et al. (2012). Soil measurements were made on understory soils and interspace soils in both burned and unburned areas. Five linear soil sampling arrays were established in burned areas, and two in unburned areas during each field visit, comprising a 56-point transect of approximately $100 \mathrm{~m}$ (328.08 ft) each visit (Appendix B and Appendix C).

\section{Runoff Simulation and Measurements}

Standard methods to predict runoff and sedimentation are not applicable to many arid and semi-arid watersheds due to the lack of data. Watersheds that do have runoff data usually have short periods of record and many periods of no flow. Associated sediment data are even scarcer. Efforts to obtain the data are logistically difficult, if not impossible because fires themselves are unpredictable, as is the location, timing, and intensity of rainfall that leads to runoff. However, small-sized rainfall simulators can be used to provide realistic, site-specific rainfall, runoff, and sediment data from which to begin to understand watershed response. Runoff simulators are designed to determine the runoff and infiltration properties of field soils under specified rainfall inputs and non-ponded conditions.

A parameter important to some watershed modeling methods is the initial abstraction $\left(I_{a}\right)$ and infiltration loss of precipitation. Initial abstraction is the amount of precipitation that initially infiltrates into the soil prior to the occurrence of any runoff. Most rainfall-runoff models do not directly account for $I_{a}$ and infiltration losses, and rely on precipitation loss components that are considered to be sub-basin or overland flow area averages. The Soil Conservation Service (SCS) (now Natural Resource Conservation Service [NRCS]) Curve Number (CN) approach 
(U.S. Department of Agriculture [USDA]-SCS, 1986) is commonly used to account for precipitation losses and is recommended by the Clark County (Nevada) Regional Flood Control District (CCRFCD) (1999). This method for estimating rainfall excess was developed from studies of natural rainfall and runoff from small agricultural watersheds of less than 4 hectares [(ha), 10 acres (ac)] in the midwest and southeast United States (USDA-SCS, 1986), where the method has been shown to produce reasonable results. A drawback to the SCS CN approach is the assumption that one $\mathrm{I}_{\mathrm{a}}$ value is appropriate for precipitation events for all return periods because this may not be correct.

The SCS method relates the drainage characteristics of soil groups to a CN (USDA-SCS, 1986). This relation is based on soil group classification, vegetation cover, land use type (urban, agricultural, or desert), and antecedent moisture conditions based on the amount of rainfall in the prior five to 30 days. Curve numbers range from 100, which represents a completely impervious surface with decreasing $\mathrm{CNs}$ for more permeable surfaces. For example, a typical $\mathrm{CN}$ for asphalt pavement is 98 , whereas a $\mathrm{CN}$ for a golf course may be 61 or less. In a typical application, local regulatory agencies or SCS guidance is required for $\mathrm{CN}$ selection. However, if runoff volume, precipitation volume, and $\mathrm{I}_{\mathrm{a}}$ are measured or determined from measured data, a $\mathrm{CN}$ can be directly calculated.

The total depth of runoff from a storm is related to a $\mathrm{CN}$ by the following equations:

$$
Q=\left\{\frac{\left(P-I_{a}\right)}{\left[\left(P-I_{a}\right)+S\right]}\right\}
$$

where $Q$ is runoff volume, $P$ is precipitation volume, $I_{a}$ is initial abstraction, and $S$ is the potential maximum retention of precipitation in the soil after runoff has begun (as runoff occurs, some infiltrated precipitation is retained in the soil). $S$ is related to $I_{a}$ as:

$$
S=\frac{I_{a}}{0.2}
$$

The $\mathrm{CN}$ is then calculated as follows:

$$
C N=\frac{1000}{(S+10)}
$$

The portable rainfall simulator used for this study consisted of a flat Plexiglas reservoir (61 cm x $61 \mathrm{~cm}, 24$ in x 24 in) for water with hypodermic needles on the underside (Mutchler and Moldenhauer, 1963; Munn and Huntington, 1976; Miller and French, 2001). Water drops were produced on the needles by providing a constant gravity head, wetting a $3,612 \mathrm{~cm}^{2}\left(600 \mathrm{in}^{2}\right)$ area directly beneath the rainfall simulation (Figure 8 ). Rainfall simulator measurements were conducted at rates of approximately 4.17 centimeters per hour $\left(\left[\mathrm{cm} \mathrm{hr}^{-1}\right], 1.70\right.$ inches per hour $\left.\left[\mathrm{in} \mathrm{hr}{ }^{-1}\right]\right)$, simulating the maximum intensity of a one-hour, 100-year storm, as per the National Oceanic and Atmospheric Administration (NOAA) Atlas 14 (NOAA-National Weather Service, 2004) for the area. Rainfall simulations lasted one hour. 
To sample total runoff and sediment, a small trough was entrenched just downslope of the footprint of the rainfall simulator. A piece of PVC pipe, sliced lengthwise and capped at both ends, was placed in the trough with a 90-degree-bend aluminum flashing installed over the trough lip to collect the flow. If flow occurred during the simulation, water collected in the trough was sampled for 30 seconds every five minutes, and the volume recorded. Runoff sampling was stopped at the end of the one-hour simulation. The runoff samples were sent to a laboratory to determine suspended sediment concentration and particle size distribution.

The rainfall simulator was calibrated before and after each rainfall simulation experiment to ensure that the application rate was approximately at the target rate and to evaluate any drift from the initial rate. This was accomplished by placing a Plexiglas plate under the simulator and collecting the output at three one-minute increments before each test. The depth of the collected output was measured in a graduated cylinder to determine the rainfall rate. Without flow interruption, the plate was quickly removed and the experiment was started. At the end of the experiment, again without flow interruption, the Plexiglas plate was inserted back under the simulator and, as before, the output was captured for at least one one-minute increment. These initial and post-calibration rates were averaged and used as the application intensity in calculations to determine infiltration properties.

After the initial calibration measurements, the experimental precipitation event was started on the test surface, during which four time readings were taken: (1) when initial ponding occurred anywhere on the surface test plot, (2) when initial runoff occurred anywhere on the surface test plot, (3) when runoff occurred in each quadrant of the surface test plot, and (4) when initial runoff reached the collection trough. A "pre-rainfall" (dry) soil sample was collected adjacent to each test plot before the test and a soil sample was collected from the center of each test plot after one-hour of rainfall simulation. The sampled runoff hydrographs, if runoff occurred, are included in Appendix D. Soil moisture was recorded throughout the rainfall simulation and the amounts appear in Appendix E. The gravimetric (by weight) soil moisture content, bulk density, and porosity was determined from these samples. Again, the particle size distribution of sediment was determined by a laser light scattering technique (ASTM, 2000).

Rainfall simulator sites were sampled at 10, 12, 22, 25, and $34 \mathrm{MAB}$, and were within $100 \mathrm{~m}(328.08 \mathrm{ft})$ of the soil transects, in areas undisturbed by previous sampling. Nine rainfall simulator sites were established each field visit: three each on burned interspace and burned understory soils, and three in unburned interspace soils. Plant cover prevented the placement of the rainfall simulator on unburned understory soils. 


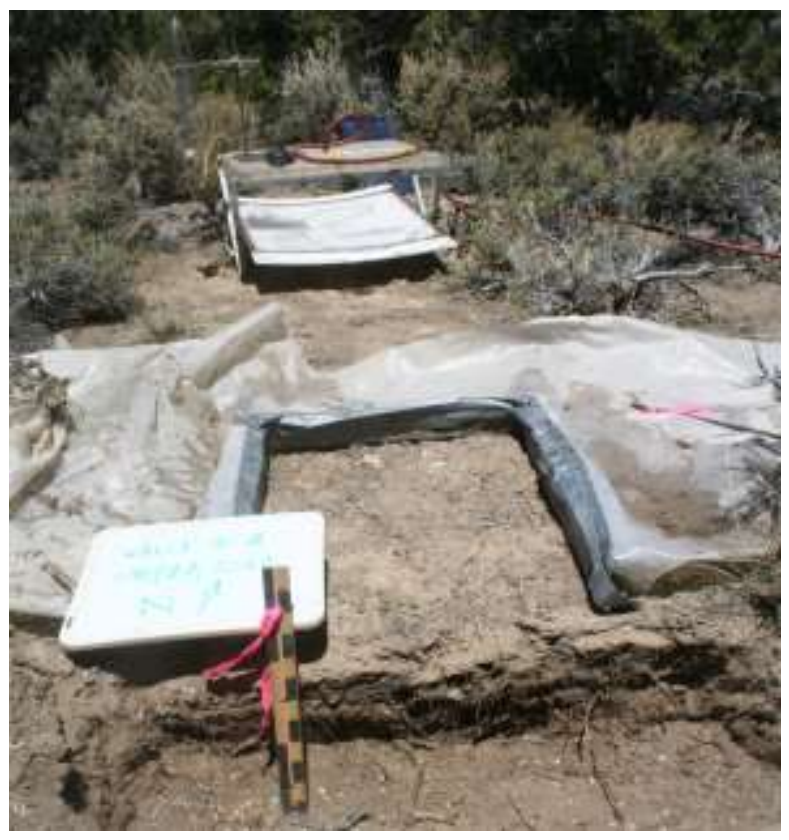

Figure 8. Photograph of portable rainfall simulator (background) before installation over area to be sampled (foreground). The Plexiglas plate beneath the simulator is for rainfall collection for calibration. Trench for collection trough at the downstream side of plot is also shown.

\section{Results}

Soil Properties and Hydraulic Characterization

Hydrophobicity was assessed using the WDPT test (Doerr, 1998; Schoeneberger, et al., 2012) where the ponding time of three drops of distilled water on the soil surface were averaged (Table 1). The data were highly variable, but little or no hydrophobicity (ponding time greater than 60 seconds) was evident on unburned or pre-burned soil. Immediately after the burn, burned understory soils exhibited a slight degree of hydrophobicity [60-180 seconds (sec)], increasing to moderately hydrophobic $(180-600 \mathrm{sec})$ by $10 \mathrm{MAB}$. At $12 \mathrm{MAB}$, both burned interspace and understory soils showed slight $(5-60 \mathrm{sec})$ hydrophobicity. After $12 \mathrm{MAB}$, there was no evidence of soil hydrophobicity throughout the sampled area, nor at any other time. No ash existed on pre-burned soils, but was greater over understory soils than over interspace soils after the burn. The depth of ash over fire-affected soil decreased with time. The amount of organic matter in the soil was greater in understory soils than interspace soils, but the organic matter content in the soils generally seemed unaffected by the burn as the amount did not vary appreciably between burned and unburned soils, thus suggesting a low intensity fire. Bulk densities for burned soils were lower than for unburned soils indicating the burned soils were less dense than unburned soils. This effect may indicate fire has structural effects on the soil.

Porosity, $\mathrm{K}_{\mathrm{s}}$, and $\mathrm{k}_{\mathrm{a}}$ - soil properties important for understanding water infiltration and runoff - are considered temporally constant (under normal conditions), so differences over time would be due to location (understory or interspace), treatment (burned or unburned), or other soil processes. For both burned and unburned soils, average understory soil porosity was greater than 
Table 1. Averages and coefficients of variation* (in parenthesis) for selected soil parameters from the Gleason burn site (2009-2012); " $\mathrm{n} / \mathrm{a}$ " indicates data are not available. MAB = months after burn; WDPT $=$ water drop penetration time; $\mathrm{OM}=$ organic matter; $\mathrm{BD}=$ bulk density. $-0.13 \mathrm{MAB}$ indicates a sample date four days before the fire, 0.16 indicates a sample date five days after the August 13, 2009 fire.

\begin{tabular}{|c|c|c|c|c|c|c|c|}
\hline Description & MAB & Site & $\begin{array}{c}\text { No. of } \\
\text { samples }\end{array}$ & $\begin{array}{l}\text { WDPT } \\
(\mathrm{sec})\end{array}$ & $\begin{array}{l}\text { Ash } \\
(\mathrm{cm})\end{array}$ & $\begin{array}{c}\text { Soil OM } \\
(\%)\end{array}$ & $\begin{array}{c}\mathrm{BD} \\
\left(\mathrm{g} \mathrm{cm}^{-3}\right)\end{array}$ \\
\hline \multirow{2}{*}{$\begin{array}{l}\text { Pre-burn } \\
\text { (immed.) }\end{array}$} & -0.13 & understory & 20 & 0 & 0.0 & $3.54(24)$ & $1.36(13)$ \\
\hline & -0.13 & interspace & 20 & 0 & 0.0 & $2.62(11)$ & $1.57 \quad(6)$ \\
\hline \multirow[t]{2}{*}{ Post-burn (immed.) } & 0.16 & understory & 21 & 99 & 2.1 & $3.77(40)$ & $1.17(15)$ \\
\hline & 0.16 & interspace & 19 & 3 & 0.0 & $2.87(18)$ & $1.31(18)$ \\
\hline \multirow[t]{10}{*}{ Burned } & 10 & understory & 20 & 341 & 2.8 & $\mathrm{n} / \mathrm{a}$ & $1.26(11)$ \\
\hline & 12 & understory & 20 & 31 & 4.0 & $2.62(34)$ & $1.37(10)$ \\
\hline & 22 & understory & 20 & $\mathrm{n} / \mathrm{a}$ & $\mathrm{n} / \mathrm{a}$ & $3.50(16)$ & $1.42(13)$ \\
\hline & 25 & understory & 20 & 2 & 1.2 & $4.61(21)$ & $1.40(12)$ \\
\hline & 34 & understory & 20 & $\mathrm{n} / \mathrm{a}$ & $\mathrm{n} / \mathrm{a}$ & $3.70(13)$ & 1.32 (9) \\
\hline & 10 & interspace & 20 & 1 & $\mathrm{n} / \mathrm{a}$ & $\mathrm{n} / \mathrm{a}$ & $1.53(6)$ \\
\hline & 12 & interspace & 20 & 36 & 2.1 & $2.24(25)$ & $1.50(10)$ \\
\hline & 22 & interspace & 20 & $\mathrm{n} / \mathrm{a}$ & $\mathrm{n} / \mathrm{a}$ & $3.18(16)$ & $1.56 \quad(8)$ \\
\hline & 25 & interspace & 20 & 2 & 1.4 & $3.93(28)$ & $1.54(11)$ \\
\hline & 34 & interspace & 20 & $\mathrm{n} / \mathrm{a}$ & $\mathrm{n} / \mathrm{a}$ & $3.31(15)$ & $1.37 \quad(8)$ \\
\hline \multirow[t]{2}{*}{ Unburned } & (all) & understory & 48 & 2 & 0.0 & $2.88(36)$ & $1.42(13)$ \\
\hline & (all) & interspace & 48 & 2 & 0.0 & $2.46(34)$ & 1.53 \\
\hline
\end{tabular}

*Coefficient of variation $(\%)=[$ standard deviation/average $] \mathrm{x} 100$.

average interspace soil, likely due to current or pre-fire biointrusion (Figure 9a). Porosity on both burned interspace and burned understory soils was slightly greater than on comparable unburned soils, especially up to $12 \mathrm{MAB}$, which is consistent with bulk density data. Saturated hydraulic conductivity is an indicator of the infiltrability of the soil. Higher values indicate more infiltration; lower values indicate less infiltration, and therefore a higher potential for runoff.

Average $\mathrm{K}_{\mathrm{s}}$ values (Figure $9 \mathrm{~b}$ ) for unburned understory soils were greater than average values for unburned interspace soils, as expected. In burned areas, understory $\mathrm{K}_{\mathrm{s}}$ was greater than in burned interspace $\mathrm{K}_{\mathrm{s}}$ indicating some persistence of pre-burn vegetation on post-fire soil hydraulic properties, as was noted in the bulk density and porosity data. Due to variability in the data, there was no clear effect of fire on $\mathrm{K}_{\mathrm{s}}$ on understory soils, which is where any differences could be due to hydrophobicity, especially immediately after the fire. The range of $\mathrm{K}_{\mathrm{s}}$ on burned interspace soils are within the range of $\mathrm{K}_{\mathrm{s}}$ values from unburned interspace $\mathrm{K}_{\mathrm{s}}$ values, except at 

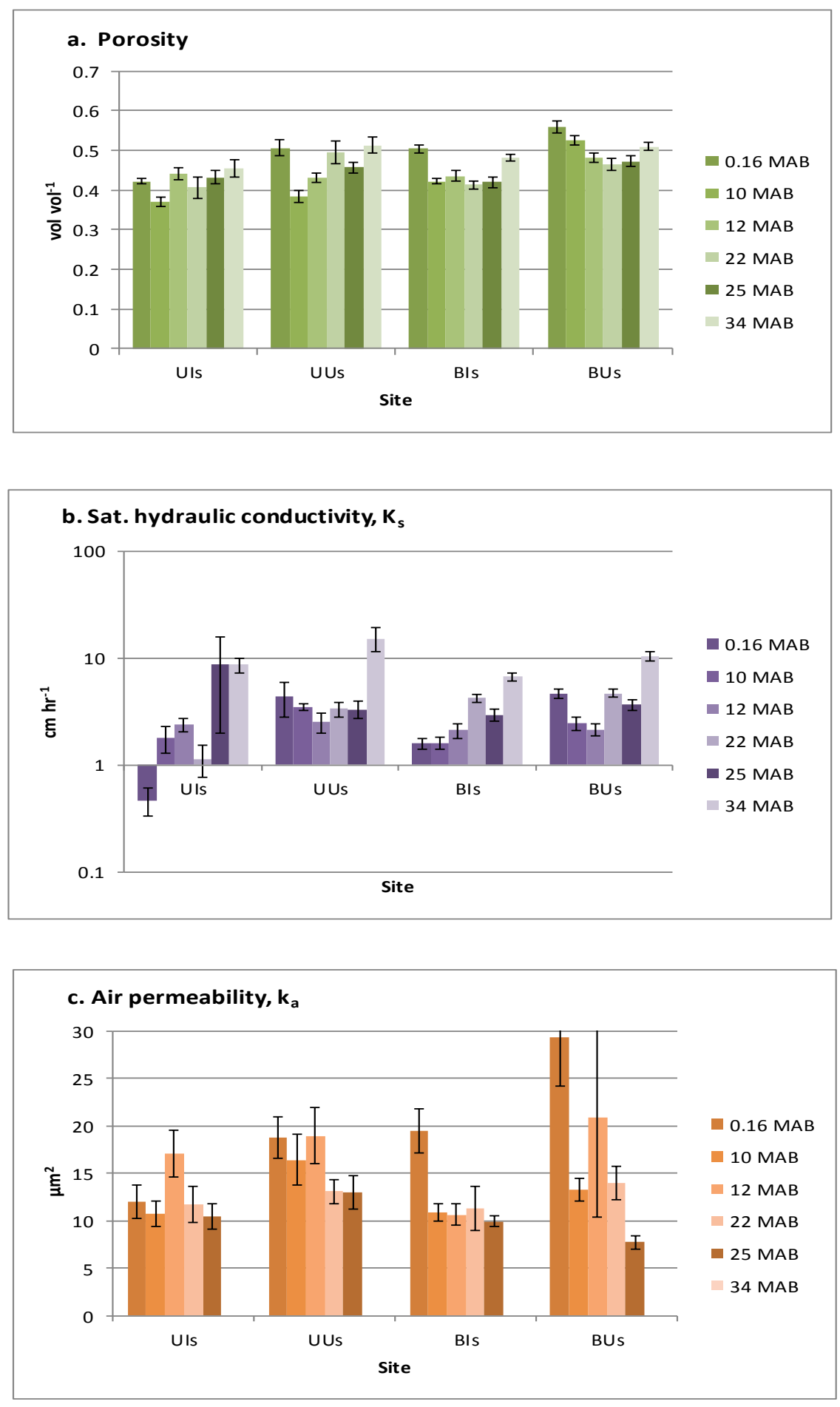

Figure 9. (a) Soil porosity, (b) saturated hydraulic conductivity, and (c) soil air permeability measured at the Gleason Fire site to 34 MAB, 2009-2012. There were eight samples for each data bar representing unburned sites and 20 samples for each data bar representing burned sites for each time period. Error bars show standard error (standard deviation $\mathrm{x}$ no. of samples ${ }^{-1 / 2}$ ). $\mathrm{B}=$ burned, $\mathrm{U}=$ unburned, $\mathrm{Is}=$ interspace soil, Us $=$ understory soil. 
$25 \mathrm{MAB}$ where burned interspace $\mathrm{K}_{\mathrm{s}}$ are lower than $\mathrm{K}_{\mathrm{s}}$ from unburned interspace soils. High $\mathrm{K}_{\mathrm{s}}$ values at $34 \mathrm{MAB}$ appear anomalous.

The $\mathrm{k}_{\mathrm{a}}$ response over time in burned soils was similar to porosity, in that $\mathrm{k}_{\mathrm{a}}$ values peaked immediately following the fire and then gradually decreased, which is consistent with the bulk density data. The $\mathrm{k}_{\mathrm{a}}$ for understory soils was greater than for interspace soils. Both burned understory and burned interspace $\mathrm{k}_{\mathrm{a}}$ values appear to have converged to near average unburned interspace $\mathrm{k}_{\mathrm{a}}$ values by $22 \mathrm{MAB}$. Air permeability data from 34 MAB were unavailable do to instrumentation failure.

Chief et al. (2012) examined the soil texture and structure both before and immediately after the burn (-0.13 and 0.16 MAB, respectively). Using U.S. Department of Agriculture particle size classes (Gee and Or, 2002), Gleason soils were classified as sandy loams with clays (particles less than $2 \mu \mathrm{m}, 0.00008$ in) constituting approximately 10 percent or less by weight of the upper 0 $8 \mathrm{~cm}(0-3.1 \mathrm{in})$ soil. In addition, the soil structure deteriorated from a strong, definable pre-burn structure to a weakly cohesive, massive unstructured surface soil immediately after the burn (Figure 10). The change in structure may be due to the expansion of vaporized water in the soil pores that would have destroyed flow paths, and altered air and water flow properties as indicated by Albalasmeh et al. (2013).

A difference in surface soil structure between burned and unburned areas was noted during later field visits. The unburned soil surface exhibited crusts separated by cracks, which could contribute to increased infiltration in the unburned areas. Therefore, at $34 \mathrm{MAB}$, a Humboldt $\mathrm{H}-$ 4212 MH Pocket Shear Vane Tester and a Geotester Pocket Penetrometer (both small, readily available instruments) were used to determine the soil surface strength. Each instrument provided a measure of the amount of force necessary to break the soil surface crust. It is important to note that while some soil surface crust formation was rarely observed in the burned interspace sites at $34 \mathrm{MAB}$, it was far more common in unburned interspace sites. No soil surface crust formation was observed at understory sites, whether burned or not. While the instruments applied stress to the soil surface in different ways (one was turned, the other pushed in vertically), the resultant readings for soil cohesion were remarkably close (Figure 11). The soil surface crust cohesion averaged approximately 129 kilopascals ([kPa], 18.7 pounds per square inch [psi]) at unburned interspace sites, significantly greater than the average of $65 \mathrm{kPa}(9.4 \mathrm{psi})$ on the burned interspace sites. For comparison, values commonly associated with raindrop impact and the PI-SWERL at $3,000 \mathrm{rpm}$ are $0.08 \mathrm{kPa}(0.01 \mathrm{psi})$ and $0.0003 \mathrm{kPa}(0.00004 \mathrm{psi})$, respectively (Julien, 1998; DUST-QUANT, 2008). These values are orders of magnitude lower than the observed cohesion due to soil surface crusting, but they provide an idea of how susceptible a soil surface consisting of cohesionless particles is to wind and water erosion immediately following a fire when the massive (unstructured and crustless) soil surface was observed.

\section{$\underline{\text { Runoff Generation, Sedimentation, and Curve Numbers }}$}

Runoff and sediment from the rainfall simulator experiments were scarce (a runoff experiment yielding no runoff was not uncommon) and variable (Appendix D). Runoff was low 


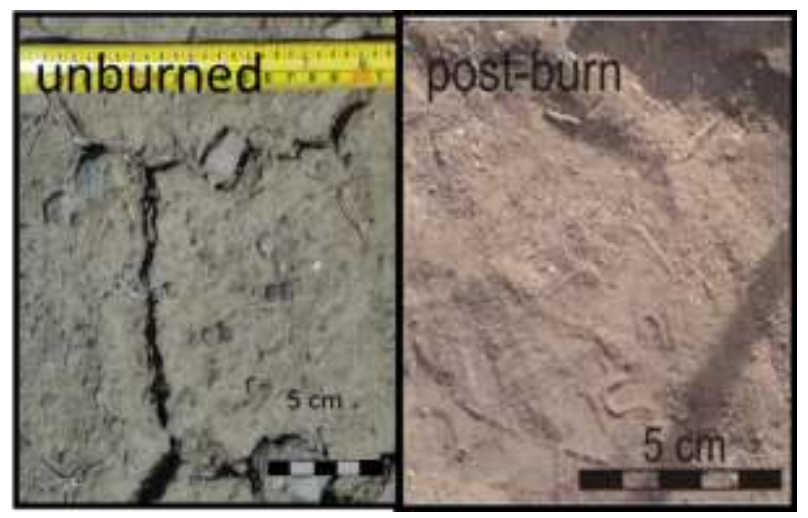

Figure 10. Surface soil structure at Gleason Fire site in unburned (left) and post-burn (right) conditions.

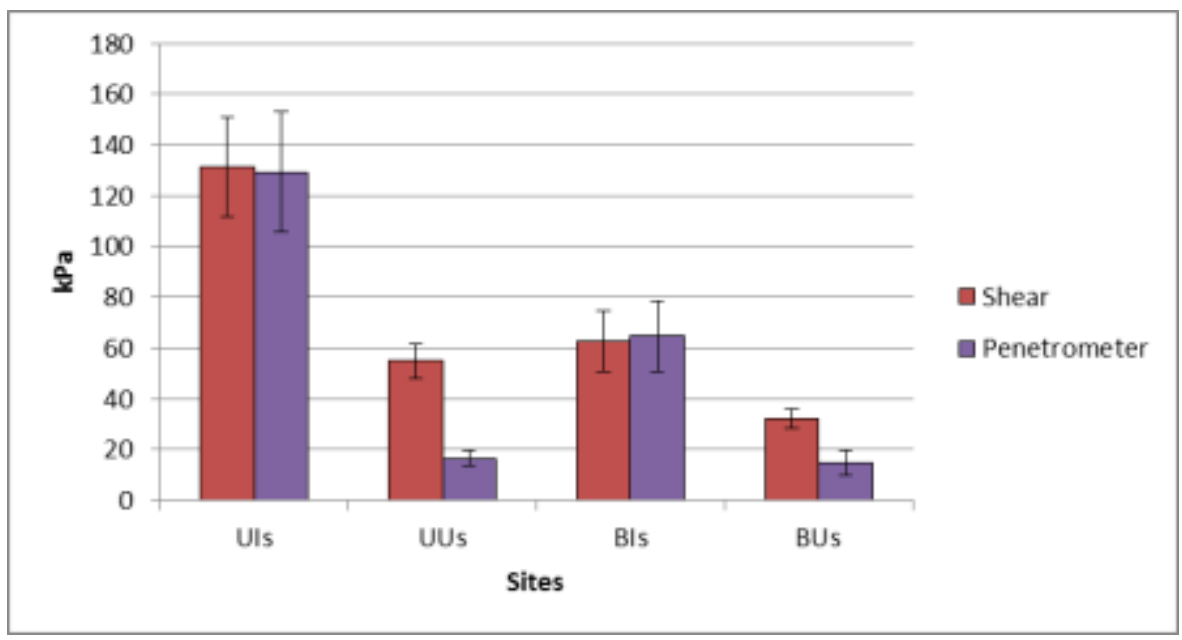

Figure 11. Measurements of soil surface strength expressed as cohesion at $34 \mathrm{MAB}$ using a shear vane tester and a pocket penetrometer. $\mathrm{B}=$ burned, $\mathrm{U}=$ unburned, Is = interspace, Us $=$ understory.

after the fire (Figure 12a). However, runoff was more frequent (frequency $=$ number of rainfall simulations producing runoff/number of rainfall simulations $=0.73$ ) on burned interspace plots than on burned understory (frequency $=0.47$ ) and unburned interspace (frequency $=0.50$ ) plots throughout the study period. Runoff on all nine simulator plots occurred only at 25 MAB. Runoff on burned interspace plots appeared only slightly elevated compared to unburned plots, but definitely higher than on burned understory plots. The concentration of sediment in the sampled runoff is shown in Figure 12b. The effect of fire on the average concentration of sediment is not discernible, but the occurrence of sediment-laden flow is highest on burned interspace plots and more frequent than on burned understory plots or on unburned plots. Although the fire did not appear to increase the amount of runoff or sediment per simulation, the frequency of runoff increased on burned interspace plots. The cumulative effect is an increase in the total amount of runoff and sediment over the three-year monitoring period on unburned interspace plots. 

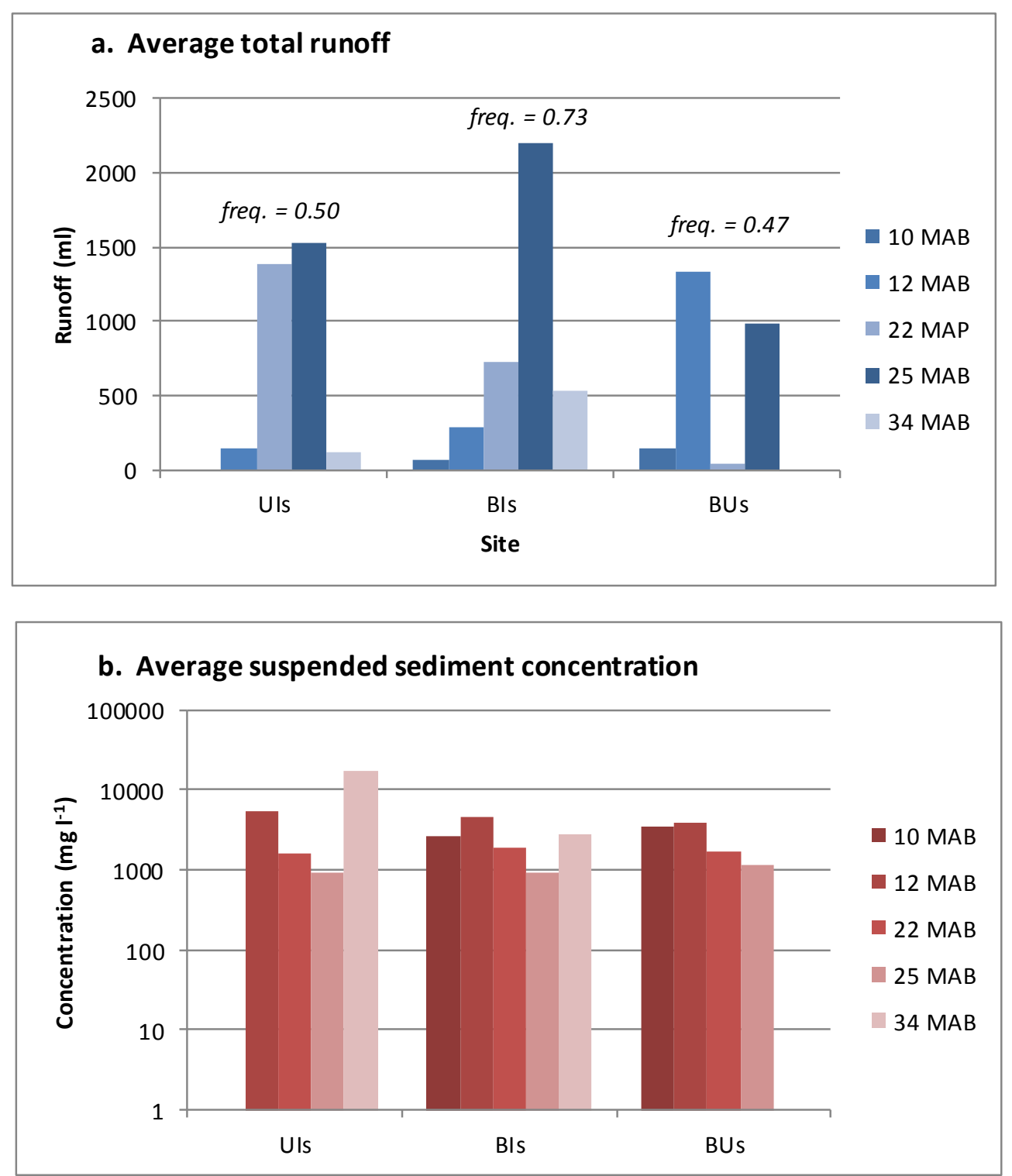

Figure 12. Total runoff volumes and frequency of occurrence for rainfall simulator at the Gleason Fire site to $34 \mathrm{MAB}$. Each bar represents an average of three replicates. B = burned, $\mathrm{U}=$ unburned, Is = interspace, and Us = understory.

The particle size distribution of sediment suspended in runoff was determined and the median particle diameter $\left(\mathrm{d}_{50}\right)$ for each sample was calculated (Figure 13). The particle size distribution of sediment diameters ranged from $0.01 \mu \mathrm{m}\left(3.9 \times 10^{-7}\right.$ in $)$ to $1,000 \mu \mathrm{m}(0.039 \mathrm{in})$. Although runoff, hence sediment, was infrequent, a pattern emerged. There was little difference evident in median particle sizes from interspace plots, whether unburned or burned, but these particles were relatively small $\left(\mathrm{d}_{50} \approx 10 \mu \mathrm{m}, 3.9 \times 10^{-4} \mathrm{in}\right)$. The sediment from burned understory 
soils was notably larger $\left(\mathrm{d}_{50} \approx 25 \mu \mathrm{m}, 9.8 \times 10^{-4}\right.$ in), but decreased logarithmically (coefficient of determination for regression $=\mathrm{R}^{2}=0.58$ ) to the median size of sediment from the other sites by $34 \mathrm{MAB}$. Thus, it appears coarser soil particles in sediment originated in burned understory areas. As more ash was measured on burned understory soils, this may have contributed to the larger sediment evident there, as was suggested by the PI-SWERL data.

Curve numbers, which represent precipitation losses, integrate several aspects of runoffrelated characteristics, such as land use, soil type, vegetative cover, soil surface condition, and soil moisture (Appendix E). Several measures of runoff initiation are measured each time the rainfall simulator is operated, including when ponding first occurs on the soil surface anywhere under the simulator, when any runoff occurs, when runoff occurs in all quadrants under the simulator, and when runoff into a downstream collection trough is first observed. A CN of 100 indicates a completely impervious surface; lesser values indicate progressively more permeable surfaces. These values can then be used to estimate watershed discharge-for example, using the HEC-1 and HEC-HMS models (U.S. Army Corps of Engineers, 2000)—or for design guidance, such as in the CCRFCD Hydrologic Criteria and Drainage Design Manual (CCRFCD, 1999). The use of the portable rainfall simulator under actual field conditions allows for the direct calculation of CNs.

From previous rainfall simulation studies performed on the NNSS, Miller and French (2001) determined that the most appropriate $\mathrm{CN}$ for each surface came from the time at which runoff was observed from all quadrants under the simulator. Curve numbers are listed in Appendix $\mathrm{F}$ and averaged values from all quadrant runoff measurements appear in Figure 14. Generally, the CNs were slightly higher on burned than unburned sites, with a slightly decreasing temporal trend at burned interspace sites. However, all CNs at all sites exhibited a slight seasonal pattern with lower average CNs at the beginning of the summer (10,22, and

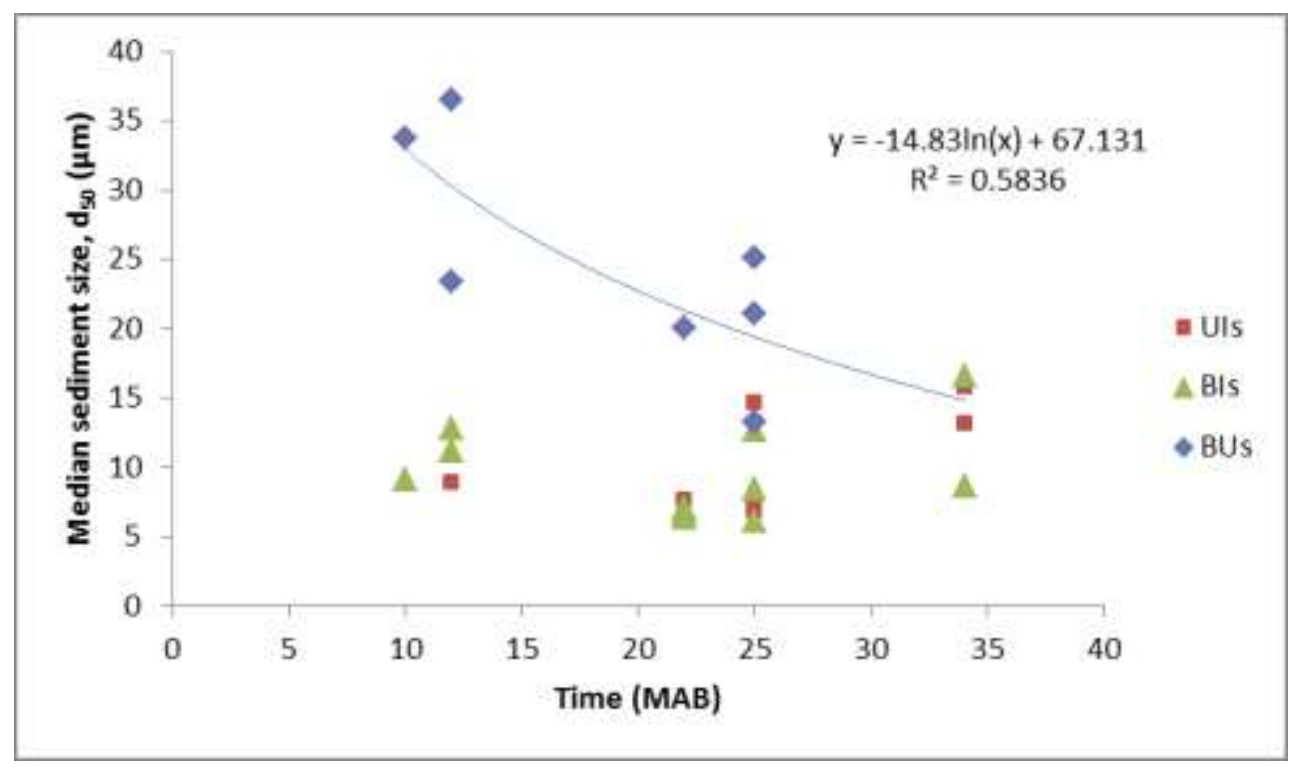

Figure 13. Median sediment size, $d_{50}(\mu \mathrm{m})$, for sediment sampled during rainfall simulation to 34 MAB. $\mathrm{B}=$ burned, $\mathrm{U}=$ unburned, Is = interspace, and Us = understory. 
$34 \mathrm{MAB}$ ) and higher average values later in the summer (at 12 and $25 \mathrm{MAB}$ ). The 34-month dataset is not long enough to establish this characteristic, but, if verified, has important fire management implications. While the water erosion potential may only appear slightly elevated, the timing of precipitation following a fire may intensify the runoff response.

The soil and runoff response to the Gleason Fire was monitored over a nearly three-year post-fire period. Data were periodically collected from both burned and comparable unburned areas. Soil hydrophobicity was detected at the site, but mainly on burned understory soils and to a moderate degree lasting up to $12 \mathrm{MAB}$. Soil bulk density and porosity in the burned areas were both higher than in unburned areas indicating that the fire may have made the soil less dense. The structure of the soil was altered by the fire and burned soil surface cohesion at $34 \mathrm{MAB}$ was lower on the unburned soils. Air permeability reflected the porosity and bulk density data. Overall soil hydraulic conductivity on burned interspace was variable, but slightly lower than on unburned interspace sites up to $25 \mathrm{MAB}$; it was, however, lower than on burned understory sites indicating a greater runoff potential on burned interspace soils. The relationship between soil hydraulic properties and runoff amounts at this site remains unclear. However, rainfall simulation data showed that increased runoff due to the fire was detectable in the increased frequency of runoff on burned interspace soils. This feature was also evident in sediment concentration indicating that the fire resulted not in more runoff or sediment per event, but in more frequent runoff events. Over the 34-month monitoring period, this would result in a total increase in runoff and sediment. This soilrelated fire response may be due to the structural changes in the soil and the immediate effect of soil hydrophobicity. Additionally, the median sediment size in runoff from burned and unburned interspace soils were similar and almost half the size of sediment from burned understory soils indicating that sediment, thus runoff, from

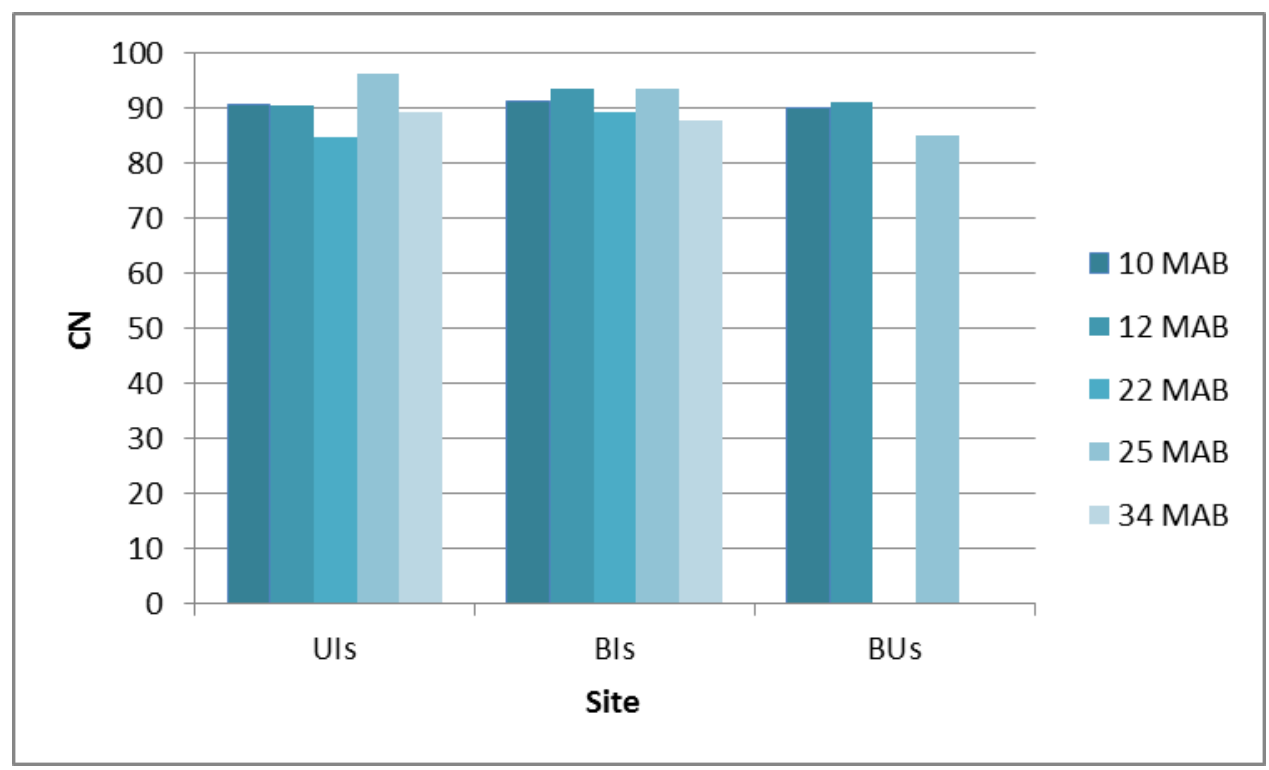

Figure 14. Curve numbers (CNs) calculated from all rainfall simulations (using All Quadrant Runoff data) at the Gleason Fire site to 34 MAB, 2009-2012. B = burned, U = unburned, Is $=$ interspace, and Us $=$ understory. 
understory burned areas was not contributing much to the post-fire runoff response. The sediment size from burned understory soils decreased to the same size as from other soils by 34 MAB. This result is in contrast to the wind erosion data that clearly indicates burned understory soils were the major source area for wind-borne particulate matter in the post-fire monitoring period. The CNs did indicate a relatively high potential for runoff and a possible seasonal component to runoff response at the site that may be an important consideration for runoff prediction and management. Overall, the differences in soil properties and between burned interspace and burned understory sites suggested the effect of vegetation on soil, and the subsequent effect on runoff and sediment persisted after the fire.

\section{POST-FIRE VEGETATION RESPONSE}

\section{Previous Surveys}

Data were collected previously in the Gleason burned area in 2010 and 2011. The data sheets and digital translation of those data were available to assist in locating the general area of data collection; however, the original survey area corners were not staked, and thus not readily relocated. The data sheets had two of four global positioning system (GPS) coordinate corner locations recorded from the previous surveys, but the locations of all four corners, needed to fully outline the area previously surveyed with precision, were not available. Two corners were not sufficient to re-locate the surveyed area because the documentation did not include a key to which side of the area (rectangle) they represented and no cardinal direction was recorded.

The previous survey method had been labeled as "transects," however in the field, they were delineated and surveyed as a long narrow plot(s) and surveys of these areas were conducted using a plot survey approach rather than a transect measurement approach. In addition, these "transect" areas were geographically continuous in their placement with no physical space between the survey areas. With no definable border from one to the next, they lacked spatial independence.

\section{Methodology for the Survey of Original "Transect" Plots, 2012}

Vegetation data were collected June 26-27, 2012, approximately three years after the burn. A long, thin plot $50 \mathrm{~m} \mathrm{x} 2.5 \mathrm{~m}(164.0 \mathrm{ft} \times 8.2 \mathrm{ft})$ was delineated in each of the two general areas of the burned landscape, which had been surveyed in previous years 2011 and 2010. This was done in an attempt to revisit the area previously surveyed to conduct multiple-date comparison of species composition and canopy cover. Two corner coordinates were recorded from GPS during previous surveys. The spatial accuracy of handheld GPS units tends to be \pm 3 to $4 \mathrm{~m}$ (9.8 to $13.1 \mathrm{ft}$ ), which is greater than the width of the survey area. The use of the GPS coordinates thus provided a means to navigate to a close approximation of the area surveyed, but because the original survey areas were not staked, the precise location of those plots/transects could not readily be re-established.

When survey area corner points were located, each corner was staked with a small metal stake and washer, hammered so as to be flush with the ground. The washer is useful for re-locating the stake if a metal detector is needed in the future. GPS coordinates of each corner of the plot were recorded and photographs of the area to be surveyed were taken. Metric tapes were used to outline the $\mathrm{X}$ and $\mathrm{Y}$ axes on all sides to expedite data collection.

The surveys were conducted by two-person teams, where one person recorded data on paper data sheets while the other established species identification, position within the plot, and size in three dimensions (length, width, height). The survey date was recorded as "Date" and the 
corresponding original survey date, either 2010 or 2011, was recorded as "Transect." Pagination was recorded as $\mathrm{X}$ of $\mathrm{Z}$ pages to maintain a complete record of all data collected, crew initials were recorded, and the origin coordinate of the survey area from GPS was recorded. The transect direction was measured using a Suunto compass and recorded as cardinal direction. End coordinate was not recorded, but was calculated for greater accuracy. Datum was recorded as NAD83.

Species was recorded in four letter code where the first two letters corresponded to the first two letters of the genus name and the second two letters correspond to the first two letters of the species name. Location within the plot $(\mathrm{X}, \mathrm{Y})$ was measured using a Cartesian coordinate system with 0,0 being the lower left corner and starting point for location. The plant location within the plot was recorded in meters. Three size measurements were recorded for each individual plant in units of cm: height, $\mathrm{C} 1$, and $\mathrm{C} 2$. The measurement $\mathrm{C} 1$ is the longest dimension of the plant canopy and $\mathrm{C} 2$ is the perpendicular length of the canopy relative to $\mathrm{C} 1$. The two measurements together are used to calculate canopy cover of the individual plant. Comments were recorded as necessary and appropriate.

In the few instances where species identification was in question, a sample of the plant was collected and placed in a plant press. Each sample was labeled and that label was used in the "species" line. The label incorporated the plot number and sequential count to create a unique and readily recognizable identification number. Samples were identified in the office setting with additional references and those species names corrected in the data sheets. Data sheets were scanned into PDF format and digitized into MS Excel format. Each plant and associated data was digitized as one record within a plot.

The original plots from 2010 and 2011 were $50 \mathrm{~m}$ (164.0 ft) in length. In 2012, the plant density was sufficient such that an entire $50 \mathrm{~m}$ (164.0 ft) plot could not be surveyed in one day. On June 27, 2012, two plants recorded from a previous survey (a prickly pear cactus and a juniper) were re-located. A portion of the original surveyed area was able to be re-established with spatial precision based on these two plants. This area was re-surveyed in part and may serve as a plot for which direct comparison might be made.

On June 28, 2012 individual $1.0 \mathrm{~m}^{2}\left(10.8 \mathrm{ft}^{2}\right)$ plots were surveyed. The plots were located to be spatially random, accomplished by first identifying a central position in the midst of rainfall simulator measurement and infiltration measurement sites. Using a random number generator, one each of a cardinal direction bearing and distance in meters, limited to $86 \mathrm{~m}(282.2 \mathrm{ft})$, were generated to create a plot location. The cardinal direction was projected from the centroid and plot location was measured in that direction to the distance randomly generated. Constraints on the random plots included being located on or adjacent to the dirt road, or falling on an area that had been excavated from other sampling efforts. In those instances, the next set of random parameters was selected.

To take advantage of additional available field crew, plots were paired at $8.0 \mathrm{~m}(26.2 \mathrm{ft})$ apart. Plots were positioned to be square along the cardinal axes at a north-south and east-west position. Corner points were staked using either metal stakes with washers or rebar. GPS coordinates of the southwest corner were recorded. The same data sheets and same protocol for data collection were employed as from the earlier surveys. 
Data were manually entered from paper data sheets into digital format for analysis. Basic summary statistics were calculated including abundance and diversity as well as summary statistics of plant sizes.

\section{Spatial Statistical Analyses}

Spatial statistics provide a means to assess the relationship between geographic location and a response of interest (e.g., field measurement or calculated metric) and were calculated on data collected for each plot. The data were imported into ArcGIS (Environmental Systems Research Institute, 2011) for these analyses and to visualize both field recorded and calculated response values. Two different spatial statistical calculations were run to address spatial pattern of the biological response data, average nearest neighbor (ANN) and Moran's I, commonly used measures of spatial autocorrelation, i.e., the similarity of data values as a function of their location or proximity to each other.

Average nearest neighbor analysis was performed to determine the likelihood that plant locations within the plots surveyed were the result of random chance and, if not spatially random, to identify if the pattern of the vegetation was clustered or dispersed (systematic). The ANN ratio (Ebdon, 1985) is calculated as:

$$
A N N=\frac{\bar{D}_{O}}{\bar{D}_{E}}
$$

where $\bar{D}_{O}$ is the observed mean distance between each point and its nearest neighbor:

$$
\bar{D}_{O}=\frac{\sum_{i=1}^{n} d_{i}}{n}
$$

and $\bar{D}_{E}$ is the expected mean distance for the data points given a spatially random pattern:

$$
\bar{D}_{E}=\frac{0.5}{\sqrt{n / A}}
$$

Above, $d_{i}$ is the distance between feature $i$ and its nearest neighbor, and $n$ is the total number of features in the study area of size $A$. Euclidean distance was used in calculations.

The null hypothesis in ANN is that the pattern exhibits complete spatial randomness, where the ratio equals a value of one. A z-score, i.e., the difference between one data value and the data mean divided by the data standard deviation, with a corresponding $\mathrm{p}$-value (the probability or confidence that the null hypothesis is correct) determines whether or not to reject the null hypothesis. The z-score is the determinant of whether the pattern is clustered or dispersed and the magnitude of the spatial pattern, if any. An ANN ratio less than 1.0 indicates clustered spatial pattern, whereas a value greater than 1.0 indicates dispersion. 
Moran's I was calculated on individual plant canopy area within plots. This statistic calculates spatial autocorrelation based on both the geographic point location and the point value at that location. The null hypothesis in Moran's I is the attribute analyzed is randomly distributed among the locations sampled. Calculated on plant size, the results indicate spatial correlation of plants that may reflect species grouping and/or underlying controls on plant growth. Scores range from -1.0 (dispersed) to 1.0 (clustered). A z-score and p-value determines the significance level of the Index value. Moran's I (Moran, 1950) is calculated as:

$$
I=\frac{n}{S_{O}} \frac{\sum_{i=1}^{n} \sum_{j=1}^{n} w_{i, j} z_{i} z_{j}}{\sum_{i=1}^{n} z_{i}^{2}}
$$

where $z_{i}$ is the deviation of an attribute for feature $i$ from its mean $\left(x_{i}-\bar{X}\right), w_{i, j}$ is the spatial weight between features $i$ and $j, n=$ the total number of features, and $S_{O}$ is the aggregate of all spatial weights:

$$
S_{O}=\sum_{i=1}^{n} \sum_{j=1}^{n} w_{i, j}
$$

\section{Results for Vegetation Survey, June 2012}

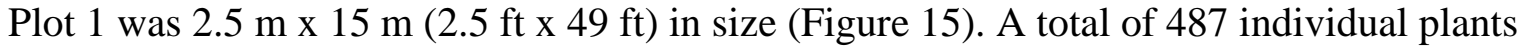
of 17 different species were identified (Table 2, Figure 16). Two plants were not able to be identified and were thought to be a Penstemon and an Arabis (aster). Because they could not be identified with certainty, they were excluded from analysis. A combination of three species and generic perennial grasses comprised almost 85 percent of the plant cover in this plot. Canopy cover by area in this plot was 10 percent. The invasive Bromus tectorum, or cheatgrass, was observed (two occurrences). 


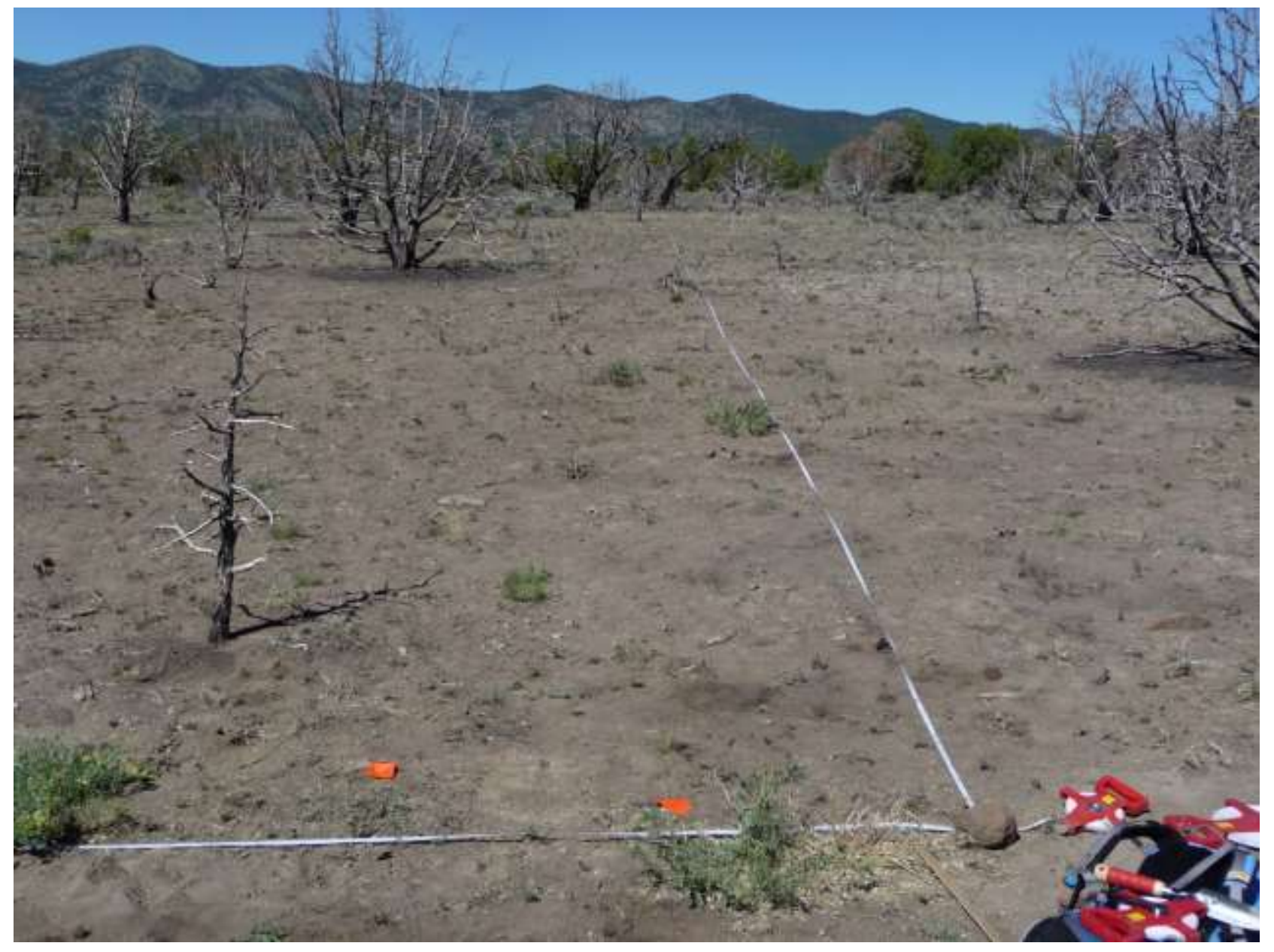

Figure 15. Photograph of Plot 1, surveyed on June 27, 2012. 
Table 2. Results from surveys of Plot 1 on June 27, 2012. Count is the number of plants by species. Duration $=\mathrm{P}$ (perennial) or A (annual). Percent of total is the relative abundance. Mean height is plant height in units $\mathrm{cm}$. Mean area is the mean individual plant canopy area in units $\mathrm{cm}^{2}$. Canopy cover is the percent of the total cover (10 percent) contributed by species.

\begin{tabular}{|c|c|c|c|c|c|c|}
\hline Count & Species & Duration & $\begin{array}{c}\text { Percent of } \\
\text { total } \\
(\%)\end{array}$ & $\begin{array}{l}\text { Mean height } \\
(\mathrm{mm})\end{array}$ & $\begin{array}{l}\text { Mean area } \\
\left(\mathrm{cm}^{2}\right)\end{array}$ & $\begin{array}{c}\text { Canopy } \\
\text { cover } \\
(\%)\end{array}$ \\
\hline 2 & $\begin{array}{l}\text { Acamptopappus } \\
\text { sphaerocephalus }\end{array}$ & $P$ & 0.41 & 3.14 & 5.75 & 0.000 \\
\hline 3 & Agoseris glauca & $\mathrm{P}$ & 0.62 & 144.12 & 3.83 & 0.001 \\
\hline 4 & Astragalus ceramicus & $\mathrm{P}$ & 0.82 & 3.98 & 2.38 & 0.000 \\
\hline 12 & Astragalus lentiginosus & $\mathrm{P}$ & 2.46 & 559.40 & 6.31 & 0.018 \\
\hline 1 & Astragalus purshii & $\mathrm{P}$ & 0.21 & 164.15 & 2.00 & 0.000 \\
\hline 2 & Bromus tectorum & A & 0.41 & 157.47 & 21.00 & 0.001 \\
\hline 2 & Cryptantha humilis & $\mathrm{P}$ & 0.41 & 217.95 & 4.00 & 0.001 \\
\hline 2 & $\begin{array}{l}\text { Eriogonum } \\
\text { caespitosum }\end{array}$ & $\mathrm{P}$ & 0.41 & 94.64 & 3.00 & 0.001 \\
\hline 82 & Eriastrum sparsiflorum & A & 16.84 & 32.17 & 6.38 & 0.007 \\
\hline 81 & Gayophytum diffusum & A & 16.63 & 199.56 & 9.72 & 0.043 \\
\hline 7 & Lesquerella kingii & $\mathrm{P}$ & 1.44 & 47.77 & 2.71 & 0.001 \\
\hline 3 & $\begin{array}{l}\text { Linanthus } \\
\text { campanulatus }\end{array}$ & A & 0.62 & 38.22 & 6.00 & 0.000 \\
\hline 10 & $\begin{array}{l}\text { Pedicularis } \\
\text { centranthera }\end{array}$ & $P$ & 2.05 & 14.08 & 3.35 & 0.000 \\
\hline 102 & perennial grass species & $\mathrm{P}$ & 20.94 & 71.55 & 10.08 & 0.019 \\
\hline 23 & Phlox hoodii & $\mathrm{P}$ & 4.72 & 12.21 & 4.89 & 0.001 \\
\hline 150 & Phlox longifolia & $\mathrm{P}$ & 30.80 & 15.33 & 3.67 & 0.006 \\
\hline 1 & Silene genus & $\mathrm{P}$ & 0.21 & 23.56 & 4.00 & 0.000 \\
\hline 487 & Total & & 100.00 & & & \\
\hline
\end{tabular}




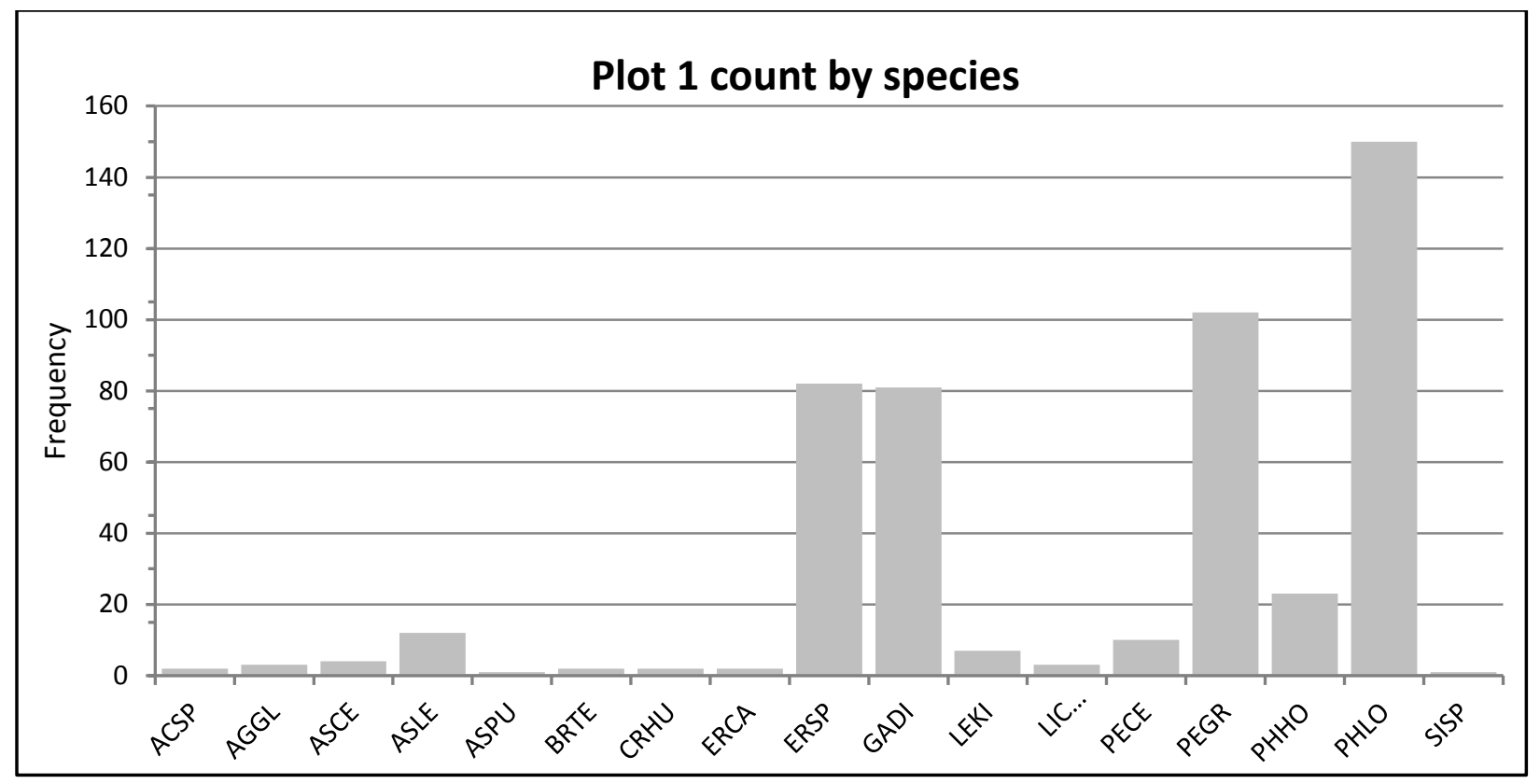

Figure 16. Survey results (abundance and diversity) from Plot 1 show it is dominated by three species and perennial grasses (PEGR).

The most abundant species in Plot 1 was the Longleaf phlox (Phlox longifolia), which is a perennial forb that grows in the spring and summer months. It is fairly well described unlike other of the Great Basin forbs. Unlike other phlox whose form takes clumps or mats, this plant takes a woodier appearance with stems of varying height up to $40 \mathrm{~cm}$ (15.6 in) and typically growing through shrubs. The Longleaf phlox produces profuse white or pinkish flowers, which bloom in late spring, and is propagated by seed or bare roots. It is considered to have medium palatability for browsers and has low palatability for grazers. Considered to have a long life span, it is adapted to medium to coarse textured soils and is highly drought tolerant. The USDA characterizes this plant as having low fire resistance (USDA-NRCS, 2012).

The next most abundant species in this plot was the generic "perennial grasses," which were difficult to key due to heavy grazing. Those perennial grasses that could not be identified were grouped into the general "perennial grass species" category. Perennial grasses accounted for nearly two percent of the canopy cover in Plot 1.

The third most abundant plant was Eriastrum sparsiflorum, the Great Basin woollystar, an annual that grows in small, loose aggregations or as small individual plants; both occurrences were observed. The Great Basin woollystar occurs on dry, gravelly slopes and washes, and has pale blue to lavender colored flowers from May into August. Lastly, Gayophytum diffusum, also called spreading groundsmoke, is an annual in the evening primrose family (Onagraceae). It has tiny white flowers atop thin stems that grow in masses from May through September. It occurs on sandy soils and up to approximately 3,050 m (10,000 ft) throughout the Great Basin.

Individual canopy area is plotted spatially in Figure 17. Results from Average Nearest Neighbor (ANN) spatial analysis showed that the regeneration of plants in Plot 1 was highly clustered $(\mathrm{z}=-8.85, \mathrm{p}<0.000)$. The results are presented graphically in Figure 18. Results from 
Moran's I on plant canopy area with a distance threshold of $10 \mathrm{~m}(32.8 \mathrm{ft})$ also returned a clustered pattern $(I=0.0033, \mathrm{z}=2.46, \mathrm{p}=0.014)$, and plant height was also highly clustered $(I=0.015, \mathrm{z}=6.69, \mathrm{p}<0.000)$.

Plot 2 was $2.5 \mathrm{~m}$ x $2.5 \mathrm{~m}(8.2 \mathrm{ft} \times 8.2 \mathrm{ft})$ in size, although it was originally mapped out to be larger (Figure 19). A total of 294 individual plants of 14 different species were identified (Table 3). Canopy cover by area in this plot was 12 percent. Figure 20 shows these results graphically. The Great Basin woollystar (Eriastrum sparsiflorum) comprised nearly three-quarters of the plant cover in this plot. As a result, although nearly 80 percent of the species observed were perennials, three quarters of the canopy were annual species. The invasive Bromus tectorum, or cheatgrass, was observed (three occurrences).

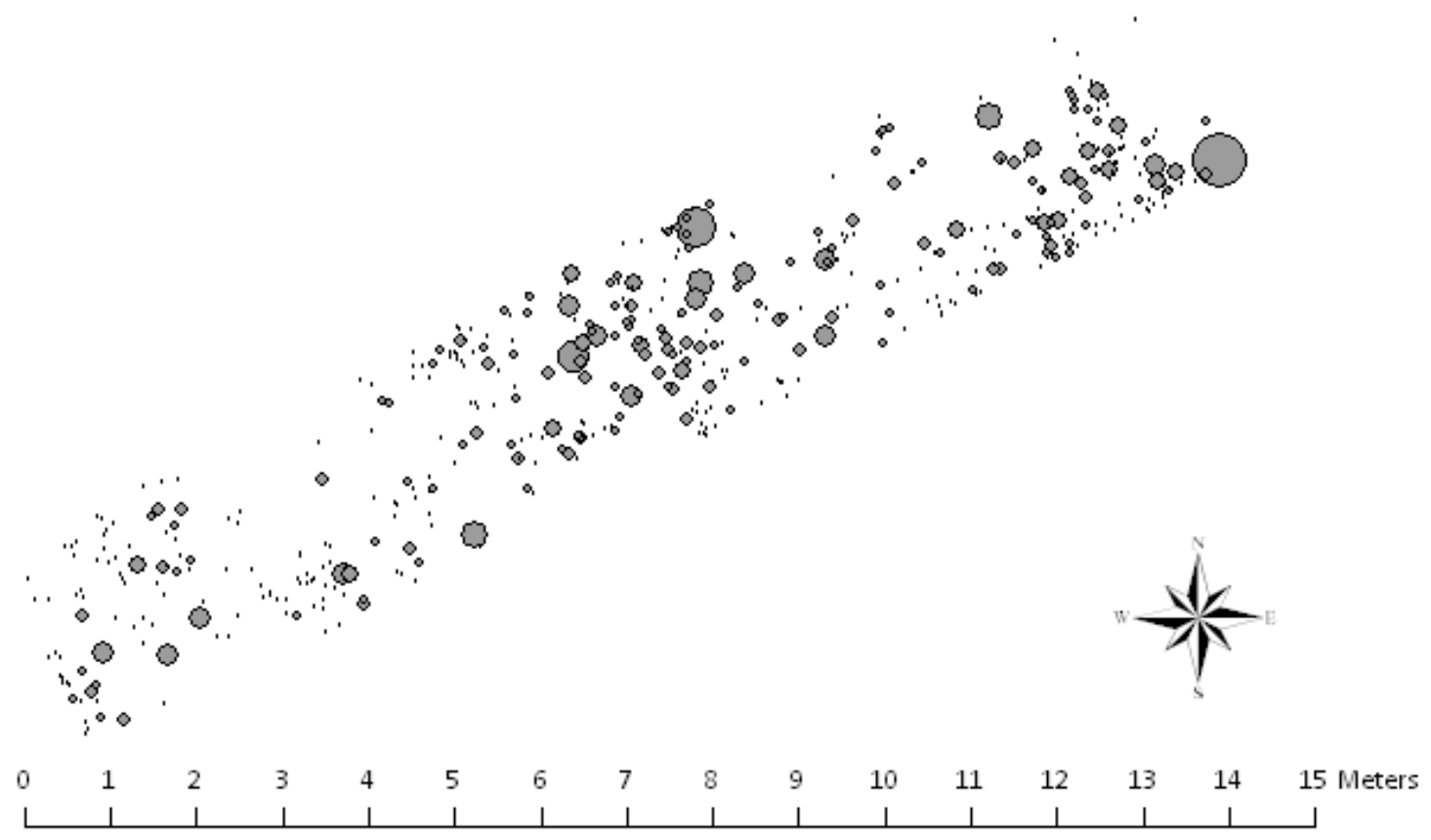

Figure 17. Vegetation data scaled by canopy size $\left(\mathrm{cm}^{2}\right)$ for Plot 1. Larger symbol corresponds to larger plant canopy. 


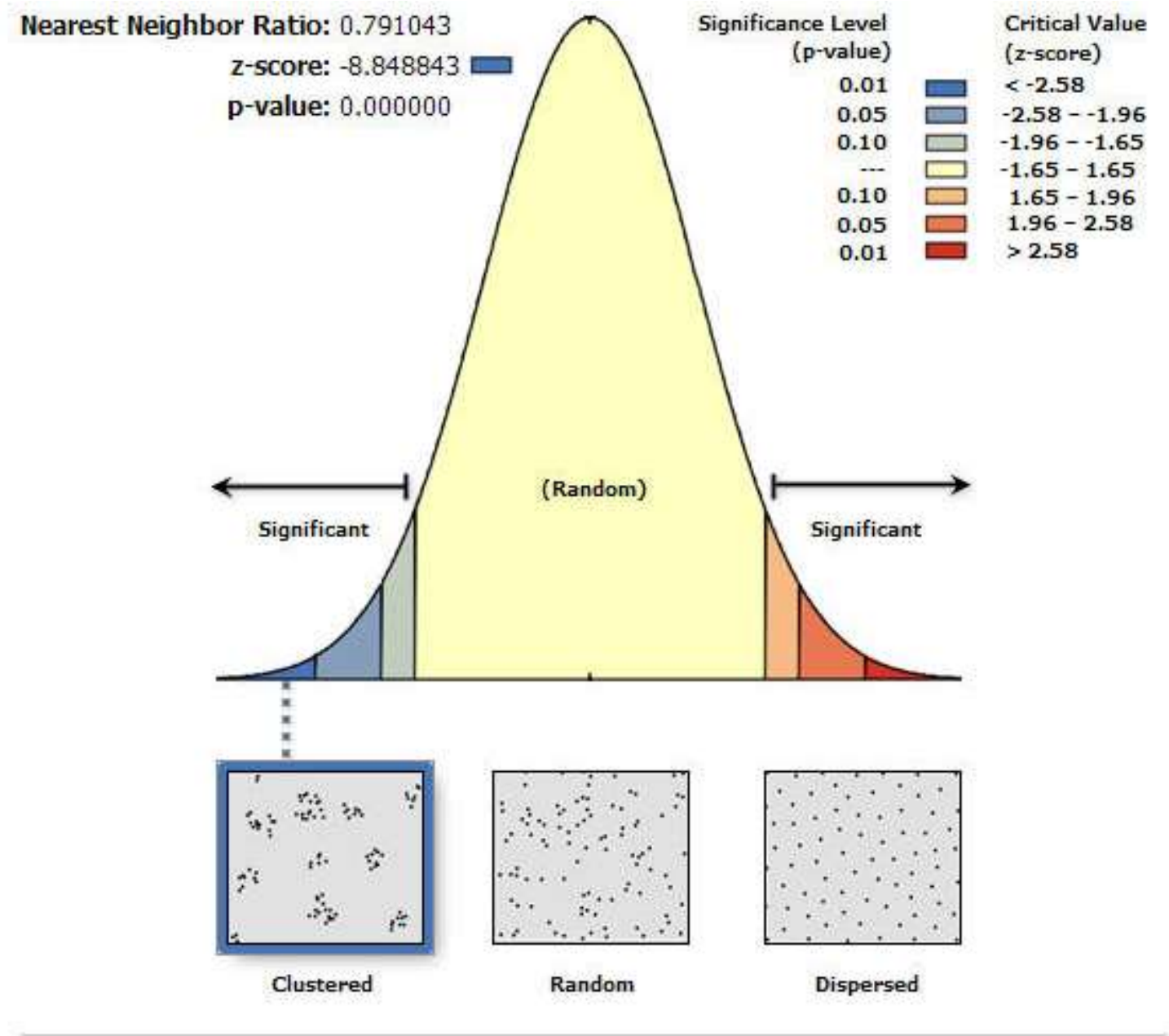

Given the $z$-score of -8.85 , there is a less than $1 \%$ likelihood that this clustered pattern could be the result of random chance.

Figure 18. Results from ANN spatial pattern analysis for Plot 1. 


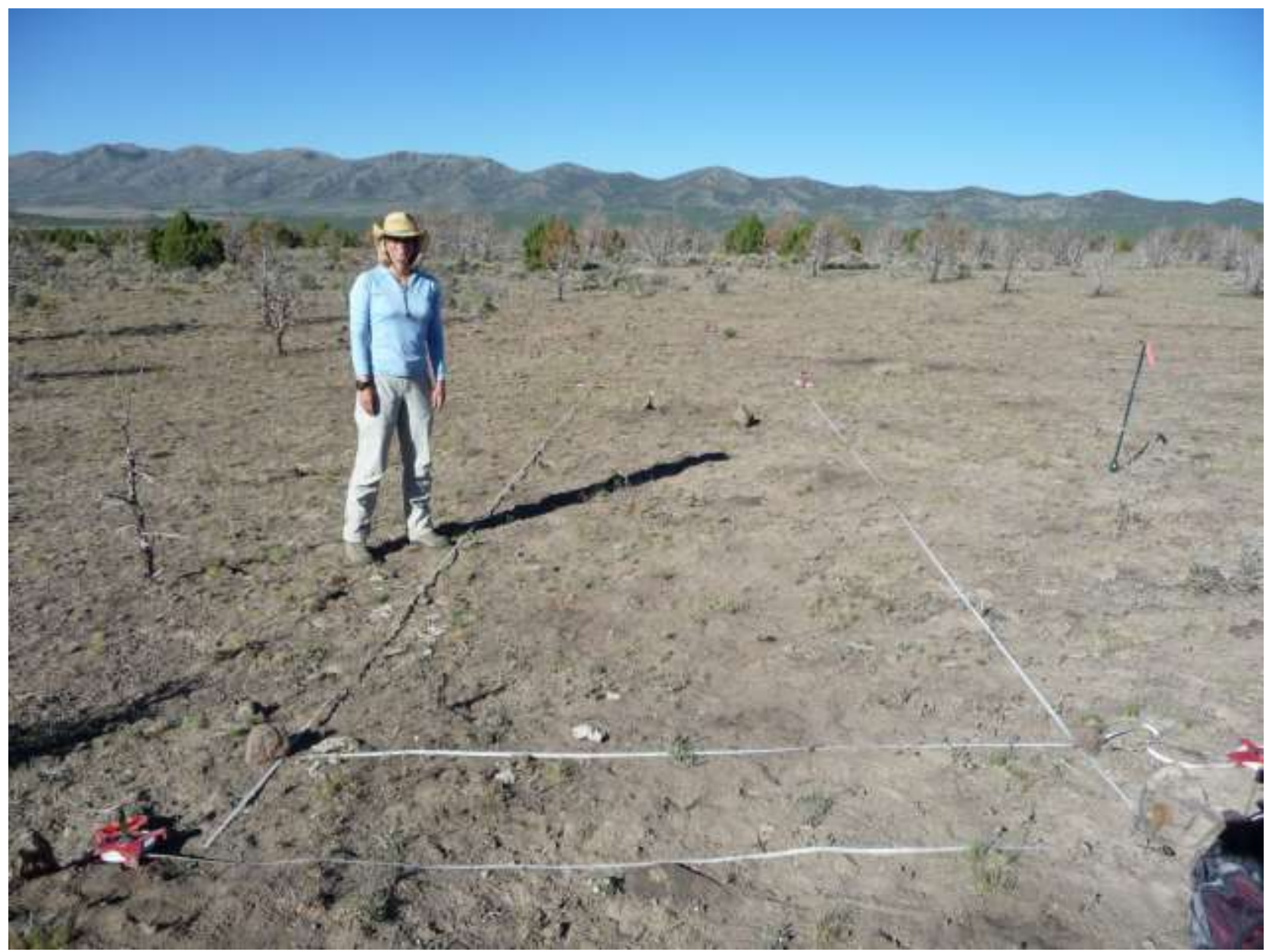

Figure 19. Photograph of Plot 2, surveyed on June 27, 2012. Human shows scale. 


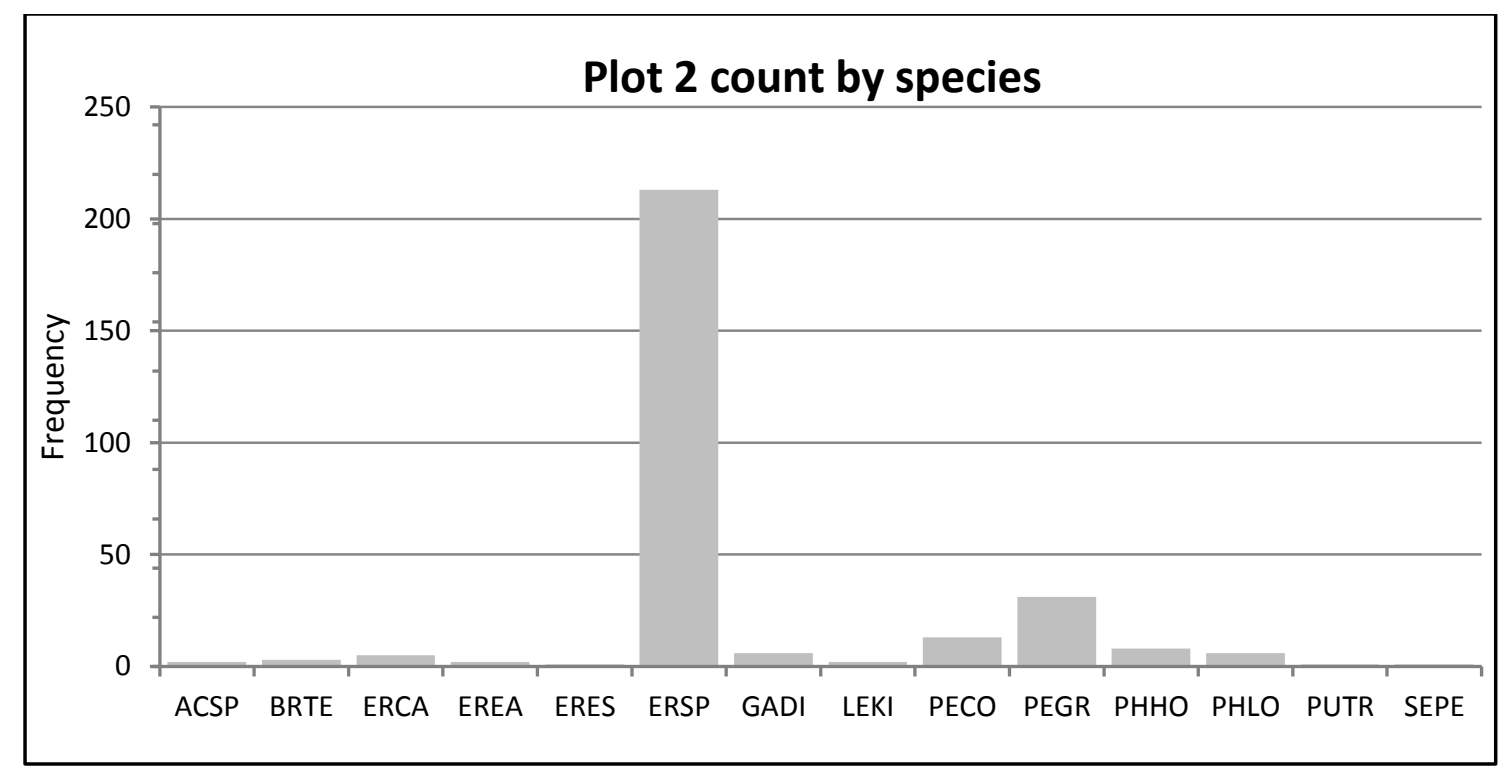

Figure 20. Survey results (abundance and diversity) from Plot 2 show the plot dominated by one species, Eriastrum sparsiflorum (ERSP) known as the Great Basin woollystar.

Table 3. Results from surveys of Plot 2 on June 27, 2012. Count is the number of plants by species. Duration $=\mathrm{P}$ (perennial) or A (annual). Percent of total is the relative abundance. Mean height is plant height in units $\mathrm{cm}$. Mean area is the mean individual plant canopy area in units $\mathrm{cm}^{2}$. Canopy cover is the percent of the total cover (12 percent) contributed by species.

\begin{tabular}{rlcrrrc}
\hline Count & \multicolumn{1}{c}{ Species } & Duration & $\begin{array}{r}\text { Percent of } \\
\text { total } \\
(\%)\end{array}$ & $\begin{array}{c}\text { Mean } \\
\text { height } \\
(\mathrm{cm})\end{array}$ & $\begin{array}{c}\text { Mean area } \\
\left(\mathrm{cm}^{2}\right)\end{array}$ & $\begin{array}{c}\text { Canopy } \\
\text { cover } \\
(\%)\end{array}$ \\
\hline 2 & $\begin{array}{l}\text { Acamptopappus } \\
\text { sphaerocephalus }\end{array}$ & $\mathrm{P}$ & 0.68 & 2.75 & 14.73 & 0.00 \\
3 & Bromus tectorum & $\mathrm{A}$ & 1.02 & 12.67 & 20.29 & 0.00 \\
5 & Eriogonum caespitosum & $\mathrm{P}$ & 1.70 & 1.40 & 96.60 & 0.00 \\
2 & Erigeron eatonii & $\mathrm{P}$ & 0.68 & 2.00 & 40.64 & 0.00 \\
1 & Eriogonum esmeraldense & $\mathrm{P}$ & 0.34 & 3.00 & 3.53 & 0.00 \\
213 & Eriastrum sparsiflorum & $\mathrm{A}$ & 72.45 & 4.58 & 21.64 & 0.03 \\
6 & Gayophytum diffusum & $\mathrm{A}$ & 2.04 & 7.75 & 31.48 & 0.01 \\
2 & Lesquerella kingii & $\mathrm{P}$ & 0.68 & 1.25 & 30.24 & 0.00 \\
13 & Penstemon confusus & $\mathrm{P}$ & 4.42 & 4.15 & 13.97 & 0.00 \\
31 & perennial grass species & $\mathrm{P}$ & 10.54 & 7.03 & 31.02 & 0.07 \\
8 & Phlox hoodii & $\mathrm{P}$ & 2.72 & 2.08 & 22.31 & 0.00 \\
6 & Phlox longifolia & $\mathrm{P}$ & 2.04 & 3.83 & 4.25 & 0.00 \\
1 & Purshia tridentata* & $\mathrm{P}$ & 0.34 & 6.50 & 275.67 & 0.00 \\
1 & Silene genus & $\mathrm{P}$ & 0.34 & 2.50 & 5.50 & 0.00 \\
$\mathbf{2 9 4}$ & Total & & $\mathbf{1 0 0 . 0 0}$ & & & \\
\hline
\end{tabular}

\footnotetext{
*Native shrub.
} 
The most commonly observed plant in Plot 2 was the Great Basin woollystar. Its density contributed approximately three percent of the total canopy cover of this plot. The second most abundant plants were perennial grasses, which also contributed the greatest amount of canopy cover. The Owen's Valley beardtongue (Penstemon confusus) was third most abundant and is a native forb with bright pink to purple flowers. It occurs in Nevada and Utah. One native shrub, bitterbrush (Purshia tridentata) was observed in this plot.

Individual canopy area is plotted spatially in Figure 21. Results from Average Nearest Neighbor (ANN) spatial analysis showed that the regeneration of plants in transect 2 was highly clustered $(\mathrm{z}=-5.49, \mathrm{p}<0.000)$. The results are presented graphically in Figure 22. Results from Moran's I on plant canopy area with a distance threshold of $2.5 \mathrm{~m}(8.2 \mathrm{ft})$ also returned a clustered pattern $(I=-0.0012, \mathrm{z}=2.10, \mathrm{p}=0.036)$ as was plant height distribution $(I=-0.0003, \mathrm{z}=2.24$, $\mathrm{p}=0.025)$.

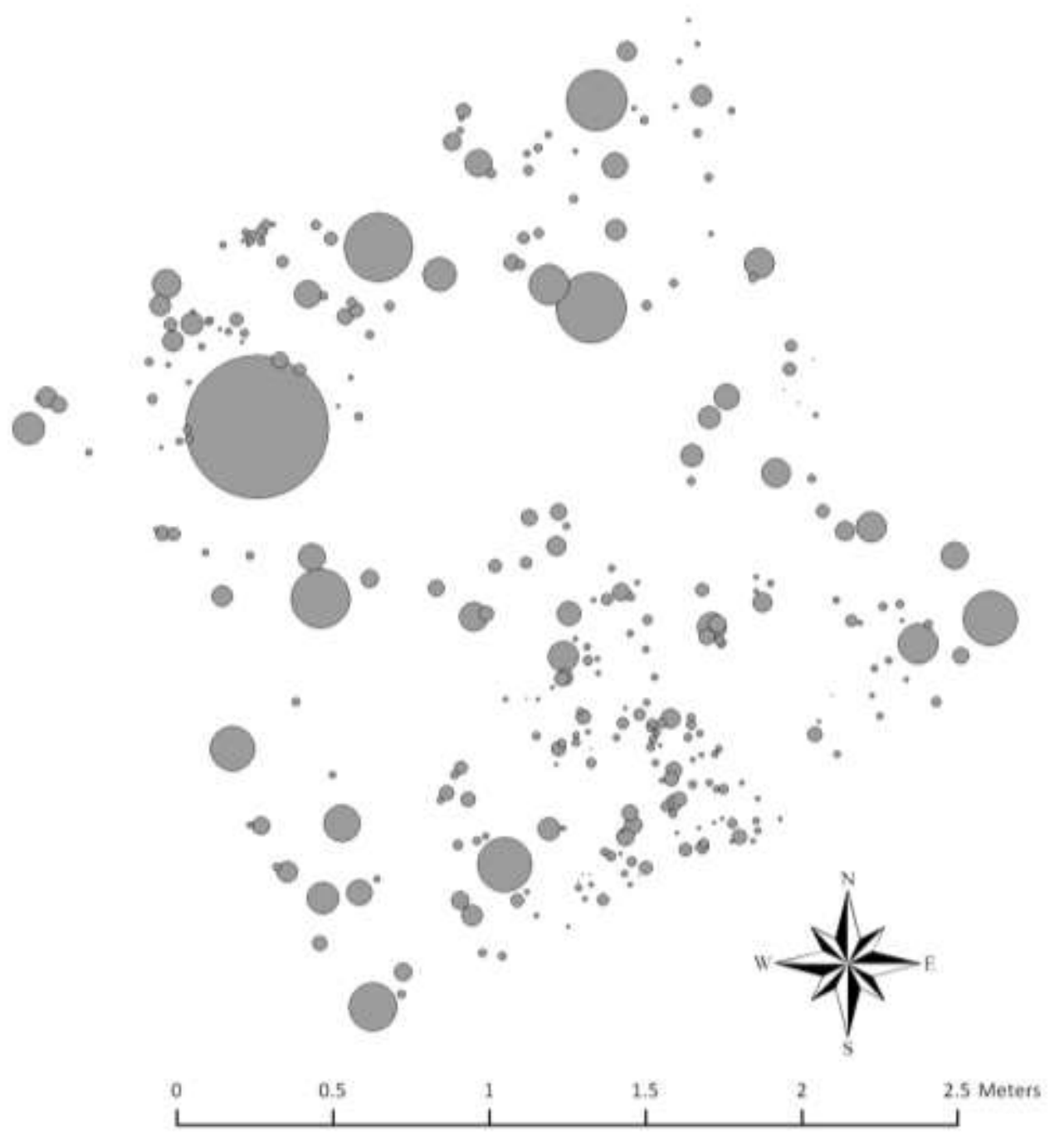

Figure 21. Vegetation data scaled by canopy size $\left(\mathrm{cm}^{2}\right)$ for Plot 2. Larger symbol corresponds to larger plant canopy. 


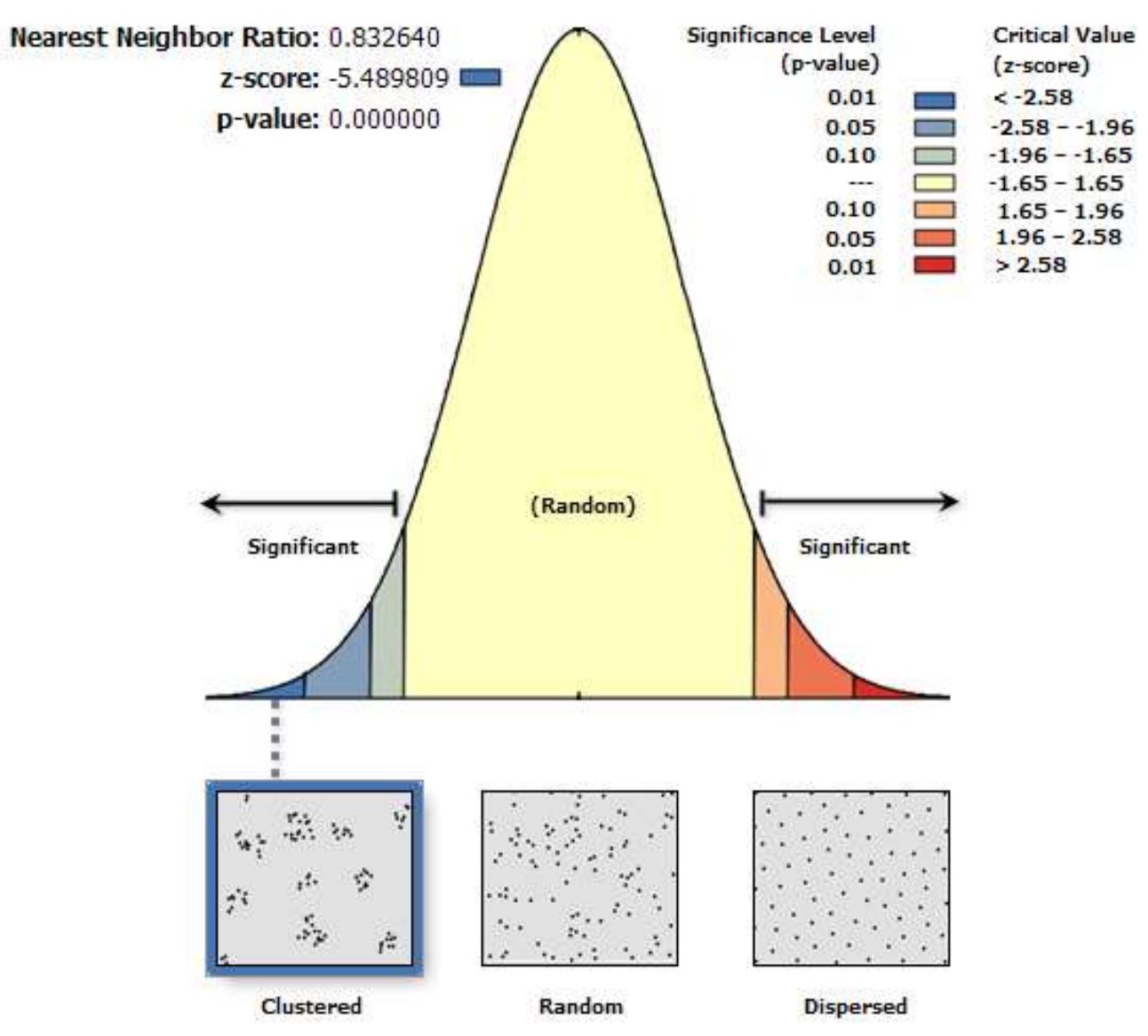

Given the $z$-score of -5.49 , there is a less than $1 \%$ likelihood that this clustered pattern could be the result of random chance.

Figure 22. Results of ANN for Plot 2 shows the spatial pattern of vegetation is highly clustered.

Not all species were present in a clustered pattern. The perennial grasses $(\mathrm{z}=0.273, \mathrm{p}=0.785)$, longleaf phlox $(\mathrm{z}=1.42, \mathrm{p}=0.16)$, and both phlox species grouped $(z=0.344, p=0.731)$ were found to be spatially random within the plot.

For Plot 3, a portion of the original plot area surveyed in a prior year (2010) was located. Therefore the survey of this specific area is possibly useful for comparing to previous survey results, albeit over a very small area. A total of 11 plant species were recorded in the $2.5 \mathrm{~m} \times 1 \mathrm{~m}$ $(8.2 \mathrm{ft} \times 3.28 \mathrm{ft}$ ) plot surveyed in 2012 (Table 4, Figure 23). Total plant abundance was 178 and canopy cover was 10 percent. Eriastrum sparsiflorum (Great Basin woollystar) was the dominant species followed by perennial grasses and Lepidium lasiocarpum (shaggyfruit pepperweed). While approximately two-thirds of the species observed were perennials, annuals accounted for 85 percent of the canopy cover. Although the invasive cheatgrass was not found in this plot, another exotic forb Ranunculus testiculatus (bur buttercup) was found. Considered a weed and native to southeastern Europe, it is toxic if ingested. This exotic forb flowers and produces fruit in the spring. 
Table 4. Results from surveys of Plot 3 on June 27, 2012. Count is the number of plants by species. Duration $=\mathrm{P}$ (perennial) or A (annual). Percent of total is the relative abundance. Mean height is plant height in units $\mathrm{cm}$. Mean area is the mean individual plant canopy area in units $\mathrm{cm}^{2}$. Canopy cover is the percent of the total cover (10 percent) contributed by species.

\begin{tabular}{rlrrrrc}
\hline Count & \multicolumn{1}{c}{ Species } & Duration & $\begin{array}{r}\text { Percent } \\
\text { of total } \\
(\%)\end{array}$ & $\begin{array}{c}\text { Mean height } \\
(\mathrm{cm})\end{array}$ & $\begin{array}{r}\text { Mean } \\
\text { area } \\
\left(\mathrm{cm}^{2}\right)\end{array}$ & $\begin{array}{c}\text { Canopy } \\
\text { cover } \\
(\%)\end{array}$ \\
\hline 4 & Eriogonum caespitosum & $\mathrm{P}$ & 2.25 & 1.75 & 39.12 & 0.006 \\
6 & Erigeron eatonii & $\mathrm{P}$ & 3.37 & 10.00 & 4.12 & 0.001 \\
136 & Eriastrum sparsiflorum & $\mathrm{A}$ & 76.40 & 4.70 & 9.92 & 0.054 \\
1 & Gayophytum diffusum & $\mathrm{A}$ & 0.56 & 11.00 & 32.99 & 0.001 \\
8 & Lepidium lasiocarpum & $\mathrm{A}$ & 4.49 & 6.38 & 23.81 & 0.008 \\
1 & Opuntia polyacantha & $\mathrm{P}$ & 0.56 & 18.00 & 373.85 & 0.015 \\
1 & Penstemon confusus & $\mathrm{P}$ & 0.56 & 3.00 & 87.96 & 0.004 \\
12 & perennial grass species & $\mathrm{P}$ & 6.74 & 12.18 & 20.34 & 0.010 \\
2 & Phlox hoodii & $\mathrm{P}$ & 1.12 & 3.50 & 18.46 & 0.001 \\
1 & Phlox longifolia & $\mathrm{P}$ & 0.56 & 6.00 & 6.28 & 0.000 \\
4 & Ranunculus testiculatus & $\mathrm{A}$ & 2.25 & 1.75 & 39.12 & 0.006 \\
$\mathbf{1 7 8}$ & Total & & $\mathbf{1 0 0 . 0 0}$ & & & \\
\hline
\end{tabular}

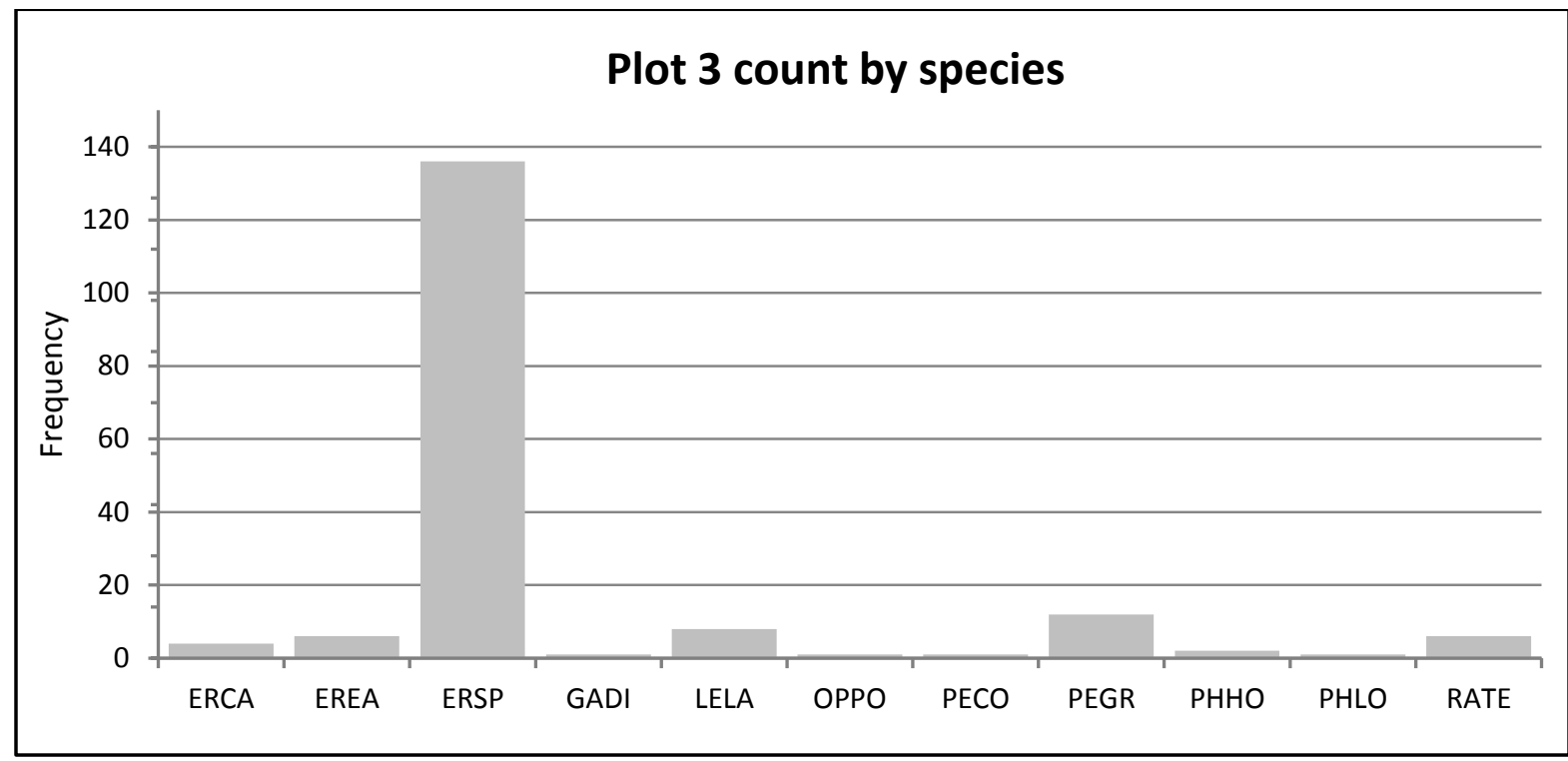

Figure 23. Survey results (abundance and diversity) from Plot 3 show the plot dominated by one species, Eriastrum sparsiflorum (ERSP) known as the Great Basin woollystar. 
Individual canopy area is plotted spatially in Figure 24. Results from Average Nearest Neighbor (ANN) spatial analysis showed that the regeneration of plants in transect 3 was clustered $(\mathrm{z}=-2.14, \mathrm{p}<0.032)$. The results are presented graphically in Figure 25. Results from Moran's I on plant canopy area with a distance threshold of $2.5 \mathrm{~m}(8.2 \mathrm{ft})$ also returned a highly clustered pattern $(I=-0.0008, \mathrm{z}=4.99, \mathrm{p}<0.000)$ although plant height distribution was random $(\mathrm{I}=\mathrm{-}$ $0.0052, \mathrm{z}=0.47, \mathrm{p}=0.641)$.

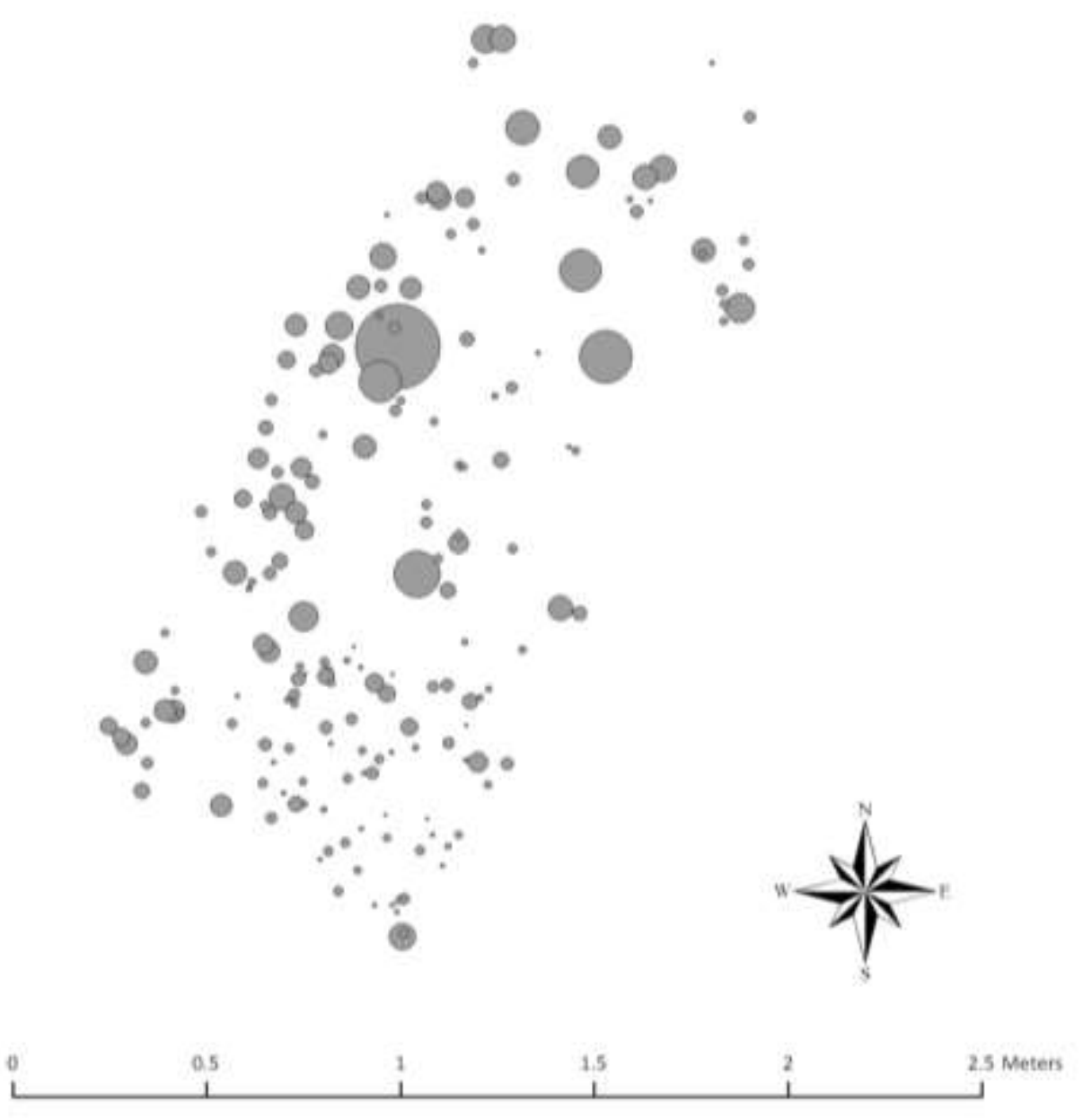

Figure 24. Vegetation data scaled by canopy size $\left(\mathrm{cm}^{2}\right)$ for Plot 3. Larger symbol corresponds to larger plant canopy. 


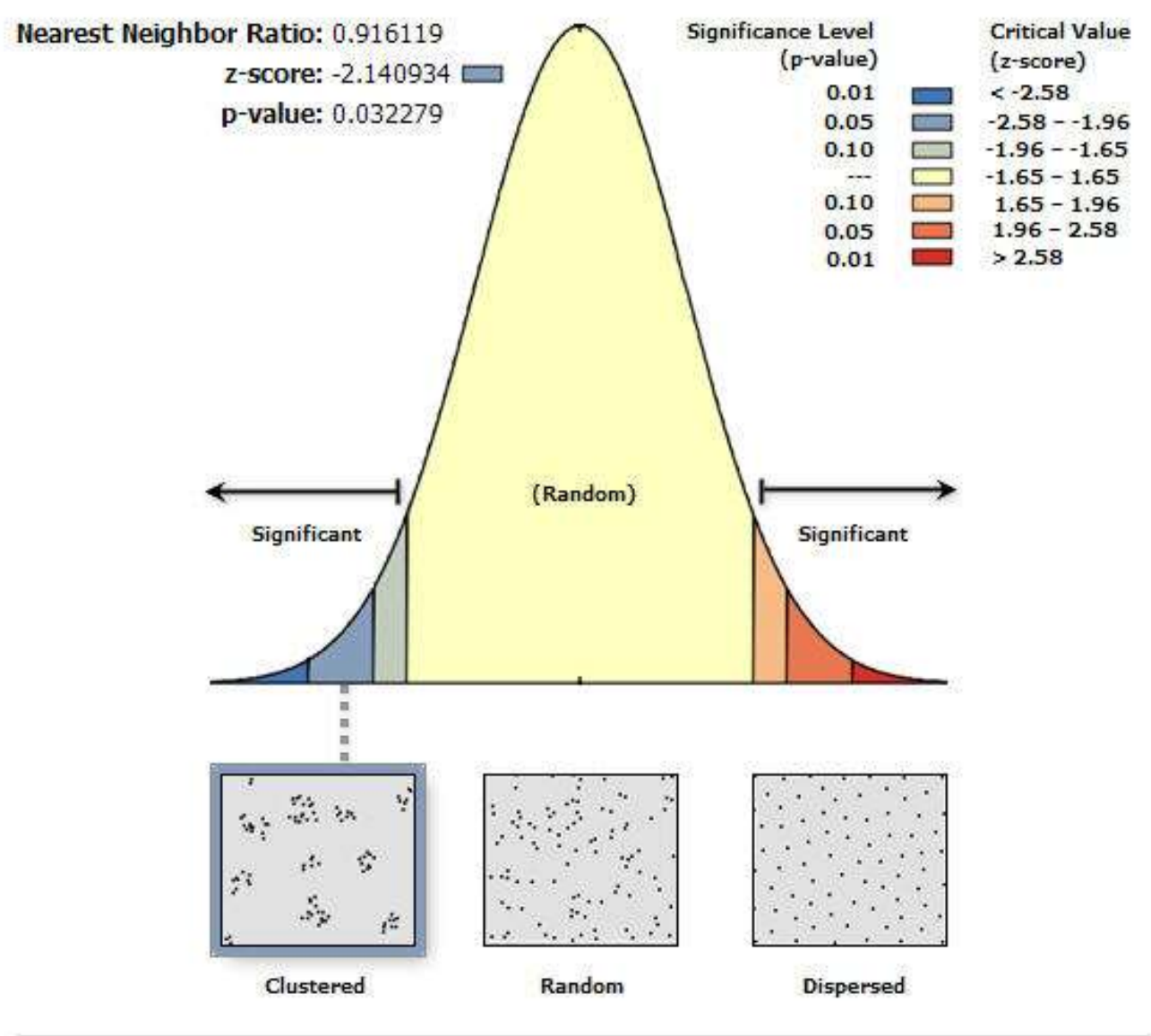

Given the $z$-score of -2.14 , there is a less than $5 \%$ likelihood that this clustered pattern could be the result of random chance.

Figure 25. Results of ANN for Plot 3 shows the spatial pattern of vegetation is clustered.

Survey results for the same geographic area covered in Plot 3 for 2011 and 2012 are presented in Figure 26. The earlier survey included a wider swath. In 2011, very few plants were recorded compared with 2012.

\section{Spatially Random Small Plots}

Eight paired small plots $\left(1.0 \mathrm{~m}^{2}, 10.8 \mathrm{ft}^{2}\right)$ were surveyed for a total of 16 plots (Figure 27). A total of 24 plant species were identified across the plots (Table 5 and Figure 28) including grass, forb/herb, and shrub species. Mean canopy cover across all plots was nine percent and ranged from one percent to 15 percent within a plot. Species frequency histograms for all plots are shown in Figure 29. Perennial grasses, spiny phlox, and shaggyfruit pepperweed combined contribute nearly half of the canopy cover ( 46 percent) in the plots surveyed. 


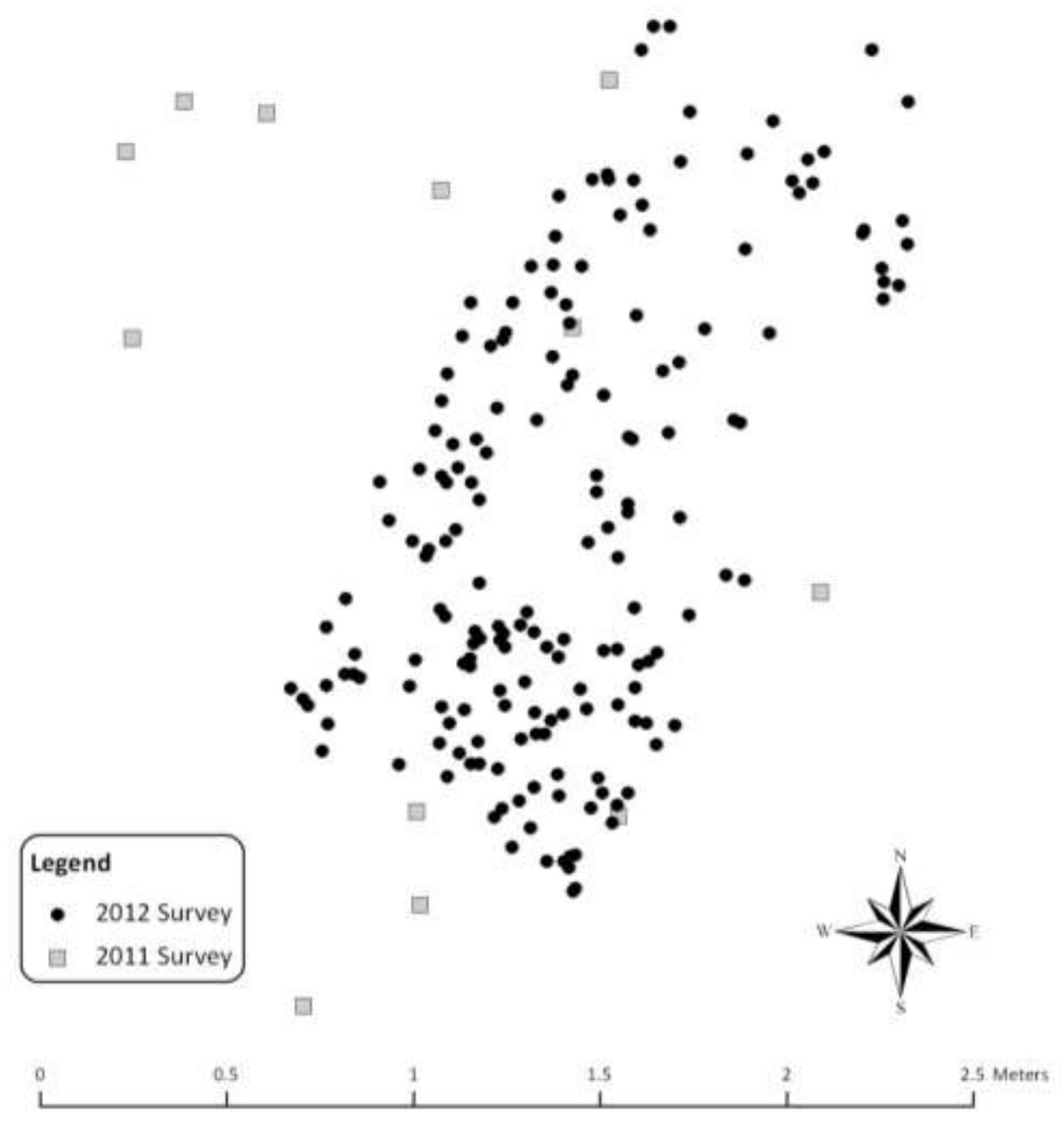

Figure 26. Results from 2011 and 2012 vegetation surveys overlaid in space for comparison. 


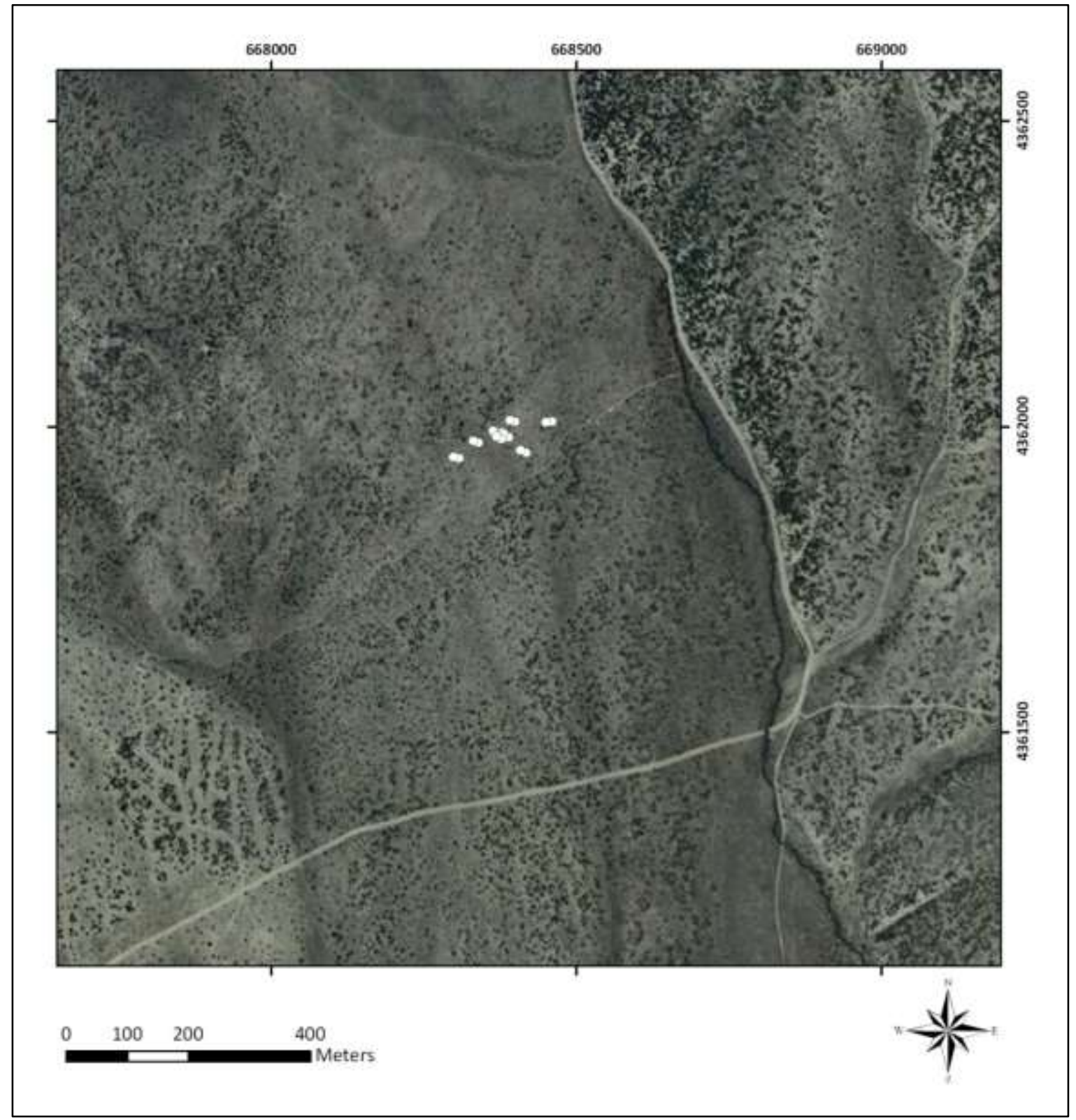

Figure 27. Location of random small plots surveyed on June 27, 2012. 


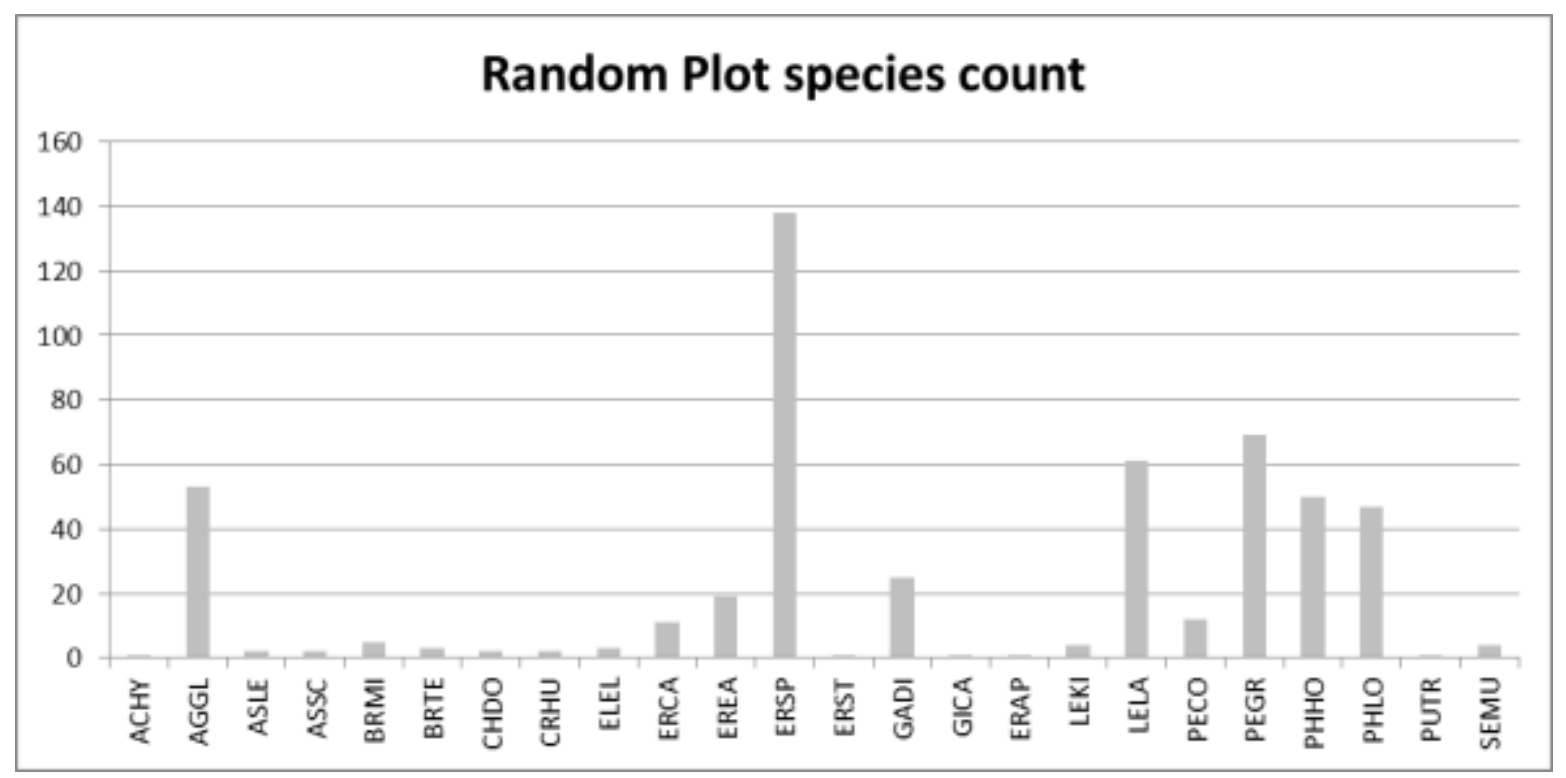

Figure 28. Survey results (abundance and diversity) across all random small plots.

Table 5. Abundance and diversity combined across all random small plots.

\begin{tabular}{rlrrrc}
\hline Count & \multicolumn{1}{c}{$\begin{array}{c}\text { Species } \\
\text { Achnatherum hymenoides }\end{array}$} & $\begin{array}{c}\text { Percent } \\
\text { of total } \\
(\%)\end{array}$ & $\begin{array}{r}\text { Mean } \\
\text { area } \\
\left(\mathrm{cm}^{2}\right)\end{array}$ & $\begin{array}{r}\text { Mean height } \\
(\mathrm{cm})\end{array}$ & $\begin{array}{c}\text { Canopy } \\
\text { cover } \\
(\%)\end{array}$ \\
\hline 1 & 0.00 & 464.96 & 11.50 & 0.03 \\
2 & Agoseris glauca & 0.10 & 9.98 & 2.99 & 0.04 \\
2 & Astragalus lentiginosus & 0.00 & 20.03 & 1.25 & 0.00 \\
5 & Aster scopulorum & 0.00 & 36.72 & 3.50 & 0.01 \\
3 & Brickellia microphylla & 0.01 & 29.14 & 3.00 & 0.01 \\
2 & Chaenactis douglasii & 0.01 & 14.40 & 11.00 & 0.00 \\
2 & Cryptantha humilis & 0.00 & 108.78 & 5.50 & 0.02 \\
3 & Elymus elymoides & 0.00 & 128.81 & 2.00 & 0.02 \\
1 & Erigeron aphanactis & 0.01 & 48.56 & 12.33 & 0.01 \\
11 & Eriogonum caespitosum & 0.00 & 56.55 & 4.00 & 0.00 \\
19 & Erigeron eatonii & 0.02 & 8.75 & 2.09 & 0.01 \\
138 & Eriastrum sparsiflorum & 0.04 & 8.75 & 2.09 & 0.04 \\
1 & Eriogonum strictum & 0.27 & 7.22 & 4.27 & 0.07 \\
25 & Gayophytum diffusum & 0.00 & 14.14 & 16.00 & 0.00 \\
1 & Gilia cana & 0.05 & 11.95 & 7.98 & 0.20 \\
1 & Erigeron aphanactis & 0.00 & 9.42 & 7.00 & 0.00 \\
4 & Lesquerella kingii & 0.00 & 56.55 & 4.00 & 0.00 \\
61 & Lepidium lasiocarpum & 0.01 & 93.27 & 2.25 & 0.03 \\
12 & Penstemon confusus & 0.12 & 29.00 & 9.00 & 0.12 \\
69 & perennial grass species & 0.02 & 12.32 & 2.96 & 0.01 \\
50 & Phlox hoodii & 0.13 & 45.52 & 8.38 & 0.22 \\
47 & Phlox longifolia & 0.10 & 34.45 & 3.19 & 0.12 \\
1 & Purshia tridentata & 0.09 & 10.24 & 3.29 & 0.03 \\
4 & Senecio multilobatus & 0.00 & 37.70 & 5.00 & 0.00 \\
\hline & & 0.01 & 11.78 & 2.00 & 0.00 \\
\hline
\end{tabular}


The dominance of Eriastrum sparsiflorum is from a relatively high abundance in two plots, which together contributed nearly 85 percent of its occurrence. Similarly the annual Lepidium lasiocarpum (shaggyfruit pepperweed) was identified in only three plots yet resulted in the third highest abundant plant species. The perennial herb A. glauca (pale agoseris) occurred in only two plots yet was the fourth most abundant plant across the plots. Perennial grasses on the other hand were found to occur in 14 of the 16 plots and had a relatively even distribution among those plots. Nearly half of the spiny phlox (Phlox hoodii) was recorded in one plot and the longleaf phlox was identified in eight different plots with a more even frequency distribution. More data are needed.

Table 6 shows the species richness and spatial distribution of plants recorded from the random plots. Plant distribution was primarily random and in a few instances dispersed. In one instance, the pattern was clustered. The spatial pattern of species richness (Figure 30) across the plots was random $(\mathrm{I}=-0.053, \mathrm{z}=0.13, \mathrm{p}=0.90)$, however this metric is ideally calculated on a minimum of 30 data points, twice as many as were available. This metric would indicate if there are relationships with other landscape attributes that are not seen at the scale measured. The results from the randomized sample plot data present a different spatial pattern than that found in the larger survey areas, indicating a potential measurement scale dependency.

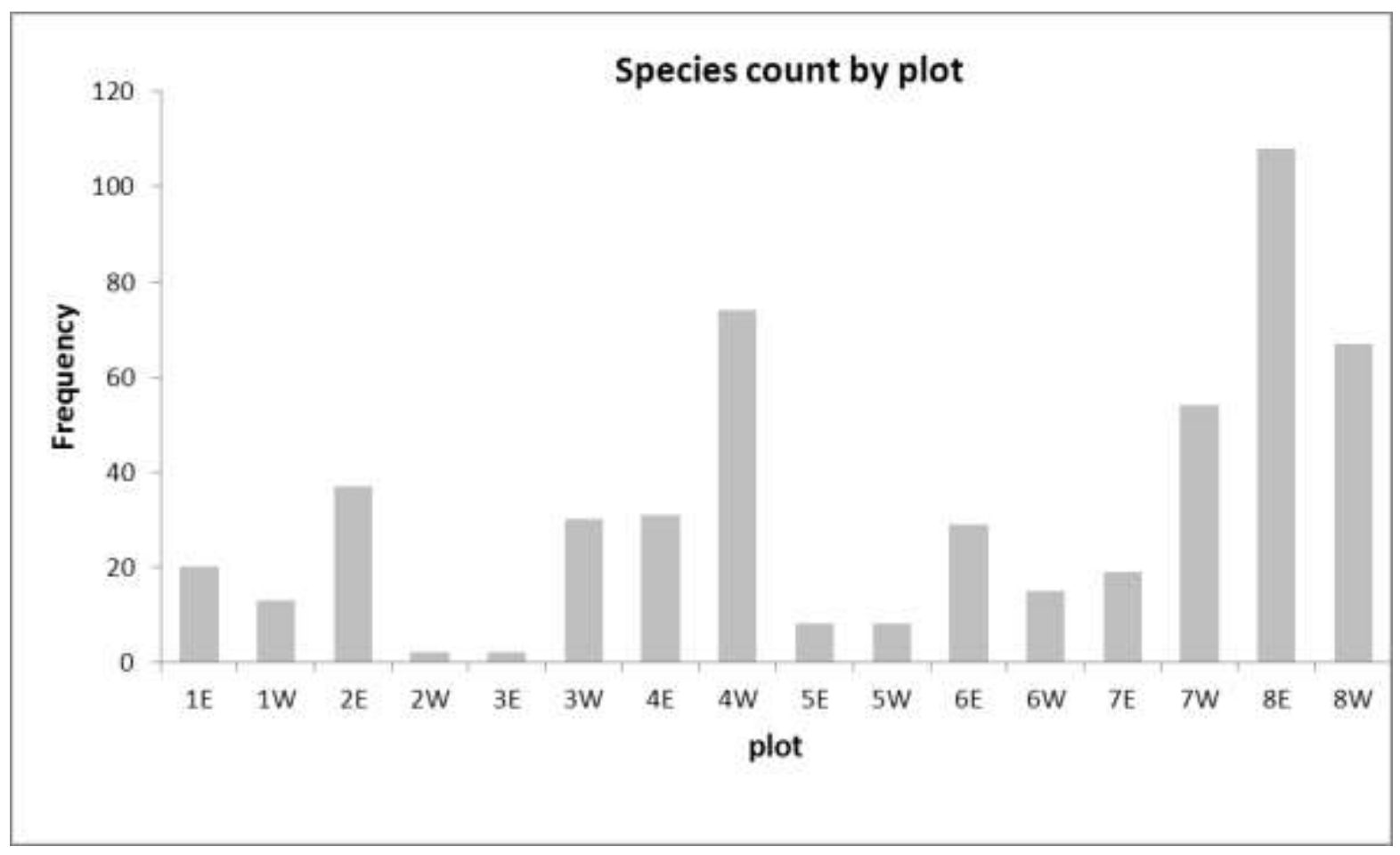

Figure 29. Diversity of species recorded in each of 16 random small plots. 
Table 6. Species count and canopy cover by plot. Richness is the number of species recorded in the plot. Pattern = random " $R$," clustered " $C$," dispersed " $D$," insufficient plant count "N/A" (ANN z-score and p-value) from ANN analysis.

\begin{tabular}{lrrrl}
\hline Plot & $\mathrm{n}$ & $\begin{array}{c}\text { Canopy Cover } \\
(\%)\end{array}$ & Richness & \multicolumn{1}{c}{ Pattern } \\
\hline $1 \mathrm{E}$ & 20 & 0.10 & 6 & $\mathrm{R}(\mathrm{z}=-0.07, \mathrm{p}=0.94)$ \\
$1 \mathrm{~W}$ & 13 & 0.08 & 5 & $\mathrm{D}(\mathrm{z}=2.22, \mathrm{p}=0.03)$ \\
$2 \mathrm{E}$ & 37 & 0.10 & 10 & $\mathrm{R}(\mathrm{z}=1.206, \mathrm{p}=0.23)$ \\
$2 \mathrm{~W}$ & 2 & 0.03 & 2 & $\mathrm{~N} / \mathrm{A}$ \\
$3 \mathrm{E}$ & 2 & 0.09 & 2 & $\mathrm{~N} / \mathrm{A}$ \\
$3 \mathrm{~W}$ & 30 & 0.12 & 7 & $\mathrm{R}(\mathrm{z}=0.87, \mathrm{p}=0.39)$ \\
$4 \mathrm{E}$ & 31 & 0.06 & 4 & $\mathrm{R}(\mathrm{z}=1.6, \mathrm{p}=0.10)$ \\
$4 \mathrm{~W}$ & 74 & 0.11 & 6 & $\mathrm{R}(\mathrm{z}=0.81, \mathrm{p}=0.42)$ \\
$5 \mathrm{E}$ & 8 & 0.01 & 2 & $\mathrm{D}(\mathrm{z}=4.51, \mathrm{p}<0.00)$ \\
$5 \mathrm{~W}$ & 8 & 0.02 & 2 & $\mathrm{R}(\mathrm{z}=0.68, \mathrm{p}=0.50)$ \\
$6 \mathrm{E}$ & 29 & 0.10 & 7 & $\mathrm{D}(\mathrm{z}=3.44, \mathrm{p}<0.001)$ \\
$6 \mathrm{~W}$ & 15 & 0.10 & 5 & $\mathrm{C}(\mathrm{z}=-7.41, \mathrm{p}=0.00)$ \\
$7 \mathrm{E}$ & 19 & 0.12 & 8 & $\mathrm{D}(\mathrm{z}=2.86, \mathrm{p}=0.004)$ \\
$7 \mathrm{~W}$ & 54 & 0.15 & 7 & $\mathrm{R}(\mathrm{z}=0.86, \mathrm{p}=0.39)$ \\
$8 \mathrm{E}$ & 108 & 0.11 & 10 & $\mathrm{R}(\mathrm{z}=0.60, \mathrm{p}=0.55)$ \\
$8 \mathrm{~W}$ & 67 & 0.11 & 5 & $\mathrm{R}(\mathrm{z}=1.36, \mathrm{p}=0.17)$ \\
\hline
\end{tabular}

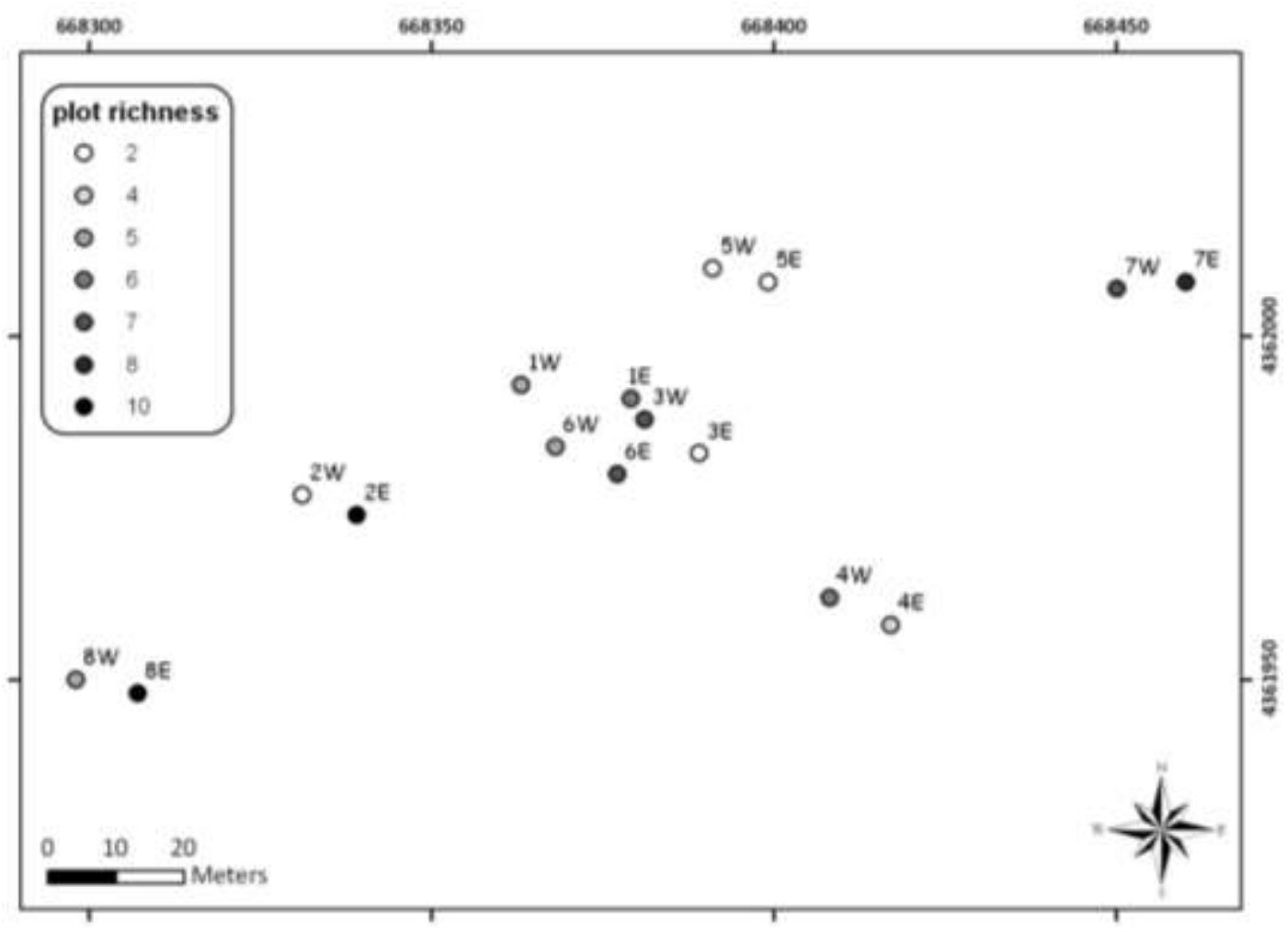

Figure 30. Species richness for each of the paired random small plots surveyed. 


\section{Other Observations}

The difference in species distribution observed between the three previously surveyed plot areas and the randomized plots showcases the microscale variability of conditions, which in turn is reflected in the vegetation species and abundances.

During the survey, cows were observed in the area surveyed. Evidence of cow activity included heavily grazed vegetation, especially of native grasses, manure, and footprints. Additionally, other plant species were observed, which were not identified within the plots surveyed. An expanded survey effort would contribute towards a more complete inventory. Invasive plant species were also observed with increasing density towards the dirt roads.

\section{SUMMARY}

The purpose of this report is to present data and findings regarding the monitoring of soil erosion by wind and water, as well as to document vegetation response following a fire at a site comparable to areas on the northern portion of the NNSS and on the TTR. The site, near Ely, Nevada, and referred to as the Gleason Fire site, was chosen not only for its similarity to areas of interest, but because it was a prescribed fire that allowed measurements immediately before and after the fire (within days of the fire), as well as monitoring of windblown particulate material, soil, and runoff and sediment over a 34-month post-fire period. Sampling and analysis included measuring relevant characteristics on burned understory soils and burned interspace soils, and comparing those data with data obtained from the same measurements on unburned soils.

Wind erosion data were collected with a wind tunnel analog instrument (PI-SWERL) that measured $\mathrm{PM}_{10}$ at different wind speeds. Emissions captured on exhaust filters on the PI-SWERL allowed for the determination of the chemical composition of the material. The condition of the soil was determined via analysis of measured soil hydraulic properties. Water erosion data were generated by use of a rainfall simulator and measurement of collected runoff and suspended sediment. Laboratory analysis of the sediment provided data regarding the amount and size of particles present in the runoff. Vegetation regeneration was documented in the burned area.

The texture and structure of the soils at the burn site were characterized immediately before and after the fire. The structural change was striking in that a well-structured, cohesive soil became a structureless, non-cohesive mass after the fire. The bulk density and porosity data indicated the post-fire soil was less dense than unburned soil. Soil surface cohesion differences persisted to the end of the study at 34 months after the fire.

Wind erosion from soils exposed to fire was elevated compared to unburned soils and did not return to pre-fire level during the duration of the project. Analysis of the $\mathrm{PM}_{10}$ data indicated that the amount of emissions from burned understory soils was greater than from burned interspace soils. Thus, soils beneath burned vegetation (understory soils) were the major source area for wind-borne particulate material.

Ash and hydrophobicity (water repellency) were evident on post-burn understory soils up to 12 months after the fire. The frequency of runoff on burned interspace soils was greater than on unburned soils throughout the duration of the project. The median size of sediment from interspace soils, both burned and unburned, was about half the size of sediment suspended in runoff from 
burned understory soils, indicating that burned understory soils were likely not source areas for sediment, and thus runoff. Both wind and water erosion data showed differences between burned interspace and understory sites. Therefore, even though the fire burned nearly all the vegetation at the site, leaving only burned plant bases and slight topographic soil mounds, the effect of the vegetation on soil properties persisted after the fire. A post-fire vegetation survey showed the return of many native species to the site. The presence of invasive Bromus tectorum (cheatgrass) by the end of the study period was noted.

In conclusion, the data show that elevated levels of soil erosion by wind and water erosion from a burned site were evident for at least 34 months (nearly three years) after a fire for this soil, precipitation, vegetation, and land management system. The fire effect on soil erosion may be a change in soil structure during the fire (from a strong definable pre-burn structure to a weakly cohesive, massive structureless soil), which leaves material and soil particles more susceptible to transport by wind and water. Although some surface development was observed in burned interspace areas, it was significantly less than on unburned areas. The size of sediment suspended in runoff is comparable to that in wind-borne emissions, even though the source area is differentunderstory soils for wind and interspace soils for water. Based on the measurements made at the Gleason site after the fire, it is unclear whether the greater erosion potential would be expected to be primarily from wind, as more of the landscape surface (i.e., burned understory soils) will be exposed to wind until the vegetation becomes re-established and matures, or water, as precipitation will more frequently result in runoff. However, due to the persistence of vegetation on soil properties even after a fire, an areal post-fire response of wind and water erosion may be possible based on knowledge of the pre-fire spatial distribution of vegetation.

\section{REFERENCES}

Albalasmeh, A.A., M. Berli, D.S. Shafer, and T.A. Ghezzehei, 2013. Degradation of moist soil aggregates by rapid temperature rise under low intensity fire. Plant and Soil, 362:335-344.

ASTM, 2000. Standard C1070-01: Test method for determining particle size distribution of alumina or quartz by laser light scattering. ASTM International, West Conshohoken, PA.

Beatley, J.C., 1976. Vascular plants of the Nevada Test Site and central-southern Nevada. National Technical Information Service, TID-26881, Springfield, VA, p. 308.

Berli, M., L. Chen, and M. Young, 2008. Wildfire effects on watershed hydrologic processes: An introduction for hydraulic engineers, watershed managers and planners. Desert Research Institute, Nevada System of Higher Education. Publication No. 41243, p. 42.

Caldwell, T.G., M.H. Young, J. Zhu, and E.V. McDonald, 2008. Spatial structure of hydraulic properties from canopy to interspace in the Mojave Desert. Geophysical Research Letters, 35, L19406, doi:10.1029/2008GL035095.

Clark County (Nevada) Regional Flood Control District, 1999. Hydrologic Criteria and Drainage Design Manual, Las Vegas, NV.

Chief, K., T.P.A. Ferré, and B. Nijssen, 2006. Field testing of a soil corer air permeameter (SCAP) in desert soils. Vadose Zone Journal, 5:1257 - 1263. 
Chief, K., M.H. Young, and D.S. Shafer, 2012. Low intensity, fire-induced changes of soil structure and hydraulic properties in a woodland-rangeland ecosystem. Soil Science Society of America Journal, 76:1965-1977.

DeBano, L.F., 2000. Water repellency in soils: A historical overview. Journal of Hydrology, 231:4-32.

Doerr, S.H., 1998. On standardizing the 'water drop penetration time' and the 'molarity of an ethanol droplet' techniques to classify soil hydrophobicity: A case study using medium textured soils. Earth Surface Processes and Landforms, 23:663-668.

DUST-QUANT, 2008. User's Guide for the Miniature Portable In-Situ Wind ERosion Lab (PISWERL), Version 1.2, July 25, 2008. DUST-QUANT LLC, Las Vegas, NV.

Ebdon, D., 1985. Statistics in Geography. Basil Blackwell, Inc., Cambridge, MA.

Environmental Systems Research Institute, 2011. ArcGIS Desktop: Release 10. Redlands, CA.

Etyemezian, V., I. Kavouras, D. DuBois, D. Shafer, K. Chief, J. Miller, and G. Nikolich, 2011. Emissions of soil particulate matter during a controlled burn: DRAFT report on preliminary measurements completed near Ely, Nevada.

Etyemezian, V., G. Nikolich, S. Ahonen, M. Pitchford, M. Sweeny, R. Purcell, J. Gilles, and H. Kuhns, 2007. The Portable In Situ Wind Erosion Laboratory (PI-SWERL): A new method to measure $\mathrm{PM}_{10}$ windblown dust properties and potential for emissions. Atmospheric Environment, 41:3789-3796.

Gee, G.W., and D. Or, 2002. Particle-size analysis. In J.H. Dane and G. C. Topp, (ed.), Methods of Soil Analysis, Part 4, Physical Methods. Soil Science Society of America Inc., Madison, Wisconsin. pp. 255-293.

Hansen, D.J. and W.K. Ostler, 2004. A survey of vegetation and wildland fire hazards on the Nevada Test Site. Bechtel Nevada Ecological Services, DOE/NV/11718-981, p. 57.

Jalbert, M. and J.H. Dane, 2003. A handheld device for intrusive and nonintrusive field measurements of air permeability. Vadose Zone Journal, 2:611-617.

Julien, P.Y., 1998. Erosion and Sedimentation. Cambridge University Press, NY.

Malm, W.C., J.F. Sisler, D. Huffman, R.A. Eldred, and T.A. Cahill, 1994. Spatial and seasonal trends in particle concentration and optical extinction in the United States. Journal of Geophysical Research, 99(D1):1347-1370.

Miller, J.J and R.H. French, 2001. Watershed responses in arid environments. American Society of Civil Engineers, Environmental and Water Resources Institute, Conference Proceedings, Annual Conference, 2001, Orlando, Florida.

Munn, J.R. and G.L. Huntington, 1976. A portable rainfall simulator for erodibility And infiltration measurements in rugged terrain. Soil Science Society of America Journal, 40:622-624.

Mutchler, C.K. and W.C. Moldenhauer, 1963. Applicator for laboratory rainfall simulator. Transactions of American Society of Agricultural Engineers, 6:220-222. 
Moran, P.A.P., 1950. Notes on continuous stochastic phenomena. Biometrika, 37(1/2):17-23.

National Climatic Data Center, 2000. Climatography of the United States No. 20 1971-2000, Online. Available at http://www.drought.unl.edu/whatis/climographs/pdf/Ely.pdf (December 29, 2010).

National Oceanic and Atmospheric Administration-National Weather Service, 2004. Online. Available at http://www.hdsc.nws.noaa.gov. (2004).

Neary, D.G., K.C. Ryan, L.F. DeBano, 2008. Wildland fire in ecosystems: effects of fire on soils and water. General Technical Report RMRS-GTR-42-vol.4. Ogden, UT: U.S. Department of Agriculture, Forest Service, Rocky Mountain Research Station, p. 250.

Ostler, W.K. and D.J Hansen, 2001. In: McArthur, E.D. and D.J. Fairbanks, (ed.) Shrubland ecosystem genetics and biodiversity: Proceedings; 2000 June 13-15. Proc. RMRS-P-21. Ogden, UT: U.S. Department of Agriculture, Forest Service, Rocky Mountain Research Station, p. 365.

Powell, R.M., B.W. Bledsoe, R.I. Johnson, and G.P. Curtis, 1989. Interlaboratory methods comparison for the total organic carbon analysis of aquifer materials. Environmental Science \& Technology, 23:1246-1249.

Prandtl, L., 1963. The Essentials of Fluid Dynamics. Blackie \& Sons, Limited.

Reynolds, W.D., D.E. Elrick, E.G. Youngs, A. Amoozegar, H.W.G. Booltink, and J. Bouma, 2002. Saturated and field-saturated water flow parameters. In Dane, J.H. and G.C. Topp (ed.) Methods of Soil Analysis, Part 4, Physical Methods, Soil Science Society of America, Inc., Madison, WI. pp. 797-843.

Sankey, J., J. Eitell, N. Glenn, M. Germino, and L. Vierling, 2011. Quantifying relationships of burning, roughness, and potential dust emission with laser altimetry of soil surfaces at submeter scales. Geomorphology, 135:181-190.

Schoeneberger, P.J., D.A.W. Wysocki, E.C. Benham, and Soil Survey Staff, 2012. Field Book for Describing and Sampling Soils, Version 3.0. Natural Resources Conservation Service, National Soil Survey Center, Lincoln, NE.

Shafer, D.S., D. DuBois, V. Etyemezian, J. Xu, I. Kavouras, J. Miller, G. Nikolich, and M. Stone, 2007. Fire as a long term stewardship issue for soils contaminated with radionuclides in the western United States. Proceedings of the $11^{\text {th }}$ International Conference on Environmental Remediation and Radioactive Waste Management. Bruges, Belgium.

Shafer, D.S. and J. Gomes, 2009. Plant mounds as concentration and stabilization agents for actinides in soil. Proceedings of Waste Management 2009, 49 (4) Phoenix, AZ.

Shafer, D.S., V. Etyemezian, K. Chief, D. DuBois, I. Kavouras, J. King, J. Miller, G. Nikolich, and S.F. Zitzer, 2010. Ecological and physical response and feedbacks to fires in western North American deserts. Proceedings of the 10th International Conference on Dry Lands Development. Cairo, Egypt. 
Springer, D.S., S.J. Cullen, and L.G. Everett, 1995. Laboratory studies on air permeability. In L.G. Everett and S.J. Cullen (ed.), Handbook of Vadose Zone Characterization and Monitoring. Lewis Publishing, Boca Raton, FL, pp. 217-248.

Thompson, J. and B. MacFarlan, 2007. Gleason Creek and Smith Valley watersheds. Ecological Restoration Project Report. Eastern Nevada Landscape Coalition. Ely, NV.

U.S. Army Corps of Engineers, 2000. Hydrologic Modeling System HEC-HMS - Technical Reference Manual, U.S. Army Corps of Engineers, Hydrologic Engineering Center, Davis, CA.

U.S. Department of Agriculture, National Resources Conservation Service, 2012. The PLANTS database. Online. Available at http://plants.usda.gov. (2012).

U.S. Department of Agriculture, Soil Conservation Service, 1986. National Engineering Handbook - Section 4, Hydrology. National Technical Information Service, Washington, D.C.

U.S. Environmental Protection Agency, 2006. Level III ecoregions of the continental United States (revision of Omernik, 1987): Corvallis, Oregon, USEPA - National Health and Environmental Effects Research Laboratory, Map M-1, various scales.

Wooding, R.A., 1968. Steady infiltration from a shallow circular pond. Water Resources Research, 4(6):1259-1273. 


\section{APPENDIX A: $\quad$ SAMPLING DATES}

Table A-1. Sampling dates for the Gleason Fire site. $\mathrm{MAB}=$ months after burn, Wind $=$ PI-SWERL and related measurements, Water $=$ soil measurements and rainfall simulations, Vegetation $=$ vegetation surveys.

\begin{tabular}{|c|c|c|c|c|c|c|}
\hline Month & Month & Year & $M A B$ & \multirow[t]{2}{*}{ Wind } & \multirow[t]{2}{*}{ Water } & \multirow[t]{2}{*}{ Vegetation } \\
\hline 8 & 13-Aug & 2009 & FIRE & & & \\
\hline 8 & Aug & 2009 & 0 & $X$ & $X$ & \\
\hline 9 & Sept & 2009 & 1 & & & \\
\hline 10 & Oct & 2009 & 2 & & & \\
\hline 11 & Nov & 2009 & 3 & & & \\
\hline 12 & Dec & 2009 & 4 & & & \\
\hline 1 & Jan & 2010 & 5 & & & \\
\hline 2 & Feb & 2010 & 6 & & & \\
\hline 3 & Mar & 2010 & 7 & & & \\
\hline 4 & Apr & 2010 & 8 & & & \\
\hline 5 & May & 2010 & 9 & $\mathrm{X}$ & & \\
\hline 6 & Jun & 2010 & 10 & $X$ & $X$ & \\
\hline 7 & Jul & 2010 & 11 & & & \\
\hline 8 & Aug & 2010 & 12 & $X$ & $X$ & \\
\hline 9 & Sept & 2010 & 13 & & & $X$ \\
\hline 10 & Oct & 2010 & 14 & & & \\
\hline 11 & Nov & 2010 & 15 & & & \\
\hline 12 & Dec & 2010 & 16 & & & \\
\hline 1 & Jan & 2011 & 17 & & & \\
\hline 2 & Feb & 2011 & 18 & & & \\
\hline 3 & Mar & 2011 & 19 & & & \\
\hline 4 & Apr & 2011 & 20 & & & \\
\hline 5 & May & 2011 & 21 & $X$ & & \\
\hline 6 & Jun & 2011 & 22 & & $X$ & $X$ \\
\hline 7 & Jul & 2011 & 23 & & & \\
\hline 8 & Aug & 2011 & 24 & $X$ & & \\
\hline 9 & Sept & 2011 & 25 & & $X$ & \\
\hline 10 & Oct & 2011 & 26 & & & \\
\hline 11 & Nov & 2011 & 27 & & & \\
\hline 12 & Dec & 2011 & 28 & & & \\
\hline 1 & Jan & 2012 & 29 & & & \\
\hline 2 & Feb & 2012 & 30 & & & \\
\hline 3 & Mar & 2012 & 31 & & & \\
\hline 4 & Apr & 2012 & 32 & & & \\
\hline 5 & May & 2012 & 33 & & & \\
\hline 6 & Jun & 2012 & 34 & $X$ & $X$ & $X$ \\
\hline
\end{tabular}




\section{APPENDIX B: $\quad$ SOIL MEASUREMENT SITES}

Table B-1. Soil measurement sites, locations, and descriptions at the Gleason Fire site, 2009 - 2012. $\mathrm{UB}=$ unburned (pre-burn), $\mathrm{CT}=$ control (unburned), $\mathrm{BR}=$ burn.

\begin{tabular}{|c|c|c|c|c|c|c|c|c|}
\hline Transect & Site & Date & MAB & $\begin{array}{c}\mathbf{E} \\
(\mathbf{m})\end{array}$ & $\begin{array}{c}\mathbf{N} \\
(\mathbf{m})\end{array}$ & $\begin{array}{l}\begin{array}{l}\text { Elev } \\
(\mathbf{m})\end{array} \\
\end{array}$ & $\begin{array}{c}\text { Timing } \\
\text { (Pre/Post fire) } \\
\end{array}$ & $\begin{array}{l}\text { Treatment area } \\
\text { (Burn/Unburn) }\end{array}$ \\
\hline 1 & UB1 & 80409 & -0.13 & 668494 & 4362085 & 2195 & Pre & Burn \\
\hline 1 & UB2 & 80409 & -0.13 & 668497 & 4362088 & 2197 & Pre & Burn \\
\hline 1 & UB3 & 80409 & -0.13 & 668493 & 4362108 & 2196 & Pre & Burn \\
\hline 1 & UB4 & 80409 & -0.13 & 668492 & 4362122 & 2201 & Pre & Burn \\
\hline 1 & UB5 & 80409 & -0.13 & 668486 & 4362135 & 2203 & Pre & Burn \\
\hline 1 & CT1 & 80409 & -0.13 & 668574 & 4361997 & 2201 & Pre & Unburn \\
\hline 1 & $\mathrm{CT} 2$ & 80409 & -0.13 & 668580 & 4361982 & 2207 & Pre & Unburn \\
\hline $2 *$ & BR1 & 81809 & 0.17 & 668493 & 4362085 & & Post & Burn \\
\hline $2^{*}$ & BR2 & 81809 & 0.17 & 668493.6 & 4362088 & & Post & Burn \\
\hline $2 *$ & BR3 & 81809 & 0.17 & 668490.7 & 4362108 & & Post & Burn \\
\hline $2 *$ & BR4 & 81809 & 0.17 & 668489.5 & 4362122 & & Post & Burn \\
\hline $2^{*}$ & BR5 & 81809 & 0.17 & 668484.4 & 4362135 & & Post & Burn \\
\hline $2 *$ & CT3 & 81809 & 0.17 & 668572.3 & 4361997 & & Post & Unburn \\
\hline $2^{*}$ & CT4 & 81809 & 0.17 & 668577.8 & 4361982 & & Post & Unburn \\
\hline 3 & BR6 & 40330 & 10 & 668491 & 4362092 & 2201 & Post & Burn \\
\hline 3 & BR7 & 40330 & 10 & 668490 & 4362102 & 2199 & Post & Burn \\
\hline 3 & BR8 & 40330 & 10 & 668483 & 4362102 & 2210 & Post & Burn \\
\hline 3 & BR9 & 40330 & 10 & 668485 & 4362114 & & Post & Burn \\
\hline 3 & BR10 & 40330 & 10 & 668487 & 4362119 & & Post & Burn \\
\hline 3 & CT5 & 40330 & 10 & 668572 & 4361995 & 2193 & Post & Unburn \\
\hline 3 & CT6 & 40330 & 10 & 668568 & 4361984 & & Post & Unburn \\
\hline 4 & BR11 & aug/sep 10 & 12 & 668383 & 4361989 & 2110 & Post & Burn \\
\hline 4 & BR12 & aug/sep 10 & 12 & 668382 & 4361991 & 2113 & Post & Burn \\
\hline 4 & BR13 & aug/sep 10 & 12 & 668383 & 4361993 & 2131 & Post & Burn \\
\hline 4 & BR14 & aug/sep 10 & 12 & 668382 & 4361998 & 2199 & Post & Burn \\
\hline 4 & BR15 & aug/sep 10 & 12 & 668384 & 4362003 & 2202 & Post & Burn \\
\hline 4 & CT7 & aug/sep 10 & 12 & 668372 & 4362013 & 2171 & Post & Unburn \\
\hline 4 & CT8 & aug/sep 10 & 12 & 668370 & 4362015 & 2145 & Post & Unburn \\
\hline 5 & BR16 & 60711 & 22 & 668371 & 4362003 & & Post & Burn \\
\hline 5 & BR17B & 60811 & 22 & 668364 & 4361995 & 2202 & Post & Burn \\
\hline 5 & BR18B & 60811 & 22 & 668365 & 4361991 & 2203 & Post & Burn \\
\hline 5 & BR19 & 60811 & 22 & 668365 & 4361987 & 2213 & Post & Burn \\
\hline 5 & BR20 & 60911 & 22 & 668366 & 4361985 & 2196 & Post & Burn \\
\hline 5 & СТ9 & 60911 & 22 & 668373 & 4362018 & 2192 & Post & Unburn \\
\hline 5 & CT10 & 60911 & 22 & 668366 & 4362020 & 2190 & Post & Unburn \\
\hline 6 & BR21B & 91511 & 25 & & & & Post & Burn \\
\hline 6 & BR22 & 91311 & 25 & 668354 & 4361975 & 2184 & Post & Burn \\
\hline 6 & BR23 & 91311 & 25 & 668354 & 4361980 & 2195 & Post & Burn \\
\hline 6 & BR24 & 91311 & 25 & 668355 & 4361983 & 2195 & Post & Burn \\
\hline 6 & BR25 & 91411 & 25 & 668354 & 4361989 & 2196 & Post & Burn \\
\hline 6 & CT11 & 91411 & 25 & 668354 & 4362011 & 2199 & Post & Unburn \\
\hline 6 & $\mathrm{CT} 12$ & 91511 & 25 & 668354 & 4362004 & 2196 & Post & Unburn \\
\hline 7 & BR26 & 62712 & 34 & 668351 & 4361970 & 2196 & Post & Burn \\
\hline 7 & BR27 & 62712 & 34 & 668345 & 4361971 & 2199 & Post & Burn \\
\hline 7 & BR28 & 62712 & 34 & 668350 & 4361979 & 2198 & Post & Burn \\
\hline 7 & BR29 & 62712 & 34 & 668352 & 4361991 & 2194 & Post & Burn \\
\hline 7 & BR30 & 62612 & 34 & 668349 & 4361989 & 2194 & Post & Burn \\
\hline 7 & CT13 & 62612 & 34 & 668349 & 4362000 & 2200 & Post & Unburn \\
\hline 7 & CT14 & 62612 & 34 & 668350 & 4362007 & 2196 & Post & Unburn \\
\hline
\end{tabular}

* Transect 2 is a post-fire resampling of Transect 1. 


\section{APPENDIX C: $\quad$ SOIL PROPERTIES}

The MDTI (mini disk tension infiltrometer) array consists of a maximum of eight tension infiltrometers (pressurized tubes) electronically linked to a central datalogger. All soil samples (soil moisture, bulk density, air permeability, etc.) were based on these tension infiltrometer placement points that, with the current cable system, could extend linearly for approximately three meters.

One transect was established and sampled for each site visit. Along the transect, seven MDTI array sites were located - five in the burned area, two in the unburned area-establishing a 56-point linear transect (40 [5 MDTI arrays x 8 tubes] points in the burned area, 16 [2 MDTI arrays $x 8$ tubes] in the unburned area). For each MDTI array, four tubes were located at interspace (i) sites, four at understory (c) sites.

The Gleason Fire occurred on August 13, 2009. The first soil sampling field visit took place August 4-5, 2009, four days before the prescribed fire (-0.13 MAB). The second soil sampling field visit took place on August 18-19, 2009, five days after the fire (0.16 MAB). The pre-burn transect (UB1-UB5, CT1-CT2) was marked and re-sampled after the fire (BR1-BR5,

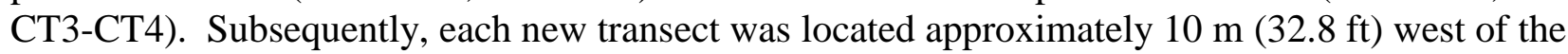
previous transect along the same slope. The transect movement was to avoid site disturbance (holes, sand pads, etc.) from the previous field visit.

The soil data were collected from beneath the infiltrometer after the test was complete and the instrument removed. Thus, the majority of the soil moisture $(w)$ samples are post-test (i.e., wet). However, the bulk density, porosity, and soil texture are constant soil properties measured after drying the soil. Beginning in June 2011, two pre-infiltrometer test soil samples were collected for each MDTI array - one at an interspace site, one at a canopy understory site - to ascertain the initial ambient soil moisture status at the time of the test. These data are indicated by "initial" added to the site ID. 
Table C-1. Measured soil properties for the Gleason Fire site, 2009-2012. MAB = months after burn, $\rho_{b}=$ bulk density, $f=$ porosity, $w=$ gravimetric soil moisture, $K_{s}=$ saturated hydraulic conductivity, $k_{a}=$ air permeability, WDPT $=$ water drop penetration time, $\mathrm{OM}=$ organic matter. A date of $-0.13 \mathrm{MAB}$ represents four days before the fire of August 13, 2009; 0.16 MAB represents five days after the fire. An entry of "n/a" means data were unavailable.

\begin{tabular}{|c|c|c|c|c|c|c|c|c|c|c|c|c|c|}
\hline $\begin{array}{c}\text { Date } \\
\text { (MAB) }\end{array}$ & ID & $\begin{array}{c}\rho_{b} \\
\left(\mathrm{~g} \mathrm{~cm}^{-3}\right)\end{array}$ & $\begin{array}{c}f \\
\left(\operatorname{vol~vol}^{-1}\right)\end{array}$ & $\begin{array}{c}w \\
\left(\mathrm{~g} \mathrm{~g}^{-1}\right)\end{array}$ & $\begin{array}{c}K_{s} \\
\left(\mathrm{~cm} \mathrm{hr}^{-1}\right)\end{array}$ & $\begin{array}{c}k_{a} \\
\left(\mu \mathrm{m}^{2}\right)\end{array}$ & $\begin{array}{c}\text { WDPT } \\
{[\mathrm{s}]}\end{array}$ & $\begin{array}{l}\text { ash } \\
{[\mathrm{cm}]}\end{array}$ & $\begin{array}{c}\text { Gravel } \\
{[\%]}\end{array}$ & $\begin{array}{l}\mathrm{OM} \\
{[\%]}\end{array}$ & $\begin{array}{c}\text { Sand } \\
{[\%]}\end{array}$ & $\begin{array}{l}\text { Silt } \\
{[\%]}\end{array}$ & $\begin{array}{l}\text { Clay } \\
{[\%]}\end{array}$ \\
\hline-0.13 & UB1-1c & 1.39 & 0.47 & 0.22 & 5.28 & 22.89 & 0.0 & 0.0 & 19.4 & 4.2 & 69.5 & 24.5 & 6.1 \\
\hline-0.13 & UB1-2i & 1.71 & 0.35 & 0.16 & 0.76 & 7.09 & 0.0 & 0.0 & 12.5 & 2.3 & 66.9 & 26.1 & 7.0 \\
\hline-0.13 & UB 1-3c & 1.53 & 0.42 & 0.16 & 4.34 & 9.02 & 0.0 & 0.0 & 13.5 & 2.4 & 68.8 & 24.6 & 6.5 \\
\hline-0.13 & UB $1-4 \mathrm{i}$ & 1.53 & 0.42 & 0.17 & 2.09 & 8.07 & 0.0 & 0.0 & 11.7 & 2.7 & 66.9 & 26.4 & 6.7 \\
\hline-0.13 & UB $1-5 c$ & 1.19 & 0.55 & 0.20 & 4.62 & 17.11 & 0.0 & 0.0 & 6.6 & 4.7 & 64.8 & 27.1 & 8.2 \\
\hline-0.13 & UB1-6i & 1.50 & 0.43 & 0.14 & 1.30 & 5.15 & 0.0 & 0.0 & 28.9 & 3.1 & 59.0 & 33.7 & 7.3 \\
\hline-0.13 & UB $1-7 \mathrm{c}$ & 1.05 & 0.61 & 0.17 & 5.78 & 15.72 & 0.0 & 0.0 & 1.8 & 5.1 & 65.3 & 27.0 & 7.7 \\
\hline-0.13 & UB1-8i & 1.71 & 0.36 & 0.15 & 0.80 & 6.20 & 0.0 & 0.0 & 31.6 & 2.4 & 46.5 & 44.4 & 9.0 \\
\hline-0.13 & UB2-1i & 1.60 & 0.40 & 0.16 & 0.58 & 8.73 & 0.0 & 0.0 & 19.9 & 2.6 & 70.8 & 21.6 & 7.5 \\
\hline-0.13 & UB2-2c & 1.49 & 0.44 & 0.18 & 5.46 & 14.12 & 0.0 & 0.0 & 14.3 & 2.8 & 72.0 & 21.2 & 6.8 \\
\hline-0.13 & UB2-3i & 1.62 & 0.39 & 0.17 & 0.26 & 52.44 & 0.0 & 0.0 & 14.0 & 2.8 & 53.1 & 35.9 & 11.0 \\
\hline-0.13 & UB2-4c & 1.58 & 0.41 & 0.20 & 4.27 & 16.74 & 0.0 & 0.0 & 7.4 & 3.3 & 62.2 & 27.9 & 9.8 \\
\hline-0.13 & UB2-5i & 1.63 & 0.38 & 0.14 & 0.71 & 9.32 & 0.0 & 0.0 & 13.9 & 2.1 & 59.1 & 33.6 & 7.3 \\
\hline-0.13 & UB2-6c & 1.25 & 0.53 & 0.15 & 4.82 & 16.67 & 0.0 & 0.0 & 5.5 & 3.7 & 72.3 & 20.7 & 6.9 \\
\hline-0.13 & UB2-7i & 1.66 & 0.37 & 0.16 & 0.90 & 17.94 & 0.0 & 0.0 & 27.7 & 3.3 & 52.1 & 35.8 & 12.0 \\
\hline-0.13 & UB2-8c & 1.31 & 0.51 & 0.25 & 1.63 & 14.01 & 0.0 & 0.0 & 6.1 & 3.3 & 81.5 & 14.0 & 4.5 \\
\hline-0.13 & UB3-1i & 1.55 & 0.41 & 0.14 & 0.63 & 34.16 & 0.0 & 0.0 & 24.5 & 2.4 & 60.8 & 30.2 & 8.9 \\
\hline-0.13 & UB3-2c & 1.24 & 0.53 & 0.21 & 3.01 & 50.83 & 0.0 & 0.0 & 4.6 & 4.2 & 66.0 & 25.3 & 8.7 \\
\hline-0.13 & UB3-3i & 1.53 & 0.42 & 0.15 & 0.50 & 9.72 & 0.0 & 0.0 & 10.0 & 2.5 & 50.5 & 39.4 & 10.1 \\
\hline-0.13 & UB3-4c & 1.47 & 0.45 & 0.16 & 2.01 & 41.52 & 0.0 & 0.0 & 12.7 & 2.7 & 56.3 & 33.4 & 10.4 \\
\hline-0.13 & UB3-5i & 1.37 & 0.48 & 0.13 & 0.76 & 17.29 & 0.0 & 0.0 & 8.8 & 2.6 & 43.1 & 41.7 & 15.2 \\
\hline-0.13 & UB3-6c & 1.43 & 0.46 & 0.24 & 9.97 & 24.71 & 0.0 & 0.0 & 2.7 & 2.6 & 51.8 & 38.2 & 9.9 \\
\hline-0.13 & UB3-7i & 1.64 & 0.38 & 0.16 & 0.41 & 13.83 & 0.0 & 0.0 & 10.5 & 3.0 & 52.4 & 36.4 & 11.2 \\
\hline-0.13 & UB3-8c & 1.38 & 0.48 & 0.20 & 4.71 & 17.15 & 0.0 & 0.0 & 6.8 & 3.7 & 63.5 & 27.6 & 8.9 \\
\hline-0.13 & UB4-1i & 1.48 & 0.44 & 0.12 & 1.33 & 28.04 & 0.0 & 0.0 & 17.4 & 2.6 & 64.6 & 28.5 & 6.9 \\
\hline-0.13 & UB4-2c & 1.27 & 0.52 & 0.17 & 6.83 & 32.04 & 0.0 & 0.0 & 4.3 & 3.5 & 73.0 & 20.7 & 6.3 \\
\hline-0.13 & UB4-3i & 1.54 & 0.42 & 0.14 & 0.26 & 9.01 & 0.0 & 0.0 & 15.7 & 2.5 & 59.5 & 32.9 & 7.7 \\
\hline-0.13 & UB4-4c & 1.72 & 0.35 & 0.18 & 8.05 & 26.22 & 0.0 & 0.0 & 33.1 & 3.0 & 57.7 & 31.9 & 10.4 \\
\hline-0.13 & UB4-5i & 1.45 & 0.45 & 0.18 & 0.75 & 18.80 & 0.0 & 0.0 & 10.4 & 2.1 & 53.8 & 38.3 & 7.9 \\
\hline-0.13 & UB4-6c & 1.34 & 0.49 & 0.09 & 2.97 & 18.44 & 0.0 & 0.0 & 10.1 & 3.2 & 60.0 & 31.3 & 8.8 \\
\hline-0.13 & UB4-7i & 1.58 & 0.40 & 0.16 & 1.46 & 10.00 & 0.0 & 0.0 & 24.9 & 2.9 & 61.8 & 30.1 & 8.0 \\
\hline
\end{tabular}


Table C-1. Measured soil properties for the Gleason Fire site, 2009-2012. MAB = months after burn, $\rho_{b}=$ bulk density, $f=$ porosity, $w=$ gravimetric soil moisture, $K_{s}=$ saturated hydraulic conductivity, $k_{a}=$ air permeability, WDPT $=$ water drop penetration time, $\mathrm{OM}=$ organic matter. A date of $-0.13 \mathrm{MAB}$ represents four days before the fire of August 13, 2009; 0.16 MAB represents five days after the fire. An entry of "n/a" means data were unavailable (continued).

\begin{tabular}{|c|c|c|c|c|c|c|c|c|c|c|c|c|c|}
\hline $\begin{array}{c}\text { Date } \\
(\mathrm{MAB})\end{array}$ & ID & $\begin{array}{c}\rho_{b} \\
\left(\mathrm{~g} \mathrm{~cm}^{-3}\right)\end{array}$ & $\begin{array}{c}f \\
\left(\mathrm{vol} \mathrm{vol}^{-1}\right)\end{array}$ & $\begin{array}{c}w \\
\left(\mathrm{~g} \mathrm{~g}^{-1}\right)\end{array}$ & $\begin{array}{c}K_{s} \\
\left(\mathrm{~cm} \mathrm{hr}^{-1}\right)\end{array}$ & $\begin{array}{c}k_{a} \\
\left(\mu \mathrm{m}^{2}\right)\end{array}$ & $\begin{array}{c}\text { WDPT } \\
{[\mathrm{s}]}\end{array}$ & $\begin{array}{c}\text { ash } \\
{[\mathrm{cm}]}\end{array}$ & $\begin{array}{c}\text { Gravel } \\
{[\%]}\end{array}$ & $\begin{array}{l}\mathrm{OM} \\
{[\%]}\end{array}$ & $\begin{array}{c}\text { Sand } \\
{[\%]}\end{array}$ & $\begin{array}{l}\text { Silt } \\
{[\%]}\end{array}$ & $\begin{array}{l}\text { Clay } \\
{[\%]}\end{array}$ \\
\hline-0.13 & UB4-8c & 1.36 & 0.49 & 0.30 & 6.91 & 12.15 & 0.0 & 0.0 & 32.0 & 3.9 & 70.0 & 23.7 & 6.2 \\
\hline-0.13 & UB5-1i & 1.58 & 0.40 & 0.23 & 1.23 & 7.49 & 0.0 & 0.0 & 10.3 & 2.5 & 56.2 & 33.6 & 10.3 \\
\hline-0.13 & UB5-2c & 1.35 & 0.49 & 0.22 & 1.96 & 23.34 & 0.0 & 0.0 & 12.0 & 2.7 & 71.0 & 21.8 & 7.1 \\
\hline-0.13 & UB5-3i & 1.65 & 0.38 & 0.23 & 0.46 & 10.84 & 0.0 & 0.0 & 25.1 & 2.6 & 56.1 & 34.3 & 9.6 \\
\hline-0.13 & UB5-4c & 1.52 & 0.43 & 0.30 & 3.69 & 21.97 & 0.0 & 0.0 & 15.2 & 3.0 & 63.8 & 27.7 & 8.5 \\
\hline-0.13 & UB5-5i & 1.46 & 0.45 & 0.19 & 1.02 & 13.40 & 0.0 & 0.0 & 16.5 & 2.7 & 63.4 & 28.2 & 8.4 \\
\hline-0.13 & UB5-6c & 1.01 & 0.62 & 0.26 & 3.74 & 30.16 & 0.0 & 0.0 & 6.6 & 5.6 & 69.0 & 24.0 & 7.0 \\
\hline-0.13 & UB5-7i & 1.55 & 0.42 & 0.21 & 0.95 & 30.05 & 0.0 & 0.0 & 21.1 & 2.8 & 69.3 & 24.1 & 6.5 \\
\hline-0.13 & UB5-8c & 1.35 & 0.49 & 0.27 & 1.77 & 30.05 & 0.0 & 0.0 & 8.4 & 3.3 & 63.6 & 28.7 & 7.7 \\
\hline-0.13 & CT1-1c & 2.02 & 0.24 & 0.16 & 2.66 & 32.61 & 0.0 & 0.0 & 51.0 & 1.9 & 74.1 & 19.9 & 6.0 \\
\hline-0.13 & CT1-2i & 1.60 & 0.40 & 0.24 & 1.13 & 21.11 & 0.0 & 0.0 & 5.0 & 2.4 & 64.5 & 28.0 & 7.5 \\
\hline-0.13 & CT1-3c & 1.46 & 0.45 & 0.25 & 1.95 & 9.78 & 0.0 & 0.0 & 7.1 & 3.0 & 64.4 & 27.7 & 7.8 \\
\hline-0.13 & CT1-4i & 1.25 & 0.53 & 0.23 & 4.38 & 8.82 & 0.0 & 0.0 & 14.9 & 3.3 & 71.7 & 22.4 & 6.0 \\
\hline-0.13 & CT1-5c & 1.64 & 0.38 & 0.22 & 1.47 & 91.35 & 0.0 & 0.0 & 12.1 & 2.3 & 59.2 & 32.8 & 8.0 \\
\hline-0.13 & CT1-6i & 1.47 & 0.45 & 0.25 & 3.40 & 17.98 & 0.0 & 0.0 & 17.3 & 3.1 & 69.6 & 23.2 & 7.2 \\
\hline-0.13 & CT1-7c & 1.62 & 0.39 & 0.22 & 0.30 & 19.16 & 0.0 & 0.0 & 10.4 & 2.3 & 49.7 & 41.3 & 9.0 \\
\hline-0.13 & CT1-8i & 1.31 & 0.50 & 0.33 & 6.67 & 5.91 & 0.0 & 0.0 & 6.4 & 3.6 & 62.2 & 28.8 & 9.0 \\
\hline-0.13 & CT2-1c & 1.54 & 0.42 & 0.23 & 3.50 & 12.19 & 0.0 & 0.0 & 9.4 & 2.1 & 70.1 & 23.3 & 6.6 \\
\hline-0.13 & CT2-2i & 1.49 & 0.44 & 0.17 & 0.83 & 7.78 & 0.0 & 0.0 & 19.8 & 2.2 & 61.1 & 30.9 & 8.0 \\
\hline-0.13 & СТ2-3c & 1.28 & 0.52 & 0.08 & 2.37 & 13.85 & 0.0 & 0.0 & 8.0 & 2.9 & 63.1 & 29.5 & 7.5 \\
\hline-0.13 & CT2-4i & 1.46 & 0.45 & 0.22 & 0.68 & 9.01 & 0.0 & 0.0 & 6.8 & 2.3 & 65.2 & 26.2 & 8.5 \\
\hline-0.13 & CT2-5c & 1.19 & 0.55 & 0.23 & 3.28 & 17.62 & 0.0 & 0.0 & 18.6 & 4.0 & 62.9 & 28.0 & 9.1 \\
\hline-0.13 & CT2-6i & 1.61 & 0.39 & 0.13 & 1.05 & 6.57 & 0.0 & 0.0 & 13.6 & 1.9 & 72.6 & 21.8 & 5.6 \\
\hline-0.13 & СТ2-7c & 1.48 & 0.44 & 0.17 & 5.94 & 10.67 & 0.0 & 0.0 & 13.1 & 3.0 & 73.8 & 20.3 & 5.9 \\
\hline-0.13 & CT2-8i & 1.67 & 0.37 & 0.16 & 1.30 & 5.23 & 0.0 & 0.0 & 7.7 & 1.9 & 61.9 & 31.8 & 6.3 \\
\hline 0.16 & BR1-1i & 1.33 & 0.50 & 0.22 & 4.10 & 17.43 & 0.0 & 0.0 & 3.7 & 2.8 & 75.2 & 19.3 & 5.5 \\
\hline 0.16 & BR1-2c & 1.46 & 0.45 & 0.18 & 0.99 & 16.20 & 0.0 & 0.0 & 7.7 & 2.0 & 59.6 & 32.2 & 8.2 \\
\hline 0.16 & BR1-3c & 1.20 & 0.55 & 0.17 & 4.14 & 14.55 & 0.0 & 0.0 & 11.4 & 2.8 & 75.2 & 18.7 & 6.1 \\
\hline 0.16 & BR1-4c & 1.35 & 0.49 & 0.25 & 5.94 & 31.06 & 0.0 & 0.0 & 2.3 & 2.9 & 71.2 & 22.4 & 6.5 \\
\hline 0.16 & BR1-5i & 1.26 & 0.52 & 0.20 & 2.54 & 13.17 & 0.0 & 0.0 & 4.9 & 3.3 & 70.9 & 22.6 & 6.5 \\
\hline 0.16 & BR1-6i & 1.52 & 0.43 & 0.20 & 0.78 & 5.60 & 0.0 & 0.0 & 4.9 & 2.3 & 56.1 & 35.4 & 8.6 \\
\hline
\end{tabular}


Table C-1. Measured soil properties for the Gleason Fire site, 2009-2012. MAB = months after burn, $\rho_{b}=$ bulk density, $f=$ porosity, $w=$ gravimetric soil moisture, $K_{s}=$ saturated hydraulic conductivity, $k_{a}=$ air permeability, WDPT $=$ water drop penetration time, $\mathrm{OM}=$ organic matter. A date of $-0.13 \mathrm{MAB}$ represents four days before the fire of August 13, 2009; 0.16 MAB represents five days after the fire. An entry of "n/a" means data were unavailable (continued).

\begin{tabular}{|c|c|c|c|c|c|c|c|c|c|c|c|c|c|}
\hline $\begin{array}{c}\text { Date } \\
(\mathrm{MAB})\end{array}$ & ID & $\begin{array}{c}\rho_{b} \\
\left(\mathrm{~g} \mathrm{~cm}^{-3}\right)\end{array}$ & $\begin{array}{c}f \\
\left(\mathrm{vol} \mathrm{vol}^{-1}\right)\end{array}$ & $\begin{array}{c}w \\
\left(\mathrm{~g} \mathrm{~g}^{-1}\right)\end{array}$ & $\begin{array}{c}K_{s} \\
\left(\mathrm{~cm} \mathrm{hr}^{-1}\right)\end{array}$ & $\begin{array}{c}k_{a} \\
\left(\mu \mathrm{m}^{2}\right)\end{array}$ & $\begin{array}{c}\text { WDPT } \\
{[\mathrm{s}]}\end{array}$ & $\begin{array}{c}\text { ash } \\
{[\mathrm{cm}]}\end{array}$ & $\begin{array}{c}\text { Gravel } \\
{[\%]}\end{array}$ & $\begin{array}{l}\mathrm{OM} \\
{[\%]}\end{array}$ & $\begin{array}{c}\text { Sand } \\
{[\%]}\end{array}$ & $\begin{array}{l}\text { Silt } \\
{[\%]}\end{array}$ & $\begin{array}{l}\text { Clay } \\
{[\%]}\end{array}$ \\
\hline 0.16 & BR1-7i & 1.54 & 0.42 & 0.17 & 0.55 & 10.22 & 0.0 & 0.0 & 16.1 & 2.0 & 69.7 & 23.5 & 6.8 \\
\hline 0.16 & BR1-8c & 1.58 & 0.40 & 0.16 & 0.78 & 8.07 & 0.0 & 0.0 & 18.9 & 2.0 & 66.8 & 26.0 & 7.2 \\
\hline 0.16 & BR2-1c & 1.64 & 0.38 & 0.20 & 0.02 & 12.35 & 0.0 & 0.0 & 15.5 & 1.7 & 66.0 & 28.4 & 5.7 \\
\hline 0.16 & BR2-2i & 1.51 & 0.43 & 0.19 & 0.58 & 11.16 & 0.0 & 0.0 & 10.8 & 1.5 & 56.8 & 37.1 & 6.1 \\
\hline 0.16 & BR2-3c & 1.55 & 0.42 & 0.21 & 0.01 & 16.61 & 0.0 & 0.0 & 8.1 & 1.9 & 55.7 & 37.3 & 7.0 \\
\hline 0.16 & BR2-4c & 1.29 & 0.51 & 0.16 & 2.04 & 19.85 & 0.0 & 0.0 & 15.5 & 2.2 & 71.7 & 22.6 & 5.7 \\
\hline 0.16 & BR2-5i & 1.49 & 0.44 & 0.20 & 0.01 & 10.52 & 0.0 & 0.0 & 8.8 & 1.7 & 61.0 & 31.6 & 7.4 \\
\hline 0.16 & BR2-6i & 1.44 & 0.46 & 0.22 & 1.94 & 24.21 & 0.0 & 0.0 & 6.1 & 2.3 & 64.1 & 27.7 & 8.3 \\
\hline 0.16 & BR2-7c & 1.04 & 0.61 & 0.24 & 14.24 & 13.20 & 0.0 & 0.0 & 3.1 & 3.3 & 80.5 & 16.2 & 3.4 \\
\hline 0.16 & BR2-8c & 1.52 & 0.43 & 0.18 & 0.02 & 21.73 & 0.0 & 0.0 & 10.4 & 1.6 & 72.0 & 22.7 & 5.3 \\
\hline 0.16 & BR3-1c & 1.15 & 0.57 & 0.10 & 1.60 & 9.45 & 5.0 & 0.0 & 10.2 & 3.2 & 49.5 & 39.6 & 11.0 \\
\hline 0.16 & BR3-2i & 1.16 & 0.56 & 0.14 & 4.99 & 16.79 & 70.0 & 6.5 & 8.2 & 3.4 & 65.9 & 26.3 & 7.8 \\
\hline 0.16 & BR3-3c & 1.16 & 0.56 & 0.15 & 5.72 & 21.61 & 300.0 & 3.0 & 7.7 & 3.4 & 57.0 & 32.8 & 10.2 \\
\hline 0.16 & BR3-4c & 0.95 & 0.64 & 0.08 & 6.68 & 31.57 & 202.5 & 5.0 & 8.5 & 4.8 & 60.3 & 30.3 & 9.2 \\
\hline 0.16 & BR3-5i & 1.17 & 0.56 & 0.11 & 1.77 & 11.27 & 5.0 & 0.0 & 13.5 & 3.9 & 56.8 & 33.0 & 10.2 \\
\hline 0.16 & BR3-6i & 1.18 & 0.56 & 0.08 & 1.25 & 12.67 & 5.0 & 0.0 & 27.9 & 3.4 & 56.2 & 34.0 & 9.7 \\
\hline 0.16 & BR3-7i & 1.18 & 0.56 & 0.16 & 4.00 & 52.95 & 5.0 & 0.0 & 7.8 & 3.8 & 56.5 & 34.2 & 9.2 \\
\hline 0.16 & BR3-8c & 1.11 & 0.58 & 0.12 & 4.59 & 27.19 & 60.0 & 0.5 & 18.6 & 3.9 & 55.5 & 35.4 & 9.1 \\
\hline 0.16 & BR4-1c & 1.25 & 0.53 & 0.21 & 4.52 & 26.31 & 8.0 & 2.0 & 14.5 & 2.7 & 72.8 & 20.8 & 6.4 \\
\hline 0.16 & BR4-2c & 1.31 & 0.51 & 0.23 & 0.05 & 25.26 & 3.0 & 0.0 & 2.3 & 2.9 & 51.7 & 36.0 & 12.2 \\
\hline 0.16 & BR4-3i & 1.24 & 0.53 & 0.21 & 4.10 & 26.13 & 3.0 & 2.0 & 2.9 & 2.9 & 63.5 & 27.8 & 8.7 \\
\hline 0.16 & BR4-4i & 1.29 & 0.51 & 0.27 & 1.53 & 29.15 & 15.0 & 4.0 & 3.5 & 2.9 & 76.5 & 16.8 & 6.7 \\
\hline 0.16 & BR4-5c & 1.19 & 0.55 & 0.14 & 1.72 & 26.04 & 3.0 & 0.0 & 8.8 & 2.7 & 58.2 & 33.6 & 8.1 \\
\hline 0.16 & BR4-6c & 1.31 & 0.51 & 0.18 & 0.50 & 13.54 & 2.0 & 0.0 & 8.1 & 2.9 & 55.2 & 35.4 & 9.4 \\
\hline 0.16 & BR4-7i & 1.13 & 0.57 & 0.20 & 1.87 & 14.12 & 5.0 & 2.0 & 3.1 & 3.3 & 66.0 & 25.0 & 8.9 \\
\hline 0.16 & BR4-8i & 0.72 & 0.73 & 0.19 & 4.27 & 9.63 & 55.0 & 3.0 & 13.0 & 7.9 & 57.4 & 33.7 & 8.9 \\
\hline 0.16 & BR5-1c & 1.17 & 0.56 & 0.29 & 7.50 & 126.27 & 117.0 & 0.5 & 19.0 & 3.7 & 62.9 & 27.5 & 9.6 \\
\hline 0.16 & BR5-2c & 1.39 & 0.48 & 0.23 & 0.91 & 28.42 & 2.0 & 0.0 & 9.6 & 3.3 & 58.9 & 32.2 & 8.9 \\
\hline 0.16 & BR5-3c & 1.16 & 0.56 & 0.32 & 2.14 & 30.46 & 360.0 & 3.0 & 3.6 & 4.9 & 63.3 & 28.5 & 8.2 \\
\hline 0.16 & BR5-4c & 0.89 & 0.67 & 0.26 & 5.38 & 21.61 & 360.0 & 3.0 & 35.3 & 7.3 & 57.1 & 34.5 & 8.4 \\
\hline 0.16 & BR5-5i & 1.32 & 0.50 & 0.19 & 0.66 & 16.42 & 3.0 & 0.1 & 6.9 & 2.9 & 66.1 & 26.7 & 7.1 \\
\hline
\end{tabular}


Table C-1. Measured soil properties for the Gleason Fire site, 2009-2012. MAB = months after burn, $\rho_{b}=$ bulk density, $f=$ porosity, $w=$ gravimetric soil moisture, $K_{s}=$ saturated hydraulic conductivity, $k_{a}=$ air permeability, WDPT $=$ water drop penetration time, $\mathrm{OM}=$ organic matter. A date of $-0.13 \mathrm{MAB}$ represents four days before the fire of August 13, 2009; 0.16 MAB represents five days after the fire. An entry of " $\mathrm{n} / \mathrm{a}$ " means data were unavailable (continued).

\begin{tabular}{|c|c|c|c|c|c|c|c|c|c|c|c|c|c|}
\hline $\begin{array}{c}\text { Date } \\
(\mathrm{MAB})\end{array}$ & ID & $\begin{array}{c}\rho_{b} \\
\left(\mathrm{~g} \mathrm{~cm}^{-3}\right)\end{array}$ & $\begin{array}{c}f \\
\left(\mathrm{vol} \mathrm{vol}^{-1}\right)\end{array}$ & $\begin{array}{c}w \\
\left(\mathrm{~g} \mathrm{~g}^{-1}\right)\end{array}$ & $\begin{array}{c}K_{s} \\
\left(\mathrm{~cm} \mathrm{hr}^{-1}\right)\end{array}$ & $\begin{array}{c}k_{a} \\
\left(\mu \mathrm{m}^{2}\right)\end{array}$ & $\begin{array}{c}\text { WDPT } \\
{[\mathrm{s}]}\end{array}$ & $\begin{array}{c}\text { ash } \\
{[\mathrm{cm}]}\end{array}$ & $\begin{array}{c}\text { Gravel } \\
{[\%]}\end{array}$ & $\begin{array}{l}\mathrm{OM} \\
{[\%]}\end{array}$ & $\begin{array}{c}\text { Sand } \\
{[\%]}\end{array}$ & $\begin{array}{l}\text { Silt } \\
{[\%]}\end{array}$ & $\begin{array}{l}\text { Clay } \\
{[\%]}\end{array}$ \\
\hline 0.16 & BR5-6i & 1.26 & 0.52 & 0.19 & 1.27 & 15.50 & 1.0 & 0.1 & 19.1 & 3.0 & 62.7 & 29.2 & 8.0 \\
\hline 0.16 & BR5-7i & 1.42 & 0.47 & 0.18 & 1.85 & 13.60 & 1.0 & 0.0 & 15.5 & 2.0 & 59.9 & 33.1 & 7.1 \\
\hline 0.16 & BR5-8i & 1.35 & 0.49 & 0.16 & 2.09 & 27.05 & 5.0 & 0.3 & 21.9 & 2.0 & 75.0 & 20.1 & 4.9 \\
\hline 0.16 & CT3-1c & 1.40 & 0.47 & 0.20 & 3.26 & 21.40 & 2.0 & 0.2 & 1.8 & 2.4 & 71.2 & 22.7 & 6.2 \\
\hline 0.16 & СТ3-2i & 1.22 & 0.54 & 0.26 & 4.10 & 19.80 & 360.0 & 1.0 & 36.5 & 3.4 & 67.5 & 26.2 & 6.4 \\
\hline 0.16 & СТ3-3c & 1.32 & 0.50 & 0.17 & 1.53 & 9.11 & 10.0 & 0.0 & 33.2 & 2.9 & 64.3 & 28.2 & 7.5 \\
\hline 0.16 & СТ3-4c & 1.37 & 0.48 & 0.16 & 1.83 & 21.68 & 3.0 & 0.0 & 33.1 & 2.5 & 61.4 & 30.6 & 7.8 \\
\hline 0.16 & СТ3-5c & 1.46 & 0.45 & 0.17 & 1.45 & 21.68 & 5.0 & 0.1 & 31.1 & 2.9 & 65.0 & 28.1 & 6.9 \\
\hline 0.16 & СТ3-6i & 1.40 & 0.47 & 0.19 & 3.58 & 30.36 & 5.0 & 0.2 & 13.1 & 2.3 & 67.6 & 26.1 & 6.2 \\
\hline 0.16 & СТ3-7i & 1.34 & 0.49 & 0.20 & 1.66 & 27.60 & 2.0 & 0.0 & 5.6 & 2.7 & 66.7 & 25.4 & 7.8 \\
\hline 0.16 & СТ3-8i & 1.35 & 0.49 & 0.20 & 1.62 & 19.29 & 1.0 & 0.0 & 19.4 & 3.1 & 63.1 & 27.3 & 9.6 \\
\hline 0.16 & CT4-1i & 1.20 & 0.55 & 0.26 & 6.81 & 14.64 & 5.0 & 0.5 & 6.4 & 3.8 & 65.8 & 25.3 & 8.9 \\
\hline 0.16 & CT4-2i & 1.11 & 0.58 & 0.20 & 5.72 & 23.66 & 120.0 & 3.0 & 6.6 & 3.1 & 64.0 & 26.6 & 9.5 \\
\hline 0.16 & CT4-3c & 1.10 & 0.59 & 0.25 & 10.88 & 43.20 & 15.0 & 2.0 & 13.1 & 4.6 & 62.2 & 29.6 & 8.2 \\
\hline 0.16 & CT4-4c & 1.02 & 0.62 & 0.15 & 5.99 & 34.16 & 5.0 & 3.0 & 9.6 & 3.8 & 67.3 & 24.8 & 7.9 \\
\hline 0.16 & CT4-5i & 1.28 & 0.52 & 0.16 & 2.24 & 15.13 & 1.0 & 0.0 & 12.9 & 2.8 & 75.5 & 18.4 & 6.1 \\
\hline 0.16 & CT4-6c & 1.41 & 0.47 & 0.16 & 2.25 & 19.85 & 1.0 & 0.0 & 13.5 & 2.4 & 62.8 & 29.6 & 7.6 \\
\hline 0.16 & CT4-7c & 1.55 & 0.41 & 0.17 & 1.10 & 18.38 & 1.0 & 0.0 & 16.5 & 1.8 & 62.6 & 31.8 & 5.7 \\
\hline 0.16 & CT4-8i & 1.45 & 0.45 & 0.16 & 2.35 & 13.50 & 3.0 & 0.0 & 13.1 & 2.5 & 65.1 & 27.1 & 7.8 \\
\hline 10 & BR6-1c & 1.34 & 0.49 & 0.11 & 3.98 & 20.17 & 114.0 & 2.0 & 16.7 & 3.5 & 51.3 & 39.0 & 9.7 \\
\hline 10 & BR6-2c & 1.23 & 0.53 & 0.09 & 0.01 & 8.86 & 1200.0 & 4.0 & 7.9 & 3.3 & 53.9 & 35.6 & 10.5 \\
\hline 10 & BR6-3i & 1.55 & 0.42 & 0.18 & 2.10 & 9.57 & 0.0 & 0.0 & 7.7 & 2.9 & 55.9 & 34.0 & 10.2 \\
\hline 10 & BR6-4i & 1.54 & 0.42 & 0.19 & 1.62 & 4.18 & 0.0 & 0.0 & 14.4 & 3.3 & 47.3 & 41.4 & 11.4 \\
\hline 10 & BR6-5i & 1.61 & 0.39 & 0.18 & 1.03 & 14.17 & 0.0 & 0.0 & 11.3 & 2.9 & 49.6 & 39.9 & 10.5 \\
\hline 10 & BR6-6i & 1.45 & 0.45 & 0.19 & 1.48 & 13.31 & 0.0 & 0.0 & 11.3 & 2.8 & 57.3 & 33.7 & 9.0 \\
\hline 10 & BR6-7c & 1.18 & 0.55 & 0.08 & 2.30 & 7.57 & 1200.0 & 2.0 & 8.8 & 2.9 & 60.8 & 29.6 & 9.6 \\
\hline 10 & BR6-8c & 1.22 & 0.54 & 0.08 & 4.55 & 12.74 & 1200.0 & 2.0 & 13.1 & 3.1 & 55.7 & 34.5 & 9.8 \\
\hline 10 & BR7-1c & 1.35 & 0.49 & 0.13 & 2.17 & 13.82 & 21.0 & 2.0 & 6.2 & 3.0 & 52.5 & 38.0 & 9.5 \\
\hline 10 & BR7-2c & 1.41 & 0.47 & 0.09 & 1.05 & 6.89 & 1.3 & 1.5 & 7.7 & 3.0 & 62.1 & 28.2 & 9.7 \\
\hline 10 & BR7-3i & 1.51 & 0.43 & 0.11 & 1.50 & 15.19 & 6.0 & 0.0 & 14.8 & 2.2 & 72.0 & 22.3 & 5.7 \\
\hline 10 & BR7-4i & 1.46 & 0.45 & 0.12 & 1.63 & 14.10 & 0.0 & 0.0 & 7.4 & 2.5 & 50.9 & 37.9 & 11.2 \\
\hline
\end{tabular}


Table C-1. Measured soil properties for the Gleason Fire site, 2009-2012. MAB = months after burn, $\rho_{b}=$ bulk density, $f=$ porosity, $w=$ gravimetric soil moisture, $K_{s}=$ saturated hydraulic conductivity, $k_{a}=$ air permeability, WDPT $=$ water drop penetration time, $\mathrm{OM}=$ organic matter. A date of $-0.13 \mathrm{MAB}$ represents four days before the fire of August 13, 2009; 0.16 MAB represents five days after the fire. An entry of "n/a" means data were unavailable (continued).

\begin{tabular}{|c|c|c|c|c|c|c|c|c|c|c|c|c|c|}
\hline $\begin{array}{c}\text { Date } \\
(\mathrm{MAB})\end{array}$ & ID & $\begin{array}{c}\rho_{b} \\
\left(\mathrm{~g} \mathrm{~cm}^{-3}\right)\end{array}$ & $\begin{array}{c}f \\
\left(\mathrm{vol} \mathrm{vol}^{-1}\right)\end{array}$ & $\begin{array}{c}w \\
\left(\mathrm{~g} \mathrm{~g}^{-1}\right)\end{array}$ & $\begin{array}{c}K_{s} \\
\left(\mathrm{~cm} \mathrm{hr}^{-1}\right)\end{array}$ & $\begin{array}{c}k_{a} \\
\left(\mu \mathrm{m}^{2}\right)\end{array}$ & $\begin{array}{c}\text { WDPT } \\
{[\mathrm{s}]}\end{array}$ & $\begin{array}{c}\text { ash } \\
{[\mathrm{cm}]}\end{array}$ & $\begin{array}{c}\text { Gravel } \\
{[\%]}\end{array}$ & $\begin{array}{l}\mathrm{OM} \\
{[\%]}\end{array}$ & $\begin{array}{c}\text { Sand } \\
{[\%]}\end{array}$ & $\begin{array}{l}\text { Silt } \\
{[\%]}\end{array}$ & $\begin{array}{l}\text { Clay } \\
{[\%]}\end{array}$ \\
\hline 10 & BR7-5c & 1.26 & 0.53 & 0.10 & 3.61 & 12.01 & 3.0 & 2.0 & 11.1 & 3.2 & 62.7 & 28.4 & 8.9 \\
\hline 10 & BR7-6c & 1.25 & 0.53 & 0.11 & 3.30 & 10.90 & 0.7 & 2.0 & 10.2 & 3.2 & 67.4 & 24.8 & 7.8 \\
\hline 10 & BR7-7i & 1.51 & 0.43 & 0.09 & 1.25 & 12.81 & 0.0 & 0.0 & 7.5 & 2.0 & 62.3 & 31.4 & 6.2 \\
\hline 10 & BR7-8i & 1.41 & 0.47 & 0.11 & 2.07 & 10.27 & 0.0 & 0.0 & 10.5 & 2.4 & 53.6 & 36.5 & 9.9 \\
\hline 10 & BR8-1c & 1.13 & 0.57 & 0.04 & 0.98 & 20.60 & 1.3 & 1.5 & 8.5 & 3.3 & 56.4 & 35.1 & 8.5 \\
\hline 10 & BR8-2c & 1.30 & 0.51 & 0.18 & 2.87 & 11.93 & 0.7 & 2.0 & 6.0 & 4.0 & 55.5 & 33.9 & 10.6 \\
\hline 10 & BR8-3c & 1.10 & 0.59 & 0.23 & 2.59 & 8.78 & 1.0 & 9.0 & 1.7 & 2.9 & 59.3 & 30.3 & 10.4 \\
\hline 10 & BR8-4c & 1.10 & 0.58 & 0.06 & 1.31 & 11.84 & 1.7 & 2.0 & 23.0 & 5.1 & 68.0 & 24.6 & 7.5 \\
\hline 10 & BR8-5i & 1.43 & 0.46 & 0.16 & 1.07 & 8.96 & 1.7 & 0.0 & 5.5 & 2.8 & 59.2 & 32.3 & 8.4 \\
\hline 10 & BR8-6i & 1.50 & 0.44 & 0.14 & 1.25 & 8.77 & 0.0 & 0.0 & 8.8 & 2.6 & 51.4 & 38.0 & 10.6 \\
\hline 10 & BR8-7i & 1.45 & 0.45 & 0.14 & 1.69 & 9.13 & 0.0 & 0.0 & 9.9 & 2.9 & 53.5 & 36.6 & 9.9 \\
\hline 10 & BR8-8i & 1.53 & 0.42 & 0.16 & 0.64 & 14.88 & 0.0 & 0.0 & 7.6 & 3.1 & 44.4 & 42.7 & 12.9 \\
\hline 10 & BR9-1c & 1.22 & 0.54 & 0.07 & 0.00 & 10.53 & 802.3 & 3.0 & 19.4 & 4.2 & 65.2 & 27.5 & 7.3 \\
\hline 10 & BR9-2i & 1.55 & 0.41 & 0.19 & 3.32 & 7.96 & 2.7 & 0.0 & 9.3 & 3.2 & 60.6 & 30.8 & 8.6 \\
\hline 10 & BR9-3i & 1.55 & 0.42 & 0.19 & 3.56 & 11.28 & 1.7 & 0.0 & 9.1 & 3.3 & 60.6 & 30.6 & 8.8 \\
\hline 10 & BR9-4i & 1.75 & 0.34 & 0.17 & 2.80 & 18.42 & 2.7 & 0.0 & 9.9 & 2.3 & 54.2 & 38.4 & 7.4 \\
\hline 10 & BR9-5i & 1.61 & 0.39 & 0.18 & 0.00 & 17.40 & 1.3 & 0.0 & 4.2 & 3.3 & 63.2 & 28.7 & 8.1 \\
\hline 10 & BR9-6c & 1.20 & 0.55 & 0.03 & 2.41 & 13.68 & 480.0 & 3.0 & 12.8 & 2.7 & 67.2 & 27.0 & 5.8 \\
\hline 10 & BR9-7c & 1.55 & 0.42 & 0.22 & 1.06 & 10.80 & 612.0 & 3.0 & 3.9 & 2.9 & 65.3 & 26.7 & 8.0 \\
\hline 10 & BR9-8c & 1.18 & 0.55 & 0.06 & 0.77 & 25.83 & 371.7 & 4.0 & 3.5 & 3.9 & 56.9 & 32.9 & 10.1 \\
\hline 10 & BR10-1c & 1.02 & 0.61 & 0.22 & 5.89 & 12.75 & 22.0 & 3.0 & 7.1 & 6.1 & 56.9 & 33.1 & 10.0 \\
\hline 10 & BR10-2c & 1.31 & 0.50 & 0.04 & 3.35 & 14.55 & 480.0 & 3.0 & 11.4 & 2.8 & 61.8 & 30.3 & 8.0 \\
\hline 10 & BR10-3c & 1.23 & 0.54 & 0.06 & 2.35 & 22.30 & 308.7 & 4.0 & 11.2 & 3.2 & 59.5 & 32.2 & 8.3 \\
\hline 10 & BR10-4c & 1.52 & 0.43 & 0.25 & 3.88 & 8.81 & 2.3 & 1.0 & 5.8 & 3.9 & 54.2 & 36.6 & 9.2 \\
\hline 10 & BR10-5i & 1.66 & 0.38 & 0.13 & 1.19 & 6.33 & 1.3 & 0.0 & 17.2 & 2.0 & 68.0 & 25.9 & 6.1 \\
\hline 10 & BR10-6i & 1.47 & 0.45 & 0.08 & 0.00 & 5.30 & 1.7 & 0.0 & 7.6 & 2.7 & 50.8 & 38.9 & 10.3 \\
\hline 10 & BR10-7i & 1.62 & 0.39 & 0.14 & 1.70 & 5.21 & 0.0 & 0.0 & 20.8 & 2.5 & 60.5 & 31.2 & 8.3 \\
\hline 10 & BR10-8i & 1.45 & 0.45 & 0.15 & 1.97 & 11.30 & 1.0 & 0.0 & 6.7 & 3.1 & 56.4 & 33.2 & 10.4 \\
\hline 10 & CT5-1c & 1.70 & 0.36 & 0.13 & 2.85 & 14.15 & 2.3 & 0.0 & 25.1 & 1.7 & 79.1 & 16.9 & 4.0 \\
\hline 10 & CT5-2i & 1.72 & 0.35 & 0.18 & 1.11 & 11.70 & 1.7 & 0.0 & 10.9 & 2.3 & 60.7 & 31.5 & 7.8 \\
\hline 10 & СТ5-3c & 1.69 & 0.36 & 0.22 & 5.00 & 12.39 & 1.7 & 0.0 & 8.8 & 2.5 & 70.1 & 23.7 & 6.2 \\
\hline
\end{tabular}


Table C-1. Measured soil properties for the Gleason Fire site, 2009-2012. MAB = months after burn, $\rho_{b}=$ bulk density, $f=$ porosity, $w=$ gravimetric soil moisture, $K_{s}=$ saturated hydraulic conductivity, $k_{a}=$ air permeability, WDPT = water drop penetration time, $\mathrm{OM}=$ organic matter. A date of $-0.13 \mathrm{MAB}$ represents four days before the fire of August 13, 2009; 0.16 MAB represents five days after the fire. An entry of " $\mathrm{n} / \mathrm{a}$ " means data were unavailable (continued).

\begin{tabular}{|c|c|c|c|c|c|c|c|c|c|c|c|c|c|}
\hline $\begin{array}{c}\text { Date } \\
(\mathrm{MAB})\end{array}$ & ID & $\begin{array}{c}\rho_{b} \\
\left(\mathrm{~g} \mathrm{~cm}^{-3}\right)\end{array}$ & $\begin{array}{c}f \\
\left(\mathrm{vol} \mathrm{vol}^{-1}\right)\end{array}$ & $\begin{array}{c}w \\
\left(\mathrm{~g} \mathrm{~g}^{-1}\right)\end{array}$ & $\begin{array}{c}K_{s} \\
\left(\mathrm{~cm} \mathrm{hr}^{-1}\right)\end{array}$ & $\begin{array}{c}k_{a} \\
\left(\mu \mathrm{m}^{2}\right)\end{array}$ & $\begin{array}{c}\text { WDPT } \\
{[\mathrm{s}]}\end{array}$ & $\begin{array}{c}\text { ash } \\
{[\mathrm{cm}]}\end{array}$ & $\begin{array}{c}\text { Gravel } \\
{[\%]}\end{array}$ & $\begin{array}{l}\mathrm{OM} \\
{[\%]}\end{array}$ & $\begin{array}{c}\text { Sand } \\
{[\%]}\end{array}$ & $\begin{array}{l}\text { Silt } \\
{[\%]}\end{array}$ & $\begin{array}{l}\text { Clay } \\
{[\%]}\end{array}$ \\
\hline 10 & CT5-4c & 1.57 & 0.41 & 0.19 & 3.13 & 12.10 & 1.7 & 0.0 & 4.3 & 2.4 & 75.8 & 19.3 & 4.9 \\
\hline 10 & CT5-5i & 1.64 & 0.38 & 0.20 & 1.02 & 11.16 & 2.0 & 0.0 & 7.4 & 3.0 & 64.1 & 28.0 & 7.9 \\
\hline 10 & CT5-6c & 1.81 & 0.32 & 0.19 & 3.16 & 29.49 & 3.0 & 0.0 & 7.6 & 2.1 & 71.4 & 22.7 & 5.9 \\
\hline 10 & СТ5-7i & 1.72 & 0.35 & 0.17 & 1.87 & 11.19 & 1.7 & 0.0 & 3.4 & 2.1 & 57.0 & 35.0 & 8.0 \\
\hline 10 & СТ5-8i & 1.68 & 0.37 & 0.16 & 1.22 & 4.46 & 1.7 & 0.0 & 7.4 & 2.8 & 52.4 & 36.5 & 11.1 \\
\hline 10 & CT6-1c & 1.74 & 0.34 & 0.16 & 3.61 & 9.36 & 12.7 & 0.0 & 13.2 & 1.3 & 80.2 & 16.6 & 3.2 \\
\hline 10 & СT6-2c & 1.56 & 0.41 & 0.10 & 2.96 & 11.18 & 5.3 & 0.0 & 18.6 & 1.4 & 87.1 & 9.9 & 3.0 \\
\hline 10 & СТ6-3i & 1.46 & 0.45 & 0.06 & 0.01 & 7.95 & 3.0 & 0.0 & 14.9 & 1.2 & 80.6 & 15.3 & 4.1 \\
\hline 10 & CT6-4i & 1.75 & 0.34 & 0.18 & 3.19 & 11.15 & 2.0 & 0.0 & 10.4 & 2.1 & 51.9 & 37.5 & 10.6 \\
\hline 10 & СТ6-5i & 1.70 & 0.36 & 0.18 & 1.43 & 18.11 & 2.3 & 0.0 & 2.9 & 2.0 & 61.9 & 29.7 & 8.4 \\
\hline 10 & СТ6-6c & 1.53 & 0.42 & 0.16 & 4.09 & 27.16 & 3.7 & 0.0 & 7.2 & 1.9 & 74.5 & 20.8 & 4.7 \\
\hline 10 & СТ6-7i & 1.66 & 0.38 & 0.15 & 4.46 & 10.42 & 0.7 & 0.0 & 9.8 & 1.9 & 65.4 & 27.6 & 7.0 \\
\hline 10 & СТ6-8c & 1.44 & 0.46 & 0.14 & 2.98 & 15.49 & 2.0 & 0.0 & 12.8 & 2.4 & 74.7 & 20.4 & 4.9 \\
\hline 12 & BR11-1c & 1.32 & 0.50 & 0.11 & 1.39 & 3.42 & 12.7 & 2.0 & 12.0 & 2.7 & 48.4 & 41.4 & 10.2 \\
\hline 12 & BR11-2c & 1.44 & 0.46 & 0.07 & 1.33 & 3.18 & 1.3 & 0.0 & 12.3 & 2.0 & 48.9 & 37.4 & 13.7 \\
\hline 12 & BR11-3i & 1.49 & 0.44 & 0.11 & 0.49 & 7.52 & 4.7 & 2.0 & 16.7 & 2.2 & 54.1 & 35.4 & 10.5 \\
\hline 12 & BR11-4i & 1.39 & 0.47 & 0.09 & 3.24 & 7.72 & 2.3 & 0.0 & 10.7 & 2.3 & 55.4 & 32.7 & 11.9 \\
\hline 12 & BR11-5i & 1.39 & 0.47 & 0.08 & 0.22 & 5.88 & 11.7 & 4.0 & 20.0 & 2.1 & 57.8 & 32.9 & 9.3 \\
\hline 12 & BR11-6i & 1.50 & 0.43 & 0.11 & 1.43 & 7.72 & 2.0 & 0.0 & 10.2 & 2.1 & 43.1 & 41.0 & 15.9 \\
\hline 12 & BR11-7c & 1.42 & 0.46 & 0.08 & 1.35 & 25.05 & 2.0 & 0.0 & 25.3 & 1.4 & 46.4 & 41.2 & 12.3 \\
\hline 12 & BR11-8c & 1.23 & 0.54 & 0.09 & 3.51 & 5.00 & 2.3 & 0.0 & 7.7 & 2.5 & 59.3 & 30.5 & 10.2 \\
\hline 12 & BR12-1c & 1.34 & 0.50 & 0.16 & 3.46 & 8.78 & 5.0 & 1.0 & 9.7 & 2.3 & 62.2 & 28.6 & 9.2 \\
\hline 12 & BR12-2c & 1.46 & 0.45 & 0.15 & 3.11 & 6.29 & 10.0 & 1.0 & 26.1 & 2.2 & 59.6 & 33.2 & 7.2 \\
\hline 12 & BR12-3i & 1.29 & 0.51 & 0.13 & 5.64 & 7.91 & 371.0 & 0.0 & 14.7 & 3.1 & 62.3 & 28.3 & 9.4 \\
\hline 12 & BR12-4i & 1.57 & 0.41 & 0.10 & 5.59 & 4.12 & 16.0 & 1.0 & 26.0 & 1.8 & 74.5 & 19.7 & 5.8 \\
\hline 12 & BR12-5c & 1.47 & 0.44 & 0.10 & 0.64 & 22.13 & 2.0 & 0.0 & 15.3 & 1.7 & 55.3 & 34.7 & 10.0 \\
\hline 12 & BR12-6c & 1.54 & 0.42 & 0.11 & 1.53 & 3.98 & 1.3 & 0.0 & 22.8 & 1.5 & 55.4 & 35.3 & 9.3 \\
\hline 12 & BR12-7i & 1.53 & 0.42 & 0.13 & 1.05 & 12.43 & 1.3 & 0.0 & 11.0 & 1.6 & 50.6 & 36.8 & 12.6 \\
\hline 12 & BR12-8i & 1.46 & 0.45 & 0.12 & 2.28 & 8.48 & 1.3 & 0.0 & 11.0 & 1.5 & 50.2 & 39.3 & 10.5 \\
\hline 12 & BR13-1c & 1.39 & 0.48 & 0.12 & 1.59 & 5.68 & 1.3 & 0.0 & 15.7 & 2.7 & 50.9 & 35.2 & 13.9 \\
\hline 12 & BR13-2c & 1.33 & 0.50 & 0.19 & 2.69 & 7.93 & 3.7 & 1.0 & 8.1 & 3.4 & 52.9 & 35.6 & 11.5 \\
\hline
\end{tabular}


Table C-1. Measured soil properties for the Gleason Fire site, 2009-2012. MAB = months after burn, $\rho_{b}=$ bulk density, $f=$ porosity,

$w=$ gravimetric soil moisture, $K_{s}=$ saturated hydraulic conductivity, $k_{a}=$ air permeability, WDPT = water drop penetration time,

$\mathrm{OM}=$ organic matter. A date of $-0.13 \mathrm{MAB}$ represents four days before the fire of August 13, 2009; 0.16 MAB represents five days after the fire. An entry of " $\mathrm{n} / \mathrm{a}$ " means data were unavailable (continued).

\begin{tabular}{|c|c|c|c|c|c|c|c|c|c|c|c|c|c|}
\hline $\begin{array}{c}\text { Date } \\
(\mathrm{MAB})\end{array}$ & ID & $\begin{array}{c}\rho_{b} \\
\left(\mathrm{~g} \mathrm{~cm}^{-3}\right)\end{array}$ & $\begin{array}{c}f \\
\left(\mathrm{vol} \mathrm{vol}^{-1}\right)\end{array}$ & $\begin{array}{c}w \\
\left(\mathrm{~g} \mathrm{~g}^{-1}\right)\end{array}$ & $\begin{array}{c}K_{s} \\
\left(\mathrm{~cm} \mathrm{hr}^{-1}\right)\end{array}$ & $\begin{array}{c}k_{a} \\
\left(\mu \mathrm{m}^{2}\right)\end{array}$ & $\begin{array}{c}\text { WDPT } \\
{[\mathrm{s}]}\end{array}$ & $\begin{array}{c}\text { ash } \\
{[\mathrm{cm}]}\end{array}$ & $\begin{array}{c}\text { Gravel } \\
{[\%]}\end{array}$ & $\begin{array}{l}\mathrm{OM} \\
{[\%]}\end{array}$ & $\begin{array}{c}\text { Sand } \\
{[\%]}\end{array}$ & $\begin{array}{l}\text { Silt } \\
{[\%]}\end{array}$ & $\begin{array}{l}\text { Clay } \\
{[\%]}\end{array}$ \\
\hline 12 & BR13-3c & 1.26 & 0.52 & 0.14 & 3.75 & 9.23 & 4.0 & 2.0 & 11.0 & 3.2 & 53.4 & 37.1 & 9.4 \\
\hline 12 & BR13-4c & 1.40 & 0.47 & 0.15 & 4.76 & 218.92 & 522.7 & 10.0 & 25.2 & 2.8 & 63.5 & 28.5 & 7.9 \\
\hline 12 & BR13-5i & 1.39 & 0.48 & 0.13 & 2.13 & 12.34 & 1.0 & 0.0 & 9.6 & 2.5 & 58.2 & 30.6 & 11.3 \\
\hline 12 & BR13-6i & 1.67 & 0.37 & 0.16 & 1.13 & 11.93 & 2.0 & 0.0 & 28.3 & 2.4 & 60.9 & 29.5 & 9.5 \\
\hline 12 & BR13-7i & 1.66 & 0.37 & 0.14 & 0.31 & 9.81 & 2.3 & 0.0 & 25.6 & 1.8 & 55.5 & 35.0 & 9.6 \\
\hline 12 & BR13-8i & 1.37 & 0.48 & 0.16 & 2.36 & 8.93 & 30.7 & 1.0 & 18.8 & 2.5 & 64.8 & 26.3 & 8.9 \\
\hline 12 & BR14-1c & 1.51 & 0.43 & 0.12 & 2.10 & 17.85 & 6.3 & 0.0 & 22.7 & 2.2 & 48.6 & 38.8 & 12.5 \\
\hline 12 & BR14-2i & 1.37 & 0.48 & 0.14 & 3.61 & 12.26 & 51.0 & 20.0 & 13.9 & 2.1 & 53.5 & 35.4 & 11.1 \\
\hline 12 & BR14-3i & 1.38 & 0.48 & 0.13 & 3.29 & 14.31 & 59.7 & 3.0 & 19.1 & 2.2 & 53.6 & 35.5 & 10.9 \\
\hline 12 & BR14-4i & 1.78 & 0.33 & 0.14 & 2.28 & 12.73 & 2.3 & 0.0 & 27.7 & 1.4 & 56.6 & 35.4 & 8.1 \\
\hline 12 & BR14-5i & 1.30 & 0.51 & 0.16 & 2.46 & 9.95 & 157.0 & 10.0 & 23.2 & 3.6 & 58.2 & 33.0 & 8.8 \\
\hline 12 & BR14-6c & 1.50 & 0.43 & 0.14 & 2.79 & 11.85 & 5.0 & 0.0 & 20.6 & 2.1 & 53.8 & 35.3 & 10.9 \\
\hline 12 & BR14-7c & 1.40 & 0.47 & 0.17 & 0.15 & 11.84 & 3.7 & 0.0 & 10.1 & 2.7 & 54.5 & 34.9 & 10.6 \\
\hline 12 & BR14-8c & 1.28 & 0.52 & 0.14 & 1.83 & 8.32 & 3.0 & 0.0 & 10.3 & 3.6 & 50.9 & 38.0 & 11.1 \\
\hline 12 & BR15-1c & 1.44 & 0.45 & 0.18 & 0.86 & 13.11 & 4.0 & 0.0 & 12.8 & 2.1 & 54.8 & 33.3 & 11.9 \\
\hline 12 & BR15-2c & 1.06 & 0.60 & 0.12 & 1.02 & 7.57 & 5.0 & 45.0 & 7.3 & 3.4 & 44.2 & 41.9 & 13.9 \\
\hline 12 & BR15-3c & 1.10 & 0.58 & 0.12 & 3.61 & 15.21 & 18.7 & 16.0 & 15.5 & 5.3 & 47.8 & 39.6 & 12.6 \\
\hline 12 & BR15-4c & 1.51 & 0.43 & 0.16 & 1.47 & 13.76 & 4.7 & 1.0 & 22.0 & 2.8 & 46.8 & 42.0 & 11.2 \\
\hline 12 & BR15-5i & 1.53 & 0.42 & 0.18 & 0.02 & 9.55 & 1.3 & 0.0 & 11.6 & 2.6 & 53.7 & 34.4 & 11.9 \\
\hline 12 & BR15-6i & 1.84 & 0.31 & 0.15 & 1.45 & 10.47 & 2.3 & 0.0 & 14.7 & 1.9 & 48.5 & 42.6 & 8.9 \\
\hline 12 & BR15-7i & 1.63 & 0.38 & 0.15 & 1.23 & 29.34 & 1.3 & 0.0 & 30.9 & 2.1 & 57.3 & 32.1 & 10.6 \\
\hline 12 & BR15-8i & 1.39 & 0.47 & 0.20 & 1.73 & 10.18 & 4.0 & 1.0 & 13.6 & 3.0 & 55.4 & 34.6 & 10.0 \\
\hline 12 & CT7-1c & 1.46 & 0.45 & 0.13 & 3.99 & 21.87 & 2.3 & 0.0 & 21.4 & 2.0 & 61.3 & 30.3 & 8.4 \\
\hline 12 & CT7-2i & 1.54 & 0.42 & 0.13 & 1.91 & 6.91 & 3.3 & 0.0 & 20.1 & 1.6 & 54.9 & 36.6 & 8.5 \\
\hline 12 & CT7-3c & 1.36 & 0.49 & 0.13 & 2.82 & 10.96 & 4.3 & 0.0 & 13.4 & 2.1 & 66.2 & 25.2 & 8.6 \\
\hline 12 & CT7-4c & 1.67 & 0.37 & 0.14 & 1.66 & 14.05 & 3.3 & 0.0 & 27.9 & 1.6 & 61.8 & 30.2 & 8.0 \\
\hline 12 & CT7-5i & 1.60 & 0.40 & 0.15 & 2.73 & 12.49 & 2.7 & 0.0 & 17.1 & 1.8 & 59.7 & 31.9 & 8.4 \\
\hline 12 & CT7-6c & 1.51 & 0.43 & 0.10 & 1.91 & 9.80 & 3.0 & 0.0 & 24.4 & 1.8 & 63.0 & 29.1 & 7.9 \\
\hline 12 & CT7-7i & 1.41 & 0.47 & 0.12 & 1.09 & 10.52 & 1.7 & 0.0 & 9.4 & 2.2 & 52.0 & 37.5 & 10.5 \\
\hline 12 & CT7-8i & 1.27 & 0.52 & 0.14 & 3.46 & 24.65 & 29.0 & 0.0 & 6.2 & 2.7 & 58.2 & 31.5 & 10.3 \\
\hline 12 & СТ8-1c & 1.54 & 0.42 & 0.08 & 5.41 & 27.03 & 3.7 & 0.0 & 49.1 & 2.2 & 62.4 & 29.9 & 7.7 \\
\hline
\end{tabular}


Table C-1. Measured soil properties for the Gleason Fire site, 2009-2012. MAB = months after burn, $\rho_{b}=$ bulk density, $f=$ porosity, $w=$ gravimetric soil moisture, $K_{s}=$ saturated hydraulic conductivity, $k_{a}=$ air permeability, WDPT = water drop penetration time, $\mathrm{OM}=$ organic matter. A date of $-0.13 \mathrm{MAB}$ represents four days before the fire of August 13, 2009; 0.16 MAB represents five days after the fire. An entry of "n/a" means data were unavailable (continued).

\begin{tabular}{|c|c|c|c|c|c|c|c|c|c|c|c|c|c|}
\hline $\begin{array}{c}\text { Date } \\
\text { (MAB) }\end{array}$ & ID & $\begin{array}{c}\rho_{b} \\
\left(\mathrm{~g} \mathrm{~cm}^{-3}\right)\end{array}$ & 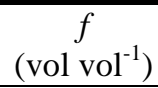 & $\begin{array}{c}w \\
\left(\mathrm{~g} \mathrm{~g}^{-1}\right)\end{array}$ & $\begin{array}{c}K_{s} \\
\left(\mathrm{~cm} \mathrm{hr}^{-1}\right)\end{array}$ & $\begin{array}{c}k_{a} \\
\left(\mu \mathrm{m}^{2}\right)\end{array}$ & $\begin{array}{c}\text { WDPT } \\
{[\mathrm{s}]}\end{array}$ & $\begin{array}{c}\text { ash } \\
{[\mathrm{cm}]}\end{array}$ & $\begin{array}{c}\text { Gravel } \\
{[\%]}\end{array}$ & $\begin{array}{l}\mathrm{OM} \\
{[\%]}\end{array}$ & $\begin{array}{c}\text { Sand } \\
{[\%]}\end{array}$ & $\begin{array}{l}\text { Silt } \\
{[\%]}\end{array}$ & $\begin{array}{l}\text { Clay } \\
{[\%]}\end{array}$ \\
\hline 12 & CT8-2c & 1.55 & 0.42 & 0.14 & 0.90 & 34.31 & 3.7 & 0.0 & 13.2 & 1.8 & 45.8 & 45.4 & 8.8 \\
\hline 12 & СТ8-3i & 1.40 & 0.47 & 0.14 & 3.62 & 26.65 & 3.3 & 0.0 & 12.9 & 2.2 & 55.0 & 34.2 & 10.8 \\
\hline 12 & СТ8-4i & 1.52 & 0.43 & 0.13 & 1.22 & 19.44 & 2.0 & 0.0 & 11.5 & 2.1 & 47.3 & 40.6 & 12.0 \\
\hline 12 & СТ8-5i & 1.46 & 0.45 & 0.12 & 2.13 & 19.85 & 3.0 & 0.0 & 22.4 & 2.3 & 54.7 & 34.5 & 10.8 \\
\hline 12 & CT8-6c & 1.51 & 0.43 & 0.14 & 2.54 & 13.84 & 2.3 & 0.0 & 24.5 & 2.6 & 57.3 & 32.7 & 10.0 \\
\hline 12 & СТ8-7i & 1.65 & 0.38 & 0.15 & 2.97 & 16.46 & 3.7 & 0.0 & 14.9 & 2.2 & 57.4 & 32.9 & 9.7 \\
\hline 12 & СТ8-8c & 1.47 & 0.45 & 0.16 & 1.05 & 19.96 & 2.0 & 0.0 & 12.5 & 2.6 & 54.6 & 34.5 & 11.0 \\
\hline 22 & BR16-1c & 1.32 & 0.50 & 0.27 & 6.63 & 9.56 & $\mathrm{n} / \mathrm{a}$ & $\mathrm{n} / \mathrm{a}$ & 13.1 & 3.3 & 59.4 & 30.7 & 9.9 \\
\hline 22 & BR16-2c & 1.31 & 0.50 & 0.29 & 4.90 & 11.61 & $\mathrm{n} / \mathrm{a}$ & $\mathrm{n} / \mathrm{a}$ & 13.8 & 3.2 & 57.6 & 32.0 & 10.4 \\
\hline 22 & BR16-3i & 1.53 & 0.42 & 0.29 & 3.99 & 9.52 & $\mathrm{n} / \mathrm{a}$ & $\mathrm{n} / \mathrm{a}$ & 13.0 & 2.8 & 62.3 & 29.1 & 8.6 \\
\hline 22 & BR16-4c & 1.55 & 0.41 & 0.33 & 5.58 & 3.56 & $\mathrm{n} / \mathrm{a}$ & $\mathrm{n} / \mathrm{a}$ & 16.1 & 3.3 & 64.8 & 27.5 & 7.7 \\
\hline 22 & BR16-5i & 1.40 & 0.47 & 0.37 & 6.54 & 4.38 & $\mathrm{n} / \mathrm{a}$ & $\mathrm{n} / \mathrm{a}$ & 15.8 & 3.9 & 64.4 & 27.5 & 8.0 \\
\hline 22 & BR16-6i & 1.69 & 0.36 & 0.37 & 4.18 & 5.51 & $\mathrm{n} / \mathrm{a}$ & $\mathrm{n} / \mathrm{a}$ & 11.4 & 2.6 & 58.5 & 30.7 & 10.8 \\
\hline 22 & BR16-7i & 1.59 & 0.40 & 0.26 & 3.77 & 22.38 & $\mathrm{n} / \mathrm{a}$ & $\mathrm{n} / \mathrm{a}$ & 21.2 & 2.3 & 59.0 & 31.2 & 9.8 \\
\hline 22 & BR16-8c & 1.33 & 0.50 & 0.21 & 7.52 & 13.63 & $\mathrm{n} / \mathrm{a}$ & $\mathrm{n} / \mathrm{a}$ & 21.8 & 2.3 & 76.6 & 18.4 & 5.0 \\
\hline 22 & BR17B-1c & 1.34 & 0.50 & 0.41 & 5.60 & 11.55 & $\mathrm{n} / \mathrm{a}$ & $\mathrm{n} / \mathrm{a}$ & 10.1 & 4.1 & 46.0 & 40.5 & 13.6 \\
\hline 22 & BR17B-2c & 1.19 & 0.55 & 0.39 & 2.32 & 11.56 & $\mathrm{n} / \mathrm{a}$ & $\mathrm{n} / \mathrm{a}$ & 12.4 & 4.0 & 53.9 & 36.1 & 9.9 \\
\hline 22 & BR17B-3i & 1.50 & 0.44 & 0.37 & 1.33 & 17.51 & $\mathrm{n} / \mathrm{a}$ & $\mathrm{n} / \mathrm{a}$ & 12.3 & 3.4 & 45.2 & 41.5 & 13.3 \\
\hline 22 & BR17B-4i & 1.64 & 0.38 & 0.34 & 5.12 & 17.51 & $\mathrm{n} / \mathrm{a}$ & $\mathrm{n} / \mathrm{a}$ & 11.1 & 3.6 & 39.5 & 45.1 & 15.4 \\
\hline 22 & BR17B-5c & 1.51 & 0.43 & 0.36 & 2.27 & 18.45 & $\mathrm{n} / \mathrm{a}$ & $\mathrm{n} / \mathrm{a}$ & 9.3 & 4.0 & 46.4 & 41.4 & 12.2 \\
\hline 22 & BR17B-6i & 1.45 & 0.45 & 0.44 & 4.94 & 18.65 & $\mathrm{n} / \mathrm{a}$ & $\mathrm{n} / \mathrm{a}$ & 5.2 & 4.0 & 50.1 & 38.1 & 11.9 \\
\hline 22 & BR17B-7i & 1.44 & 0.46 & 0.39 & 3.34 & 14.88 & $\mathrm{n} / \mathrm{a}$ & $\mathrm{n} / \mathrm{a}$ & 6.7 & 3.7 & 47.2 & 39.7 & 13.1 \\
\hline 22 & BR17B-8c & 1.59 & 0.40 & 0.32 & 4.26 & 20.78 & $\mathrm{n} / \mathrm{a}$ & $\mathrm{n} / \mathrm{a}$ & 8.7 & 3.6 & 38.2 & 46.0 & 15.8 \\
\hline 22 & BR18B-1c & 1.44 & 0.46 & 0.42 & 5.68 & 9.67 & $\mathrm{n} / \mathrm{a}$ & $\mathrm{n} / \mathrm{a}$ & 8.1 & 4.1 & 51.9 & 37.2 & 10.8 \\
\hline 22 & BR18B-2c & 1.29 & 0.51 & 0.37 & 5.86 & 15.07 & $\mathrm{n} / \mathrm{a}$ & $\mathrm{n} / \mathrm{a}$ & 9.6 & 3.9 & 51.2 & 37.5 & 11.3 \\
\hline 22 & BR18B-3i & 1.50 & 0.43 & 0.30 & 5.28 & 8.29 & $\mathrm{n} / \mathrm{a}$ & $\mathrm{n} / \mathrm{a}$ & 19.5 & 3.5 & 42.9 & 44.1 & 13.1 \\
\hline 22 & BR18B-4i & 1.56 & 0.41 & 0.43 & 4.42 & 5.29 & $\mathrm{n} / \mathrm{a}$ & $\mathrm{n} / \mathrm{a}$ & 7.4 & 3.7 & 46.2 & 39.4 & 14.3 \\
\hline 22 & BR18B-5c & 1.56 & 0.41 & 0.40 & 7.95 & 19.38 & $\mathrm{n} / \mathrm{a}$ & $\mathrm{n} / \mathrm{a}$ & 10.3 & 3.2 & 44.1 & 43.0 & 12.9 \\
\hline 22 & BR18B-6i & 1.60 & 0.40 & 0.32 & 3.84 & 4.99 & $\mathrm{n} / \mathrm{a}$ & $\mathrm{n} / \mathrm{a}$ & 8.0 & 2.4 & 34.2 & 52.1 & 13.6 \\
\hline 22 & BR18B-7i & 1.64 & 0.38 & 0.32 & 2.78 & 47.40 & $\mathrm{n} / \mathrm{a}$ & $\mathrm{n} / \mathrm{a}$ & 8.5 & 2.7 & 31.2 & 51.9 & 16.9 \\
\hline 22 & BR18B-8c & 1.55 & 0.41 & 0.26 & 4.29 & 21.28 & $\mathrm{n} / \mathrm{a}$ & $\mathrm{n} / \mathrm{a}$ & 29.5 & 2.4 & 57.1 & 34.7 & 8.1 \\
\hline
\end{tabular}


Table C-1. Measured soil properties for the Gleason Fire site, 2009-2012. MAB = months after burn, $\rho_{b}=$ bulk density, $f=$ porosity, $w=$ gravimetric soil moisture, $K_{s}=$ saturated hydraulic conductivity, $k_{a}=$ air permeability, WDPT = water drop penetration time, $\mathrm{OM}=$ organic matter. A date of $-0.13 \mathrm{MAB}$ represents four days before the fire of August 13, 2009; 0.16 MAB represents five days after the fire. An entry of "n/a" means data were unavailable (continued).

\begin{tabular}{|c|c|c|c|c|c|c|c|c|c|c|c|c|c|}
\hline $\begin{array}{c}\text { Date } \\
(\mathrm{MAB})\end{array}$ & ID & $\begin{array}{c}\rho_{b} \\
\left(\mathrm{~g} \mathrm{~cm}^{-3}\right)\end{array}$ & $\begin{array}{c}f \\
\left(\mathrm{vol} \mathrm{vol}^{-1}\right)\end{array}$ & $\begin{array}{c}w \\
\left(\mathrm{~g} \mathrm{~g}^{-1}\right)\end{array}$ & $\begin{array}{c}K_{s} \\
\left(\mathrm{~cm} \mathrm{hr}^{-1}\right)\end{array}$ & $\begin{array}{c}k_{a} \\
\left(\mu \mathrm{m}^{2}\right)\end{array}$ & $\begin{array}{c}\text { WDPT } \\
{[\mathrm{s}]}\end{array}$ & $\begin{array}{c}\text { ash } \\
{[\mathrm{cm}]}\end{array}$ & $\begin{array}{c}\text { Gravel } \\
{[\%]}\end{array}$ & $\begin{array}{l}\mathrm{OM} \\
{[\%]}\end{array}$ & $\begin{array}{c}\text { Sand } \\
{[\%]}\end{array}$ & $\begin{array}{l}\text { Silt } \\
{[\%]}\end{array}$ & $\begin{array}{l}\text { Clay } \\
{[\%]}\end{array}$ \\
\hline 22 & BR19-1c & 1.04 & 0.61 & 0.44 & 2.16 & 9.26 & $\mathrm{n} / \mathrm{a}$ & $\mathrm{n} / \mathrm{a}$ & 7.1 & 3.1 & 55.2 & 36.9 & 7.9 \\
\hline 22 & BR19-2c & 1.37 & 0.48 & 0.37 & 4.24 & 9.72 & $\mathrm{n} / \mathrm{a}$ & $\mathrm{n} / \mathrm{a}$ & 9.7 & 4.0 & 51.7 & 37.7 & 10.6 \\
\hline 22 & BR19-3i & 1.70 & 0.36 & 0.35 & 2.94 & 5.41 & $\mathrm{n} / \mathrm{a}$ & $\mathrm{n} / \mathrm{a}$ & 11.9 & 2.9 & 46.9 & 41.2 & 11.9 \\
\hline 22 & BR19-4i & 1.65 & 0.38 & 0.33 & 4.21 & 11.03 & $\mathrm{n} / \mathrm{a}$ & $\mathrm{n} / \mathrm{a}$ & 22.9 & 2.9 & 46.7 & 41.1 & 12.2 \\
\hline 22 & BR19-5c & 1.42 & 0.47 & 0.37 & 3.77 & 10.89 & $\mathrm{n} / \mathrm{a}$ & $\mathrm{n} / \mathrm{a}$ & 20.5 & 3.4 & 54.5 & 36.6 & 8.9 \\
\hline 22 & BR19-6c & 1.17 & 0.56 & 0.42 & 5.56 & 10.21 & $\mathrm{n} / \mathrm{a}$ & $\mathrm{n} / \mathrm{a}$ & 8.8 & 4.1 & 50.4 & 39.1 & 10.5 \\
\hline 22 & BR19-7i & 1.30 & 0.51 & 0.36 & 4.25 & 7.60 & $\mathrm{n} / \mathrm{a}$ & $\mathrm{n} / \mathrm{a}$ & 10.7 & 3.3 & 46.9 & 41.8 & 11.3 \\
\hline 22 & BR19-8i & 1.39 & 0.47 & 0.35 & 4.37 & 5.50 & $\mathrm{n} / \mathrm{a}$ & $\mathrm{n} / \mathrm{a}$ & 4.8 & 3.6 & 58.5 & 39.3 & 2.2 \\
\hline 22 & BR20-1c & 1.66 & 0.37 & 0.37 & 2.16 & 8.07 & $\mathrm{n} / \mathrm{a}$ & $\mathrm{n} / \mathrm{a}$ & 34.0 & 4.4 & 45.7 & 40.8 & 13.6 \\
\hline 22 & BR20-2c & 1.48 & 0.44 & 0.42 & 5.24 & 24.17 & $\mathrm{n} / \mathrm{a}$ & $\mathrm{n} / \mathrm{a}$ & 12.0 & 3.7 & 48.9 & 38.6 & 12.5 \\
\hline 22 & BR20-3i & 1.57 & 0.41 & 0.33 & 1.83 & 5.75 & $\mathrm{n} / \mathrm{a}$ & $\mathrm{n} / \mathrm{a}$ & 11.7 & 3.0 & 51.5 & 37.2 & 11.3 \\
\hline 22 & BR20-4i & 1.56 & 0.41 & 0.30 & 2.54 & 4.14 & $\mathrm{n} / \mathrm{a}$ & $\mathrm{n} / \mathrm{a}$ & 9.0 & 2.8 & 45.0 & 42.0 & 13.0 \\
\hline 22 & BR20-5i & 1.50 & 0.43 & 0.30 & 8.57 & 5.30 & $\mathrm{n} / \mathrm{a}$ & $\mathrm{n} / \mathrm{a}$ & 13.0 & 2.9 & 50.1 & 38.1 & 11.8 \\
\hline 22 & BR20-6c & 1.77 & 0.33 & 0.32 & 3.78 & 4.96 & $\mathrm{n} / \mathrm{a}$ & $\mathrm{n} / \mathrm{a}$ & 22.2 & 2.9 & 50.8 & 38.5 & 10.7 \\
\hline 22 & BR20-7i & 1.90 & 0.28 & 0.29 & 5.81 & 5.00 & $\mathrm{n} / \mathrm{a}$ & $\mathrm{n} / \mathrm{a}$ & 30.8 & 3.5 & 47.6 & 40.3 & 12.1 \\
\hline 22 & BR20-8c & 1.54 & 0.42 & 0.30 & 4.05 & 36.76 & $\mathrm{n} / \mathrm{a}$ & $\mathrm{n} / \mathrm{a}$ & 12.3 & 3.1 & 53.6 & 34.6 & 11.8 \\
\hline 22 & СТ9-1c & 1.17 & 0.56 & 0.33 & 2.34 & 9.40 & $\mathrm{n} / \mathrm{a}$ & $\mathrm{n} / \mathrm{a}$ & 27.1 & 5.5 & 53.4 & 36.8 & 9.8 \\
\hline 22 & СТ9-2c & 1.40 & 0.47 & 0.30 & 4.67 & 6.55 & $\mathrm{n} / \mathrm{a}$ & $\mathrm{n} / \mathrm{a}$ & 34.7 & 4.0 & 54.3 & 35.8 & 9.9 \\
\hline 22 & СТ9-3c & 1.50 & 0.43 & 0.32 & 0.95 & 14.59 & $\mathrm{n} / \mathrm{a}$ & $\mathrm{n} / \mathrm{a}$ & 20.7 & 3.0 & 53.5 & 37.6 & 8.9 \\
\hline 22 & СТ9-4i & 1.34 & 0.50 & 0.28 & 0.00 & 5.44 & $\mathrm{n} / \mathrm{a}$ & $\mathrm{n} / \mathrm{a}$ & 10.1 & 3.2 & 43.0 & 45.2 & 11.7 \\
\hline 22 & СТ9-5c & 1.43 & 0.46 & 0.33 & 5.48 & 17.71 & $\mathrm{n} / \mathrm{a}$ & $\mathrm{n} / \mathrm{a}$ & 4.3 & 3.9 & 41.9 & 44.6 & 13.4 \\
\hline 22 & СТ9-6i & 1.72 & 0.35 & 0.28 & 0.38 & 13.60 & $\mathrm{n} / \mathrm{a}$ & $\mathrm{n} / \mathrm{a}$ & 26.9 & 3.3 & 48.2 & 41.3 & 10.5 \\
\hline 22 & СТ9-7i & 1.83 & 0.31 & 0.27 & 2.06 & 16.17 & $\mathrm{n} / \mathrm{a}$ & $\mathrm{n} / \mathrm{a}$ & 31.9 & 2.7 & 55.7 & 36.1 & 8.2 \\
\hline 22 & СТ9-8i & 1.47 & 0.45 & 0.28 & 1.17 & 21.41 & $\mathrm{n} / \mathrm{a}$ & $\mathrm{n} / \mathrm{a}$ & 12.2 & 3.3 & 53.5 & 36.1 & 10.5 \\
\hline 22 & CT10-1i & 1.54 & 0.42 & 0.29 & 0.01 & 9.11 & $\mathrm{n} / \mathrm{a}$ & $\mathrm{n} / \mathrm{a}$ & 17.5 & 2.4 & 53.8 & 36.7 & 9.5 \\
\hline 22 & CT10-2i & 1.77 & 0.33 & 0.29 & 1.21 & 7.53 & $\mathrm{n} / \mathrm{a}$ & $\mathrm{n} / \mathrm{a}$ & 30.7 & 2.7 & 52.0 & 38.3 & 9.8 \\
\hline 22 & CT10-3c & 0.94 & 0.64 & 0.20 & 3.70 & 15.01 & $\mathrm{n} / \mathrm{a}$ & $\mathrm{n} / \mathrm{a}$ & 24.3 & 3.3 & 62.3 & 31.2 & 6.5 \\
\hline 22 & CT10-4c & 1.20 & 0.55 & 0.26 & 2.80 & 15.37 & $\mathrm{n} / \mathrm{a}$ & $\mathrm{n} / \mathrm{a}$ & 10.1 & 3.4 & 59.7 & 31.8 & 8.5 \\
\hline 22 & CT10-5i & 1.61 & 0.39 & 0.26 & 1.17 & 13.82 & $\mathrm{n} / \mathrm{a}$ & $\mathrm{n} / \mathrm{a}$ & 37.1 & 2.2 & 55.6 & 37.0 & 7.5 \\
\hline 22 & CT10-6c & 1.54 & 0.42 & 0.28 & 2.51 & 11.85 & $\mathrm{n} / \mathrm{a}$ & $\mathrm{n} / \mathrm{a}$ & 12.8 & 2.7 & 43.8 & 44.5 & 11.7 \\
\hline 22 & CT10-7i & 1.30 & 0.51 & 0.25 & 3.14 & 6.94 & $\mathrm{n} / \mathrm{a}$ & $\mathrm{n} / \mathrm{a}$ & 18.6 & 3.3 & 56.3 & 34.2 & 9.5 \\
\hline
\end{tabular}

C-10 
Table C-1. Measured soil properties for the Gleason Fire site, 2009-2012. MAB = months after burn, $\rho_{b}=$ bulk density, $f=$ porosity,

$w=$ gravimetric soil moisture, $K_{s}=$ saturated hydraulic conductivity, $k_{a}=$ air permeability, WDPT = water drop penetration time,

$\mathrm{OM}=$ organic matter. A date of $-0.13 \mathrm{MAB}$ represents four days before the fire of August 13, 2009; 0.16 MAB represents five

days after the fire. An entry of " $\mathrm{n} / \mathrm{a}$ " means data were unavailable (continued).

\begin{tabular}{|c|c|c|c|c|c|c|c|c|c|c|c|c|c|}
\hline $\begin{array}{c}\text { Date } \\
(\mathrm{MAB})\end{array}$ & ID & $\begin{array}{c}\rho_{b} \\
\left(\mathrm{~g} \mathrm{~cm}^{-3}\right)\end{array}$ & $\begin{array}{c}f \\
\left(\mathrm{vol} \mathrm{vol}^{-1}\right)\end{array}$ & $\begin{array}{c}w \\
\left(\mathrm{~g} \mathrm{~g}^{-1}\right)\end{array}$ & $\begin{array}{c}K_{s} \\
\left(\mathrm{~cm} \mathrm{hr}^{-1}\right)\end{array}$ & $\begin{array}{c}k_{a} \\
\left(\mu \mathrm{m}^{2}\right)\end{array}$ & $\begin{array}{c}\text { WDPT } \\
{[\mathrm{s}]}\end{array}$ & $\begin{array}{c}\text { ash } \\
{[\mathrm{cm}]}\end{array}$ & $\begin{array}{c}\text { Gravel } \\
{[\%]}\end{array}$ & $\begin{array}{l}\mathrm{OM} \\
{[\%]}\end{array}$ & $\begin{array}{c}\text { Sand } \\
{[\%]}\end{array}$ & $\begin{array}{l}\text { Silt } \\
{[\%]}\end{array}$ & $\begin{array}{l}\text { Clay } \\
{[\%]}\end{array}$ \\
\hline 22 & CT10-8c & 1.53 & 0.42 & 0.34 & 4.23 & 14.34 & $\mathrm{n} / \mathrm{a}$ & $\mathrm{n} / \mathrm{a}$ & 16.9 & 3.8 & 52.1 & 37.2 & 10.6 \\
\hline 25 & BR21B-1c & 1.48 & 0.44 & 0.32 & 5.48 & 4.20 & 0.0 & 0.0 & 14.8 & 4.0 & 53.1 & 38.9 & 8.0 \\
\hline 25 & BR21B-2i & 1.50 & 0.43 & 0.31 & 4.11 & 5.63 & 0.0 & 0.0 & 17.5 & 4.1 & 48.3 & 42.0 & 9.8 \\
\hline 25 & BR21B-3c & 1.44 & 0.46 & 0.25 & 6.03 & 6.52 & 0.0 & 0.0 & & & & & \\
\hline 25 & BR21B-4i & 1.59 & 0.40 & 0.31 & 6.02 & 6.77 & 0.0 & 0.0 & 14.2 & 3.5 & 45.1 & 46.1 & 8.8 \\
\hline 25 & BR21B-5i & 1.46 & 0.45 & 0.32 & 2.75 & 7.48 & 0.0 & 0.0 & & & & & \\
\hline 25 & BR21B-6c & 1.35 & 0.49 & 0.33 & 7.62 & 8.18 & 0.0 & 0.0 & 15.6 & 4.5 & 63.9 & 29.8 & 6.3 \\
\hline 25 & BR21B-7i & 1.40 & 0.47 & 0.37 & 0.05 & 8.58 & 2.7 & 0.0 & & & & & \\
\hline 25 & BR21B-8c & 1.59 & 0.40 & 0.30 & 3.36 & 10.95 & 0.0 & 0.0 & & & & & \\
\hline 25 & BR22-1i & 2.02 & 0.24 & 0.32 & 5.61 & 6.76 & 0.0 & 0.0 & 29.2 & 2.6 & 53.3 & 39.0 & 7.7 \\
\hline 25 & BR22-2i & 1.51 & 0.43 & 0.28 & 1.97 & 4.07 & 0.0 & 0.0 & & & & & \\
\hline 25 & BR22-3c & 1.55 & 0.41 & 0.30 & 2.09 & 12.78 & 4.7 & 0.0 & 21.0 & 2.8 & 54.1 & 38.3 & 7.7 \\
\hline 25 & BR22-4i & 1.58 & 0.40 & 0.28 & 3.74 & 7.73 & 0.0 & 0.0 & 32.0 & 3.4 & 44.9 & 45.5 & 9.6 \\
\hline 25 & BR22-5c & 1.58 & 0.41 & 0.29 & 2.23 & 7.31 & 0.0 & 1.0 & & & & & \\
\hline 25 & BR22-6c & 1.33 & 0.50 & 0.34 & 2.75 & 5.67 & 0.0 & 8.0 & & & & & \\
\hline 25 & BR22-7c & 1.10 & 0.59 & 0.28 & 0.40 & 4.17 & 0.0 & 0.0 & 11.7 & 5.0 & 50.3 & 39.9 & 9.7 \\
\hline 25 & BR22-8i & 1.47 & 0.45 & 0.32 & 0.87 & 5.31 & 0.0 & 1.0 & & & & & \\
\hline 25 & BR23-1i & 1.39 & 0.48 & 0.28 & 1.55 & 3.16 & 0.0 & 1.0 & & & & & \\
\hline 25 & BR23-2i & 1.65 & 0.38 & 0.31 & 0.62 & 2.06 & 0.0 & 1.0 & 24.5 & 2.6 & 44.2 & 47.4 & 8.4 \\
\hline 25 & BR23-3c & 1.24 & 0.53 & 0.31 & 3.49 & 8.16 & 0.0 & 4.0 & & & & & \\
\hline 25 & BR23-4c & 1.37 & 0.48 & 0.44 & 3.75 & 9.98 & 26.7 & 6.0 & & & & & \\
\hline 25 & BR23-5c & 1.35 & 0.49 & 0.39 & 3.80 & 5.14 & 1.3 & 0.0 & 15.4 & 4.5 & 37.2 & 52.0 & 10.8 \\
\hline 25 & BR23-6i & 1.40 & 0.47 & 0.27 & 3.30 & 6.67 & 0.0 & 3.0 & & & & & \\
\hline 25 & BR23-7c & 1.52 & 0.43 & 0.29 & 3.57 & 8.89 & 2.3 & 2.0 & 16.8 & 3.7 & 54.8 & 38.2 & 7.0 \\
\hline 25 & BR23-8i & 1.76 & 0.34 & 0.30 & 3.07 & 7.63 & 0.0 & 0.0 & 14.3 & 3.4 & 35.4 & 55.9 & 8.7 \\
\hline 25 & BR24-1i & 1.57 & 0.41 & 0.38 & 2.67 & 6.39 & 0.0 & 0.0 & & & & & \\
\hline 25 & BR24-2i & 1.29 & 0.51 & 0.33 & 5.21 & 9.83 & 0.0 & 0.0 & 22.4 & 6.1 & 65.8 & 26.7 & 7.5 \\
\hline 25 & BR24-3c & 1.29 & 0.51 & 0.33 & 3.75 & 8.83 & 0.0 & 0.0 & 31.4 & 5.7 & 58.4 & 33.5 & 8.1 \\
\hline 25 & BR24-4i & 1.62 & 0.39 & 0.31 & 1.49 & 4.62 & 0.0 & 0.0 & & & & & \\
\hline 25 & BR24-5c & 1.42 & 0.46 & 0.40 & 1.37 & 3.50 & 1.3 & 0.0 & & & & & \\
\hline 25 & BR24-6i & 1.44 & 0.46 & 0.31 & 3.59 & 10.16 & 0.0 & 0.0 & 27.1 & 4.6 & 56.7 & 34.9 & 8.4 \\
\hline
\end{tabular}


Table C-1. Measured soil properties for the Gleason Fire site, 2009-2012. MAB = months after burn, $\rho_{b}=$ bulk density, $f=$ porosity,

$w=$ gravimetric soil moisture, $K_{s}=$ saturated hydraulic conductivity, $k_{a}=$ air permeability, WDPT = water drop penetration time,

$\mathrm{OM}=$ organic matter. A date of $-0.13 \mathrm{MAB}$ represents four days before the fire of August 13, 2009; 0.16 MAB represents five

days after the fire. An entry of " $\mathrm{n} / \mathrm{a}$ " means data were unavailable (continued).

\begin{tabular}{|c|c|c|c|c|c|c|c|c|c|c|c|c|c|}
\hline $\begin{array}{c}\text { Date } \\
\text { (MAB) }\end{array}$ & ID & $\begin{array}{c}\rho_{b} \\
\left(\mathrm{~g} \mathrm{~cm}^{-3}\right)\end{array}$ & $\begin{array}{c}f \\
\left(\mathrm{vol} \mathrm{vol}^{-1}\right)\end{array}$ & $\begin{array}{c}w \\
\left(\mathrm{~g} \mathrm{~g}^{-1}\right)\end{array}$ & $\begin{array}{c}K_{s} \\
\left(\mathrm{~cm} \mathrm{hr}^{-1}\right)\end{array}$ & $\begin{array}{c}k_{a} \\
\left(\mu \mathrm{m}^{2}\right)\end{array}$ & $\begin{array}{c}\text { WDPT } \\
{[\mathrm{s}]}\end{array}$ & $\begin{array}{c}\text { ash } \\
{[\mathrm{cm}]}\end{array}$ & $\begin{array}{c}\text { Gravel } \\
{[\%]}\end{array}$ & $\begin{array}{l}\mathrm{OM} \\
{[\%]}\end{array}$ & $\begin{array}{c}\text { Sand } \\
{[\%]}\end{array}$ & $\begin{array}{l}\text { Silt } \\
{[\%]}\end{array}$ & $\begin{array}{l}\text { Clay } \\
{[\%]}\end{array}$ \\
\hline 25 & BR24-7c & 1.32 & 0.50 & 0.37 & 4.40 & 4.50 & 0.0 & 0.0 & & & & & \\
\hline 25 & BR24-8c & 1.26 & 0.52 & 0.36 & 3.19 & 8.69 & 0.0 & 0.0 & 15.8 & 5.2 & 50.6 & 40.0 & 9.4 \\
\hline 25 & BR25-1i & 1.67 & 0.37 & 0.36 & 2.95 & 9.57 & 0.0 & 0.0 & 15.6 & 4.0 & 47.6 & 41.7 & 10.8 \\
\hline 25 & BR25-2i & 1.54 & 0.42 & 0.34 & 1.74 & 8.98 & 0.0 & 0.0 & & & & & \\
\hline 25 & BR25-3c & 0.97 & 0.63 & 0.23 & 5.67 & 4.55 & 0.0 & 0.0 & 27.5 & 6.1 & 55.1 & 36.8 & 8.1 \\
\hline 25 & BR25-4c & 1.64 & 0.38 & 0.30 & 1.65 & 11.35 & 0.0 & 0.0 & & & & & \\
\hline 25 & BR25-5c & 1.54 & 0.42 & 0.31 & 2.62 & 14.94 & 0.0 & 0.0 & 22.9 & 4.5 & 46.8 & 43.0 & 10.2 \\
\hline 25 & BR25-6i & 1.58 & 0.40 & 0.30 & 1.50 & 9.78 & 0.0 & 0.0 & 35.6 & 5.0 & 42.9 & 45.2 & 11.9 \\
\hline 25 & BR25-7i & 1.33 & 0.50 & 0.37 & 6.13 & 8.20 & 1.3 & 1.0 & & & & & \\
\hline 25 & BR25-8c & 1.58 & 0.41 & 0.41 & 5.46 & 6.53 & 1.0 & 2.0 & & & & & \\
\hline 25 & CT11-1i & 1.65 & 0.38 & 0.26 & 0.36 & 6.55 & $\mathrm{n} / \mathrm{a}$ & 0.0 & 21.3 & 4.2 & 41.3 & 48.1 & 10.6 \\
\hline 25 & CT11-2c & 1.47 & 0.44 & 0.24 & 4.70 & 11.14 & $\mathrm{n} / \mathrm{a}$ & 0.0 & & & & & \\
\hline 25 & CT11-3c & 1.42 & 0.47 & 0.20 & 4.40 & 9.44 & $\mathrm{n} / \mathrm{a}$ & 0.0 & 32.7 & 3.9 & 49.2 & 42.7 & 8.1 \\
\hline 25 & CT11-4c & 1.56 & 0.41 & 0.28 & 0.67 & 13.39 & $\mathrm{n} / \mathrm{a}$ & 0.0 & & & & & \\
\hline 25 & CT11-5c & 1.51 & 0.43 & 0.24 & 1.50 & 4.17 & $\mathrm{n} / \mathrm{a}$ & 0.0 & 14.2 & 4.0 & 39.0 & 50.1 & 10.9 \\
\hline 25 & CT11-6i & 1.46 & 0.45 & 0.14 & 0.42 & 13.58 & $\mathrm{n} / \mathrm{a}$ & 0.0 & & & & & \\
\hline 25 & CT11-7i & 1.42 & 0.46 & 0.22 & 55.84 & 12.05 & $\mathrm{n} / \mathrm{a}$ & 0.0 & 10.4 & 4.0 & 35.4 & 53.3 & 11.3 \\
\hline 25 & CT11-8i & 1.40 & 0.47 & 0.20 & 0.22 & 7.93 & $\mathrm{n} / \mathrm{a}$ & 0.0 & & & & & \\
\hline 25 & CT12-1i & 1.75 & 0.34 & 0.34 & 8.18 & 6.04 & $\mathrm{n} / \mathrm{a}$ & 0.0 & & & & & \\
\hline 25 & CT12-2i & 1.43 & 0.46 & 0.24 & 2.25 & 15.99 & $\mathrm{n} / \mathrm{a}$ & 0.0 & 15.5 & 3.9 & 37.4 & 50.2 & 12.4 \\
\hline 25 & CT12-3c & 1.43 & 0.46 & 0.25 & 1.67 & 19.59 & $\mathrm{n} / \mathrm{a}$ & 0.0 & 17.3 & 4.8 & 39.4 & 47.4 & 13.2 \\
\hline 25 & CT12-4i & 1.50 & 0.43 & 0.26 & 0.64 & 14.09 & $\mathrm{n} / \mathrm{a}$ & 0.0 & & & & & \\
\hline 25 & CT12-5c & 1.51 & 0.43 & 0.30 & 3.95 & 11.70 & $\mathrm{n} / \mathrm{a}$ & 0.0 & 20.3 & 6.6 & 54.3 & 34.8 & 11.0 \\
\hline 25 & СТ12-6c & 1.29 & 0.51 & 0.19 & 4.58 & 18.27 & $\mathrm{n} / \mathrm{a}$ & 0.0 & & & & & \\
\hline 25 & CT12-7c & 1.32 & 0.50 & 0.34 & 5.03 & 15.92 & $\mathrm{n} / \mathrm{a}$ & 0.0 & & & & & \\
\hline 25 & CT12-8i & 1.43 & 0.46 & 0.25 & 2.09 & 7.43 & $\mathrm{n} / \mathrm{a}$ & 0.0 & 19.0 & 0.1 & 38.4 & 51.9 & 9.7 \\
\hline 34 & BR26-1c & 1.23 & 0.53 & 0.32 & 12.46 & $\mathrm{n} / \mathrm{a}$ & $\mathrm{n} / \mathrm{a}$ & $\mathrm{n} / \mathrm{a}$ & 10.3 & 3.1 & 62.1 & 29.9 & 8.0 \\
\hline 34 & BR26-2i & 1.35 & 0.49 & 0.28 & 8.19 & $\mathrm{n} / \mathrm{a}$ & $\mathrm{n} / \mathrm{a}$ & $\mathrm{n} / \mathrm{a}$ & 9.9 & 2.8 & 60.1 & 31.3 & 8.6 \\
\hline 34 & BR26-3c & 1.25 & 0.53 & 0.35 & 14.79 & $\mathrm{n} / \mathrm{a}$ & $\mathrm{n} / \mathrm{a}$ & $\mathrm{n} / \mathrm{a}$ & 9.8 & 3.5 & 63.7 & 29.4 & 6.9 \\
\hline 34 & BR26-4i & 1.34 & 0.49 & 0.26 & 5.57 & $\mathrm{n} / \mathrm{a}$ & $\mathrm{n} / \mathrm{a}$ & $\mathrm{n} / \mathrm{a}$ & 12.5 & 2.5 & 51.7 & 41.2 & 7.1 \\
\hline 34 & BR26-5i & 1.48 & 0.44 & 0.28 & 1.95 & $\mathrm{n} / \mathrm{a}$ & $\mathrm{n} / \mathrm{a}$ & $\mathrm{n} / \mathrm{a}$ & 12.9 & 3.6 & 41.0 & 47.1 & 11.9 \\
\hline
\end{tabular}

C-12 
Table C-1. Measured soil properties for the Gleason Fire site, 2009-2012. MAB = months after burn, $\rho_{b}=$ bulk density, $f=$ porosity, $w=$ gravimetric soil moisture, $K_{s}=$ saturated hydraulic conductivity, $k_{a}=$ air permeability, WDPT = water drop penetration time,

$\mathrm{OM}=$ organic matter. A date of $-0.13 \mathrm{MAB}$ represents four days before the fire of August 13, 2009; 0.16 MAB represents five days after the fire. An entry of " $\mathrm{n} / \mathrm{a}$ " means data were unavailable (continued).

\begin{tabular}{|c|c|c|c|c|c|c|c|c|c|c|c|c|c|}
\hline $\begin{array}{c}\text { Date } \\
(\mathrm{MAB})\end{array}$ & ID & $\begin{array}{c}\rho_{b} \\
\left(\mathrm{~g} \mathrm{~cm}^{-3}\right)\end{array}$ & $\begin{array}{c}f \\
\left(\mathrm{vol} \mathrm{vol}^{-1}\right)\end{array}$ & $\begin{array}{c}w \\
\left(\mathrm{~g} \mathrm{~g}^{-1}\right)\end{array}$ & $\begin{array}{c}K_{s} \\
\left(\mathrm{~cm} \mathrm{hr}^{-1}\right)\end{array}$ & $\begin{array}{c}k_{a} \\
\left(\mu \mathrm{m}^{2}\right)\end{array}$ & $\begin{array}{c}\text { WDPT } \\
{[\mathrm{s}]}\end{array}$ & $\begin{array}{c}\text { ash } \\
{[\mathrm{cm}]}\end{array}$ & $\begin{array}{c}\text { Gravel } \\
{[\%]}\end{array}$ & $\begin{array}{l}\mathrm{OM} \\
{[\%]}\end{array}$ & $\begin{array}{c}\text { Sand } \\
{[\%]}\end{array}$ & $\begin{array}{l}\text { Silt } \\
{[\%]}\end{array}$ & $\begin{array}{l}\text { Clay } \\
{[\%]}\end{array}$ \\
\hline 34 & BR26-6c & 1.41 & 0.47 & 0.33 & 7.79 & $\mathrm{n} / \mathrm{a}$ & $\mathrm{n} / \mathrm{a}$ & $\mathrm{n} / \mathrm{a}$ & 10.3 & 3.1 & 55.7 & 36.4 & 7.8 \\
\hline 34 & BR26-7c & 1.10 & 0.58 & 0.27 & 8.24 & $\mathrm{n} / \mathrm{a}$ & $\mathrm{n} / \mathrm{a}$ & $\mathrm{n} / \mathrm{a}$ & 12.8 & 3.9 & 54.2 & 37.0 & 8.7 \\
\hline 34 & BR26-8i & 1.62 & 0.39 & 0.32 & 10.16 & $\mathrm{n} / \mathrm{a}$ & $\mathrm{n} / \mathrm{a}$ & $\mathrm{n} / \mathrm{a}$ & 10.8 & 3.7 & 44.6 & 45.5 & 9.9 \\
\hline 34 & BR27-1i & 1.36 & 0.49 & 0.15 & 3.41 & $\mathrm{n} / \mathrm{a}$ & $\mathrm{n} / \mathrm{a}$ & $\mathrm{n} / \mathrm{a}$ & 23.3 & 2.8 & 45.7 & 45.5 & 8.8 \\
\hline 34 & BR27-2c & 1.35 & 0.49 & 0.25 & 19.37 & $\mathrm{n} / \mathrm{a}$ & $\mathrm{n} / \mathrm{a}$ & $\mathrm{n} / \mathrm{a}$ & 7.8 & 3.4 & 55.3 & 37.1 & 7.6 \\
\hline 34 & BR27-3c & 1.53 & 0.42 & 0.24 & 3.44 & $\mathrm{n} / \mathrm{a}$ & $\mathrm{n} / \mathrm{a}$ & $\mathrm{n} / \mathrm{a}$ & 23.1 & 3.1 & 48.2 & 42.1 & 9.8 \\
\hline 34 & BR27-4c & 1.38 & 0.48 & 0.32 & 13.34 & $\mathrm{n} / \mathrm{a}$ & $\mathrm{n} / \mathrm{a}$ & $\mathrm{n} / \mathrm{a}$ & 4.7 & 3.3 & 43.0 & 47.1 & 9.9 \\
\hline 34 & BR27-5i & 1.45 & 0.45 & 0.18 & 6.75 & $\mathrm{n} / \mathrm{a}$ & $\mathrm{n} / \mathrm{a}$ & $\mathrm{n} / \mathrm{a}$ & 21.4 & 2.9 & 55.5 & 37.6 & 6.9 \\
\hline 34 & BR27-6i & 1.11 & 0.58 & 0.18 & 2.95 & $\mathrm{n} / \mathrm{a}$ & $\mathrm{n} / \mathrm{a}$ & $\mathrm{n} / \mathrm{a}$ & 15.4 & 3.3 & 56.9 & 34.9 & 8.2 \\
\hline 34 & BR27-7c & 1.35 & 0.49 & 0.32 & 7.64 & $\mathrm{n} / \mathrm{a}$ & $\mathrm{n} / \mathrm{a}$ & $\mathrm{n} / \mathrm{a}$ & 20.8 & 4.1 & 52.9 & 38.3 & 8.7 \\
\hline 34 & BR27-8i & 1.31 & 0.51 & 0.20 & 8.51 & $\mathrm{n} / \mathrm{a}$ & $\mathrm{n} / \mathrm{a}$ & $\mathrm{n} / \mathrm{a}$ & 21.0 & 3.6 & 64.5 & 28.6 & 6.9 \\
\hline 34 & BR28-1c & 1.27 & 0.52 & 0.19 & 7.52 & $\mathrm{n} / \mathrm{a}$ & $\mathrm{n} / \mathrm{a}$ & $\mathrm{n} / \mathrm{a}$ & 24.9 & 3.9 & 56.9 & 34.8 & 8.4 \\
\hline 34 & BR28-2c & 1.23 & 0.54 & 0.28 & 9.10 & $\mathrm{n} / \mathrm{a}$ & $\mathrm{n} / \mathrm{a}$ & $\mathrm{n} / \mathrm{a}$ & 11.7 & 4.7 & 50.5 & 39.1 & 10.4 \\
\hline 34 & BR28-3i & 1.21 & 0.54 & 0.24 & 6.06 & $\mathrm{n} / \mathrm{a}$ & $\mathrm{n} / \mathrm{a}$ & $\mathrm{n} / \mathrm{a}$ & 14.8 & 4.7 & 52.7 & 38.5 & 8.9 \\
\hline 34 & BR28-4i & 1.37 & 0.48 & 0.28 & 6.81 & $\mathrm{n} / \mathrm{a}$ & $\mathrm{n} / \mathrm{a}$ & $\mathrm{n} / \mathrm{a}$ & 5.7 & 3.7 & 50.3 & 41.1 & 8.6 \\
\hline 34 & BR28-5i & 1.50 & 0.44 & 0.19 & 9.45 & $\mathrm{n} / \mathrm{a}$ & $\mathrm{n} / \mathrm{a}$ & $\mathrm{n} / \mathrm{a}$ & 20.9 & 3.4 & 53.6 & 38.8 & 7.7 \\
\hline 34 & BR28-6c & 1.23 & 0.54 & 0.23 & 18.68 & $\mathrm{n} / \mathrm{a}$ & $\mathrm{n} / \mathrm{a}$ & $\mathrm{n} / \mathrm{a}$ & 7.1 & 4.6 & 60.5 & 32.2 & 7.3 \\
\hline 34 & BR28-7c & 1.12 & 0.58 & 0.21 & 15.84 & $\mathrm{n} / \mathrm{a}$ & $\mathrm{n} / \mathrm{a}$ & $\mathrm{n} / \mathrm{a}$ & 7.7 & 4.1 & 55.5 & 36.3 & 8.3 \\
\hline 34 & BR28-8i & 1.36 & 0.49 & 0.19 & 5.55 & $\mathrm{n} / \mathrm{a}$ & $\mathrm{n} / \mathrm{a}$ & $\mathrm{n} / \mathrm{a}$ & 6.2 & 3.1 & 29.4 & 58.5 & 12.1 \\
\hline 34 & BR29-1c & 1.35 & 0.49 & 0.28 & 8.12 & $\mathrm{n} / \mathrm{a}$ & $\mathrm{n} / \mathrm{a}$ & $\mathrm{n} / \mathrm{a}$ & 16.1 & 3.4 & 43.4 & 44.8 & 11.9 \\
\hline 34 & BR29-2c & 1.11 & 0.58 & 0.30 & 14.37 & $\mathrm{n} / \mathrm{a}$ & $\mathrm{n} / \mathrm{a}$ & $\mathrm{n} / \mathrm{a}$ & 9.2 & 3.8 & 46.0 & 40.6 & 13.3 \\
\hline 34 & BR29-3i & 1.35 & 0.49 & 0.22 & 10.07 & $\mathrm{n} / \mathrm{a}$ & $\mathrm{n} / \mathrm{a}$ & $\mathrm{n} / \mathrm{a}$ & 20.8 & 2.8 & 41.7 & 46.8 & 11.4 \\
\hline 34 & BR29-4c & 1.24 & 0.53 & 0.26 & 8.51 & $\mathrm{n} / \mathrm{a}$ & $\mathrm{n} / \mathrm{a}$ & $\mathrm{n} / \mathrm{a}$ & 16.9 & 3.4 & 53.0 & 37.0 & 10.0 \\
\hline 34 & BR29-5i & 1.25 & 0.53 & 0.22 & 7.23 & $\mathrm{n} / \mathrm{a}$ & $\mathrm{n} / \mathrm{a}$ & $\mathrm{n} / \mathrm{a}$ & 16.1 & 2.9 & 40.6 & 47.0 & 12.4 \\
\hline 34 & BR29-6i & 1.36 & 0.49 & 0.23 & 3.63 & $\mathrm{n} / \mathrm{a}$ & $\mathrm{n} / \mathrm{a}$ & $\mathrm{n} / \mathrm{a}$ & 9.6 & 3.3 & 34.8 & 52.6 & 12.7 \\
\hline 34 & BR29-7c & 1.27 & 0.52 & 0.26 & 8.21 & $\mathrm{n} / \mathrm{a}$ & $\mathrm{n} / \mathrm{a}$ & $\mathrm{n} / \mathrm{a}$ & 9.2 & 3.2 & 55.9 & 35.4 & 8.7 \\
\hline 34 & BR29-8i & 1.36 & 0.49 & 0.22 & 8.27 & $\mathrm{n} / \mathrm{a}$ & $\mathrm{n} / \mathrm{a}$ & $\mathrm{n} / \mathrm{a}$ & 8.0 & 3.3 & 46.0 & 43.6 & 10.4 \\
\hline 34 & BR30-1c & 1.35 & 0.49 & 0.32 & 5.65 & $\mathrm{n} / \mathrm{a}$ & $\mathrm{n} / \mathrm{a}$ & $\mathrm{n} / \mathrm{a}$ & 6.2 & 4.2 & 32.2 & 51.5 & 16.3 \\
\hline 34 & BR30-2c & 1.51 & 0.43 & 0.32 & 7.66 & $\mathrm{n} / \mathrm{a}$ & $\mathrm{n} / \mathrm{a}$ & $\mathrm{n} / \mathrm{a}$ & 9.3 & 4.0 & 39.1 & 46.5 & 14.4 \\
\hline 34 & BR30-3i & 1.47 & 0.44 & 0.34 & 4.82 & $\mathrm{n} / \mathrm{a}$ & $\mathrm{n} / \mathrm{a}$ & $\mathrm{n} / \mathrm{a}$ & 9.1 & 3.4 & 37.3 & 48.8 & 14.0 \\
\hline 34 & BR30-4i & 1.36 & 0.49 & 0.31 & 9.68 & $\mathrm{n} / \mathrm{a}$ & $\mathrm{n} / \mathrm{a}$ & $\mathrm{n} / \mathrm{a}$ & 7.8 & 3.7 & 34.4 & 49.7 & 15.9 \\
\hline
\end{tabular}


Table C-1. Measured soil properties for the Gleason Fire site, 2009-2012. MAB = months after burn, $\rho_{b}=$ bulk density, $f=$ porosity, $w=$ gravimetric soil moisture, $K_{s}=$ saturated hydraulic conductivity, $k_{a}=$ air permeability, WDPT $=$ water drop penetration time, $\mathrm{OM}=$ organic matter. A date of $-0.13 \mathrm{MAB}$ represents four days before the fire of August 13, 2009; 0.16 MAB represents five days after the fire. An entry of "n/a" means data were unavailable (continued).

\begin{tabular}{|c|c|c|c|c|c|c|c|c|c|c|c|c|c|}
\hline $\begin{array}{c}\text { Date } \\
(\mathrm{MAB})\end{array}$ & ID & $\begin{array}{c}\rho_{b} \\
\left(\mathrm{~g} \mathrm{~cm}^{-3}\right)\end{array}$ & $\begin{array}{c}f \\
\left(\mathrm{vol} \mathrm{vol}^{-1}\right)\end{array}$ & $\begin{array}{c}w \\
\left(\mathrm{~g} \mathrm{~g}^{-1}\right)\end{array}$ & $\begin{array}{c}K_{s} \\
\left(\mathrm{~cm} \mathrm{hr}^{-1}\right)\end{array}$ & $\begin{array}{c}k_{a} \\
\left(\mu \mathrm{m}^{2}\right)\end{array}$ & $\begin{array}{c}\text { WDPT } \\
{[\mathrm{s}]}\end{array}$ & $\begin{array}{c}\text { ash } \\
{[\mathrm{cm}]}\end{array}$ & $\begin{array}{c}\text { Gravel } \\
{[\%]}\end{array}$ & $\begin{array}{l}\mathrm{OM} \\
{[\%]}\end{array}$ & $\begin{array}{c}\text { Sand } \\
{[\%]}\end{array}$ & $\begin{array}{l}\text { Silt } \\
{[\%]}\end{array}$ & $\begin{array}{l}\text { Clay } \\
{[\%]}\end{array}$ \\
\hline 34 & BR30-5i & 1.35 & 0.49 & 0.26 & 4.96 & $\mathrm{n} / \mathrm{a}$ & $\mathrm{n} / \mathrm{a}$ & $\mathrm{n} / \mathrm{a}$ & 18.6 & 3.1 & 47.6 & 41.8 & 10.6 \\
\hline 34 & BR30-6c & 1.46 & 0.45 & 0.24 & 10.42 & $\mathrm{n} / \mathrm{a}$ & $\mathrm{n} / \mathrm{a}$ & $\mathrm{n} / \mathrm{a}$ & 39.4 & 3.7 & 55.4 & 36.1 & 8.5 \\
\hline 34 & BR30-7i & 1.50 & 0.43 & 0.34 & 10.23 & $\mathrm{n} / \mathrm{a}$ & $\mathrm{n} / \mathrm{a}$ & $\mathrm{n} / \mathrm{a}$ & 13.9 & 3.5 & 41.1 & 46.1 & 12.8 \\
\hline 34 & BR30-8c & 1.26 & 0.52 & 0.31 & 7.10 & $\mathrm{n} / \mathrm{a}$ & $\mathrm{n} / \mathrm{a}$ & $\mathrm{n} / \mathrm{a}$ & 16.4 & 3.4 & 42.5 & 45.1 & 12.4 \\
\hline 34 & CT13-1c & 1.30 & 0.51 & 0.34 & 11.92 & $\mathrm{n} / \mathrm{a}$ & $\mathrm{n} / \mathrm{a}$ & $\mathrm{n} / \mathrm{a}$ & 8.2 & 3.1 & 60.6 & 32.8 & 6.7 \\
\hline 34 & CT13-2c & 1.41 & 0.47 & 0.30 & 8.22 & $\mathrm{n} / \mathrm{a}$ & $\mathrm{n} / \mathrm{a}$ & $\mathrm{n} / \mathrm{a}$ & 13.1 & 2.5 & 64.2 & 29.5 & 6.3 \\
\hline 34 & CT13-3i & 1.60 & 0.39 & 0.22 & 7.37 & $\mathrm{n} / \mathrm{a}$ & $\mathrm{n} / \mathrm{a}$ & $\mathrm{n} / \mathrm{a}$ & 37.9 & 2.5 & 64.9 & 28.5 & 6.6 \\
\hline 34 & CT13-4i & 1.38 & 0.48 & 0.17 & 13.40 & $\mathrm{n} / \mathrm{a}$ & $\mathrm{n} / \mathrm{a}$ & $\mathrm{n} / \mathrm{a}$ & 23.6 & 2.3 & 64.9 & 28.3 & 6.8 \\
\hline 34 & CT13-5i & 1.43 & 0.46 & 0.25 & 1.14 & $\mathrm{n} / \mathrm{a}$ & $\mathrm{n} / \mathrm{a}$ & $\mathrm{n} / \mathrm{a}$ & 6.8 & 2.1 & 36.7 & 52.0 & 11.3 \\
\hline 34 & CT13-6i & 1.67 & 0.37 & 0.25 & 8.65 & $\mathrm{n} / \mathrm{a}$ & $\mathrm{n} / \mathrm{a}$ & $\mathrm{n} / \mathrm{a}$ & 27.3 & 2.5 & 61.9 & 30.0 & 8.1 \\
\hline 34 & CT13-7c & 1.43 & 0.46 & 0.28 & 30.75 & $\mathrm{n} / \mathrm{a}$ & $\mathrm{n} / \mathrm{a}$ & $\mathrm{n} / \mathrm{a}$ & 22.2 & 2.8 & 56.0 & 35.4 & 8.6 \\
\hline 34 & CT13-8c & 1.14 & 0.57 & 0.33 & 22.63 & $\mathrm{n} / \mathrm{a}$ & $\mathrm{n} / \mathrm{a}$ & $\mathrm{n} / \mathrm{a}$ & 4.3 & 3.7 & 57.0 & 34.2 & 8.9 \\
\hline 34 & CT14-1c & 1.37 & 0.48 & 0.28 & 29.25 & $\mathrm{n} / \mathrm{a}$ & $\mathrm{n} / \mathrm{a}$ & $\mathrm{n} / \mathrm{a}$ & 8.1 & 3.1 & 53.0 & 37.1 & 9.9 \\
\hline 34 & CT14-2i & 1.25 & 0.53 & 0.36 & 13.74 & $\mathrm{n} / \mathrm{a}$ & $\mathrm{n} / \mathrm{a}$ & $\mathrm{n} / \mathrm{a}$ & 8.4 & 4.4 & 56.9 & 33.4 & 9.7 \\
\hline 34 & CT14-3i & 1.23 & 0.54 & 0.29 & 8.92 & $\mathrm{n} / \mathrm{a}$ & $\mathrm{n} / \mathrm{a}$ & $\mathrm{n} / \mathrm{a}$ & 19.6 & 4.1 & 61.0 & 31.0 & 8.0 \\
\hline 34 & CT14-4c & 1.21 & 0.54 & 0.25 & 8.88 & $\mathrm{n} / \mathrm{a}$ & $\mathrm{n} / \mathrm{a}$ & $\mathrm{n} / \mathrm{a}$ & 13.5 & 2.6 & 64.3 & 28.6 & 7.1 \\
\hline 34 & CT14-5i & 1.47 & 0.44 & 0.26 & 8.93 & $\mathrm{n} / \mathrm{a}$ & $\mathrm{n} / \mathrm{a}$ & $\mathrm{n} / \mathrm{a}$ & 15.2 & 2.9 & 41.2 & 45.3 & 13.6 \\
\hline 34 & CT14-6c & 1.42 & 0.47 & 0.24 & 7.43 & $\mathrm{n} / \mathrm{a}$ & $\mathrm{n} / \mathrm{a}$ & $\mathrm{n} / \mathrm{a}$ & 22.9 & 2.9 & 53.5 & 35.9 & 10.6 \\
\hline 34 & CT14-7c & 1.05 & 0.60 & 0.32 & 2.54 & $\mathrm{n} / \mathrm{a}$ & $\mathrm{n} / \mathrm{a}$ & $\mathrm{n} / \mathrm{a}$ & 1.3 & 3.4 & 51.5 & 37.4 & 11.1 \\
\hline 34 & CT14-8i & 1.53 & 0.42 & 0.27 & 7.07 & $\mathrm{n} / \mathrm{a}$ & $\mathrm{n} / \mathrm{a}$ & $\mathrm{n} / \mathrm{a}$ & 21.8 & 2.8 & 49.8 & 40.0 & 10.3 \\
\hline
\end{tabular}


APPENDIX D: $\quad$ RAINFALL SIMULATOR HYDROGRAPHS, 2009-2012

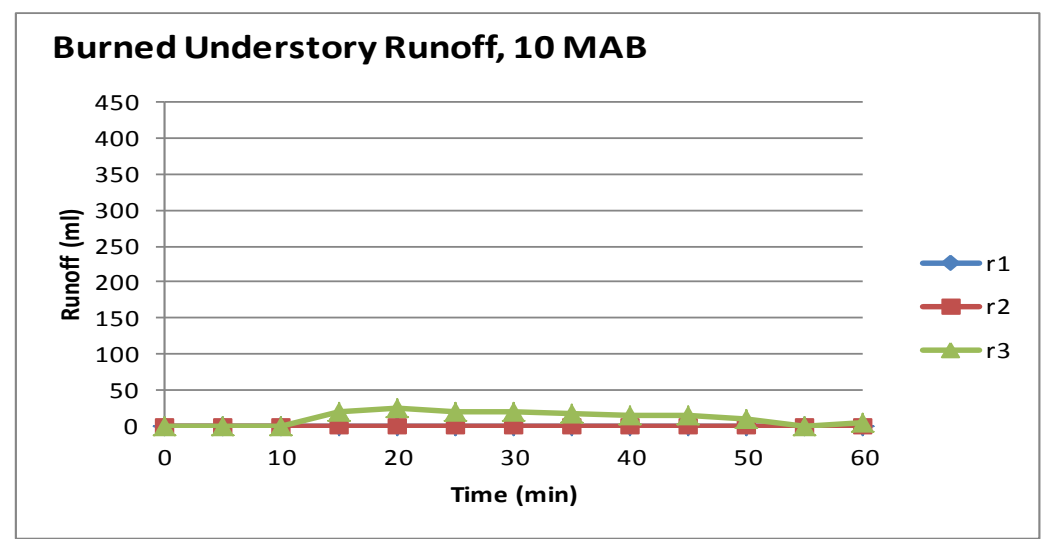

\section{Burned Interspace Runoff, 10 MAB}
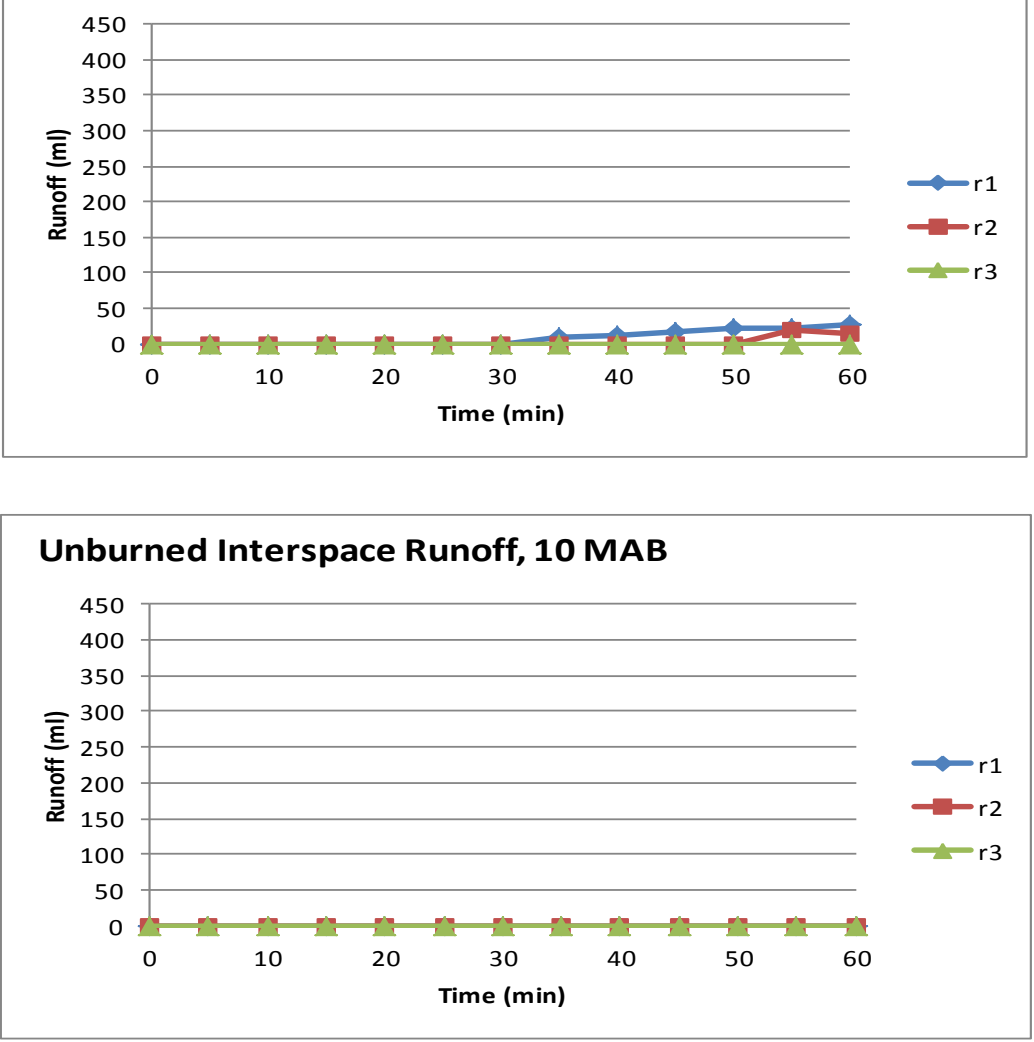

Figure D.1. Runoff hydrographs at $10 \mathrm{MAB}$; "r1, r2, r3" indicate replicates 1, 2, and 3, respectively. 

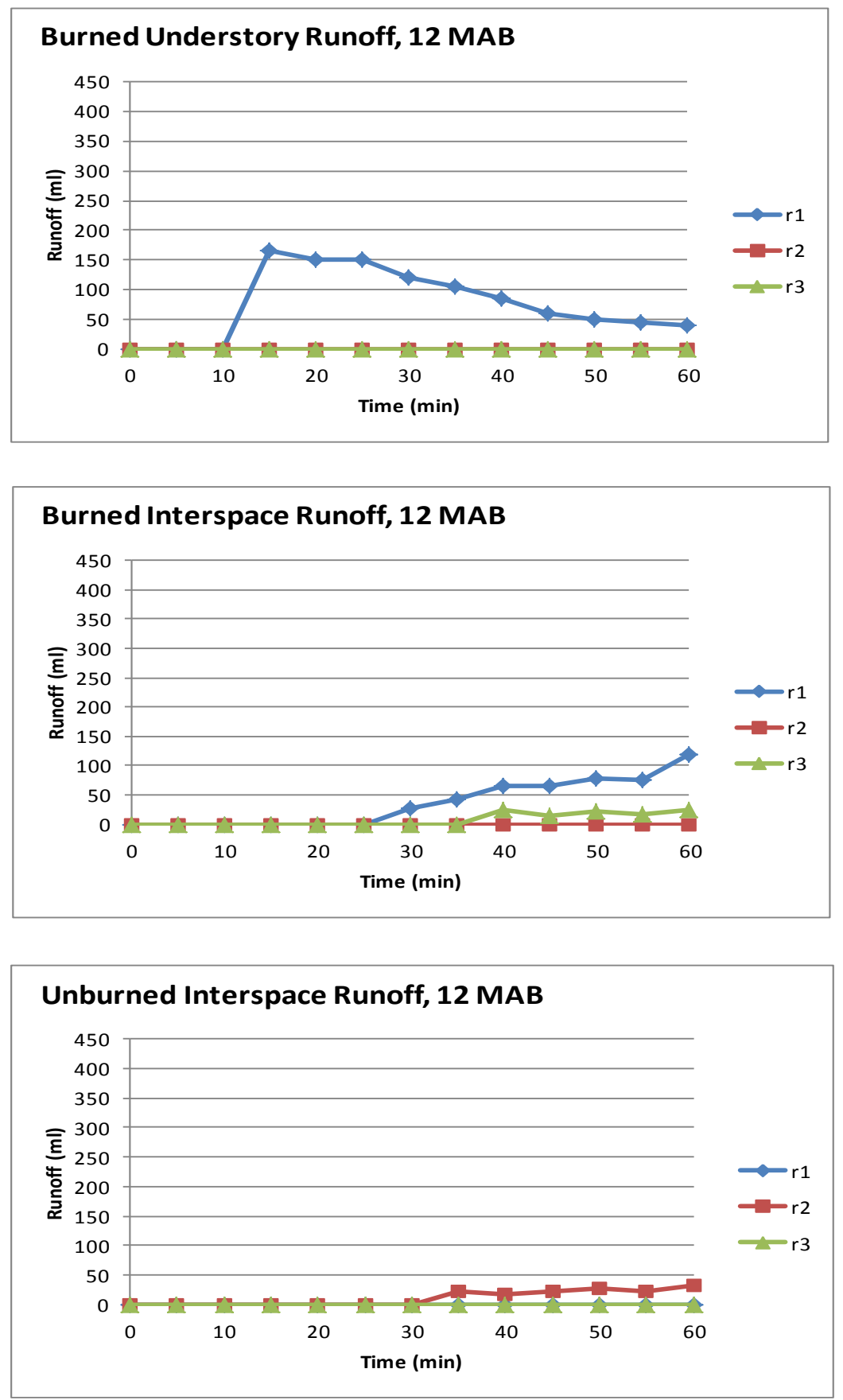

Figure D.2. Runoff hydrographs at $12 \mathrm{MAB}$; "r1, r2, r3" indicate replicates 1, 2, and 3, respectively. 

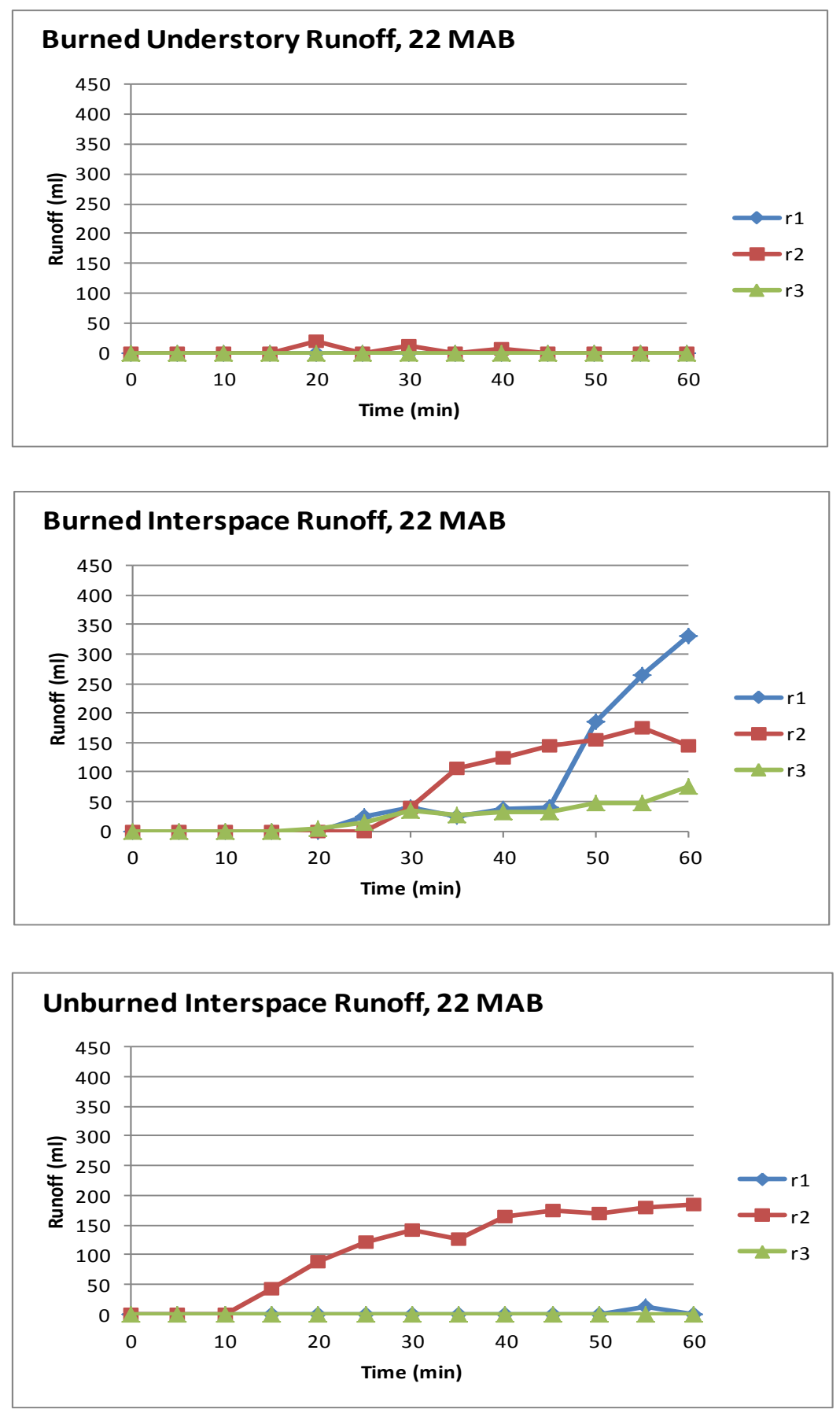

Figure D.3. Runoff hydrographs at $22 \mathrm{MAB}$; “r1, r2, r3" indicate replicates 1, 2, and 3, respectively. 

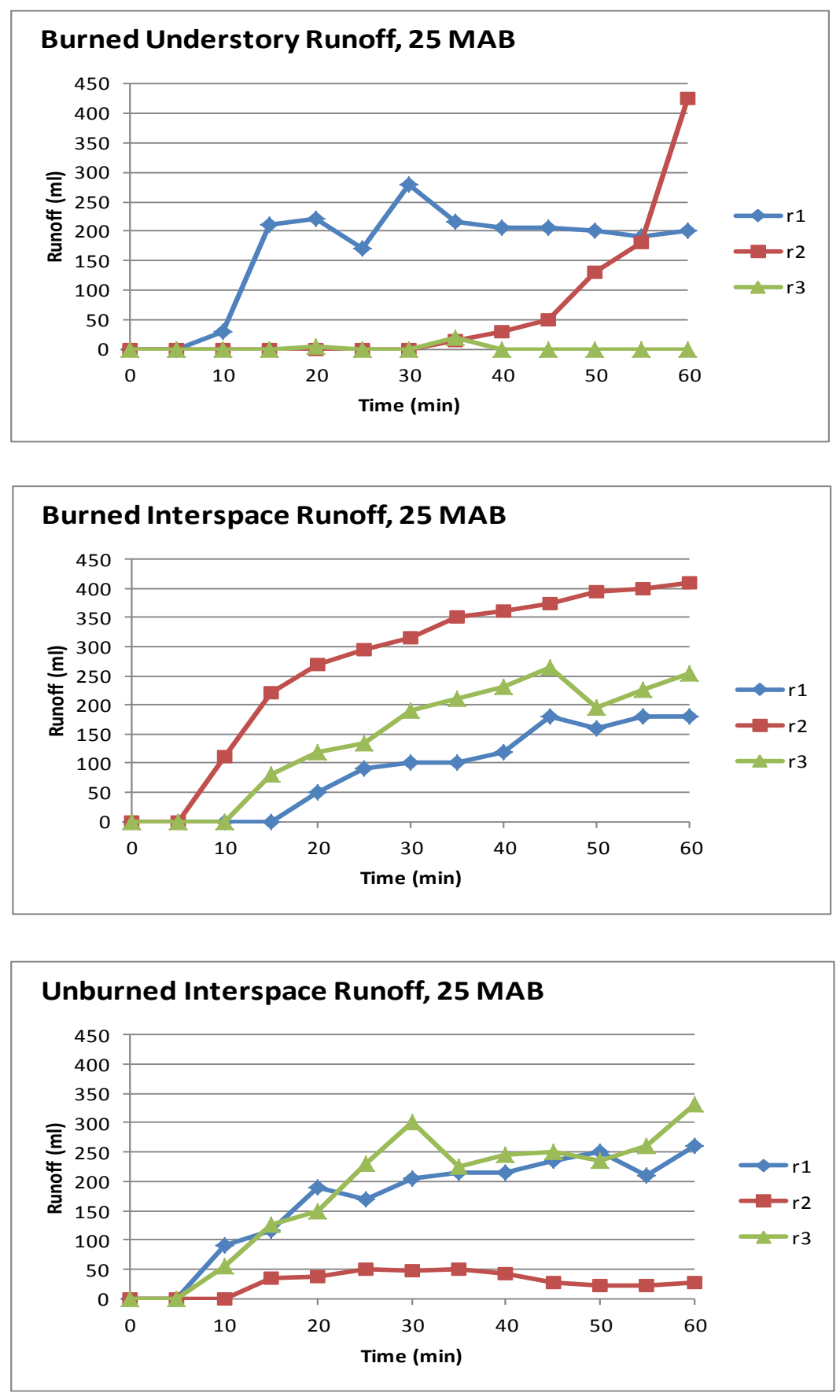

Figure D.4. Runoff hydrographs at $25 \mathrm{MAB}$; “r1, r2, r3" indicate replicates 1, 2, and 3, respectively. 

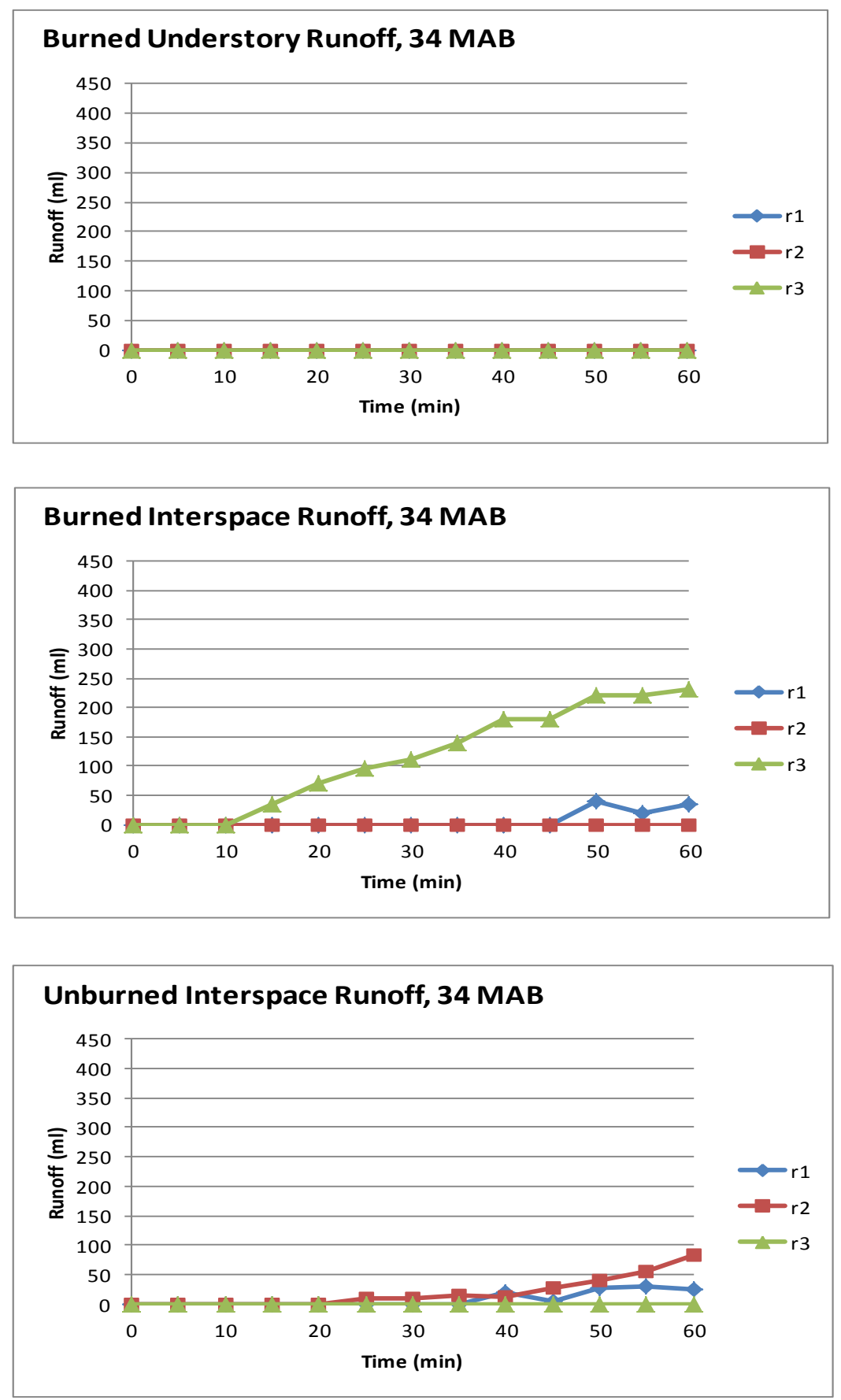

Figure D.5. Runoff hydrographs at $34 \mathrm{MAB}$; "r1, r2, r3" indicate replicates 1, 2, and 3, respectively. 
APPENDIX E: $\quad$ SOIL MOISTURE DURING RAINFALL SIMULATION, 2009-2012
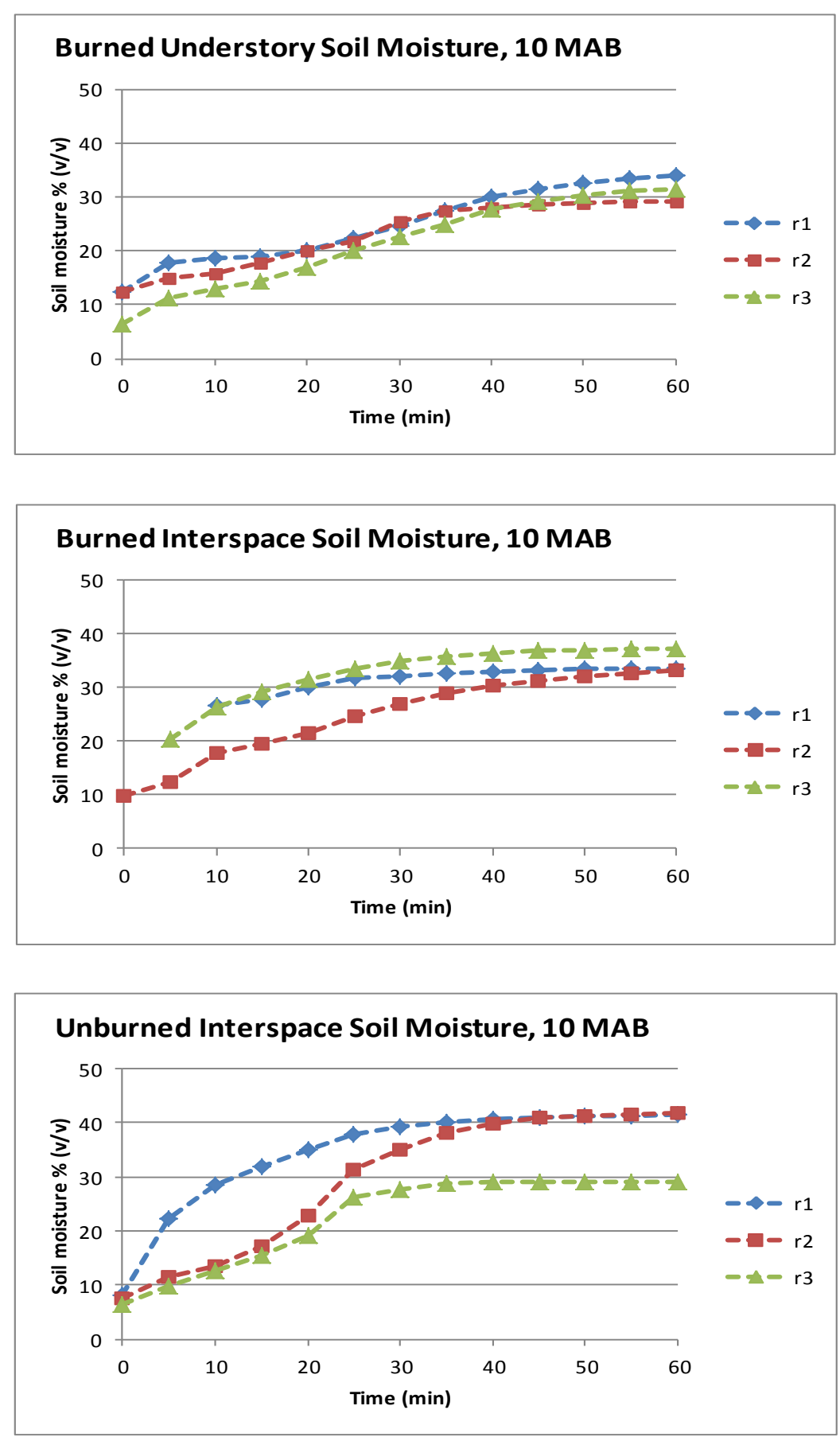

Figure E.1. Soil moisture readings from rainfall simulations at $10 \mathrm{MAB}$; "r1, r2, r3" indicate replicates 1,2 , and 3 , respectively. 

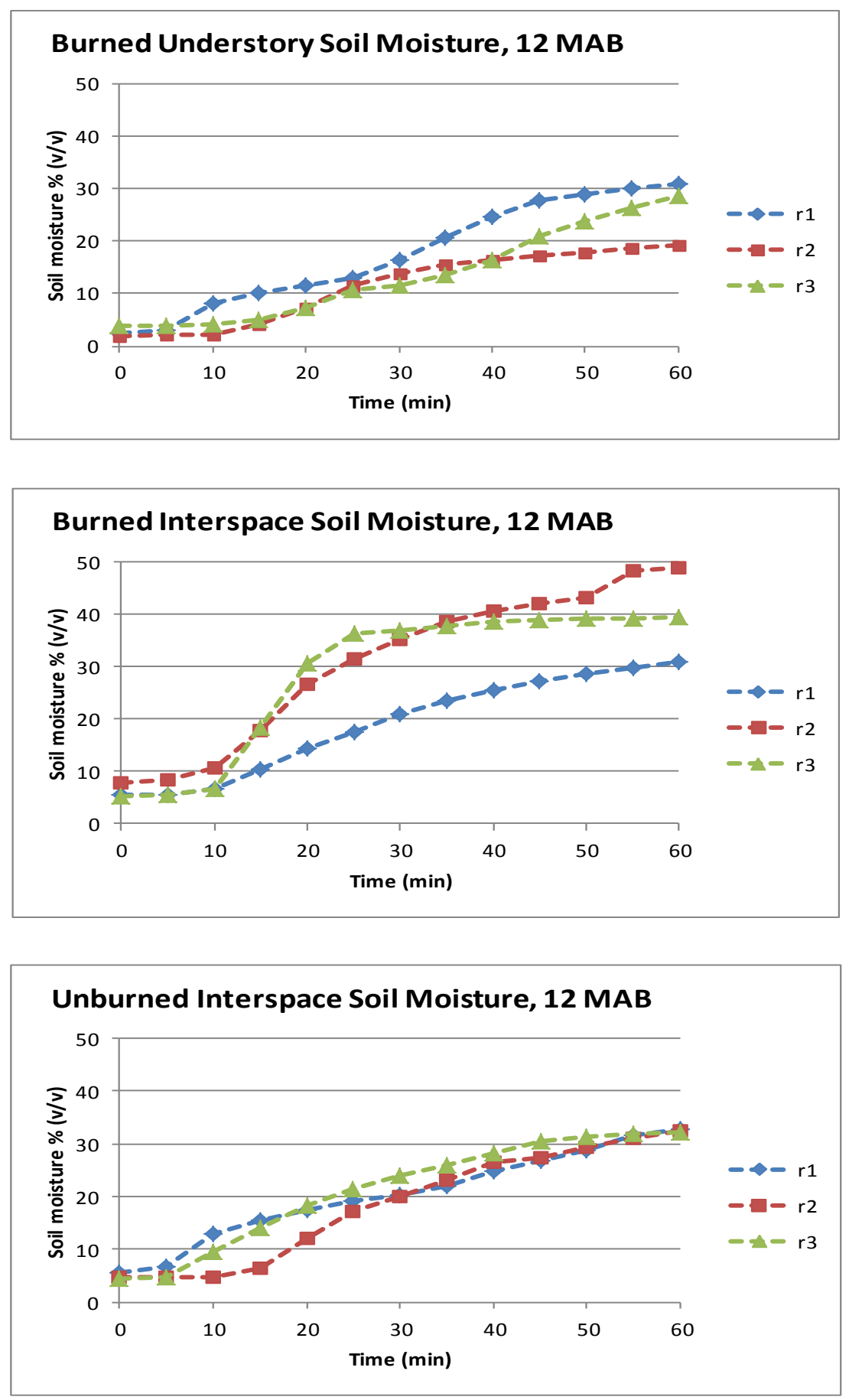

Figure E.2. Soil moisture readings from rainfall simulations at 12 MAB; "r1, r2, r3" indicate replicates 1,2 , and 3 , respectively. 

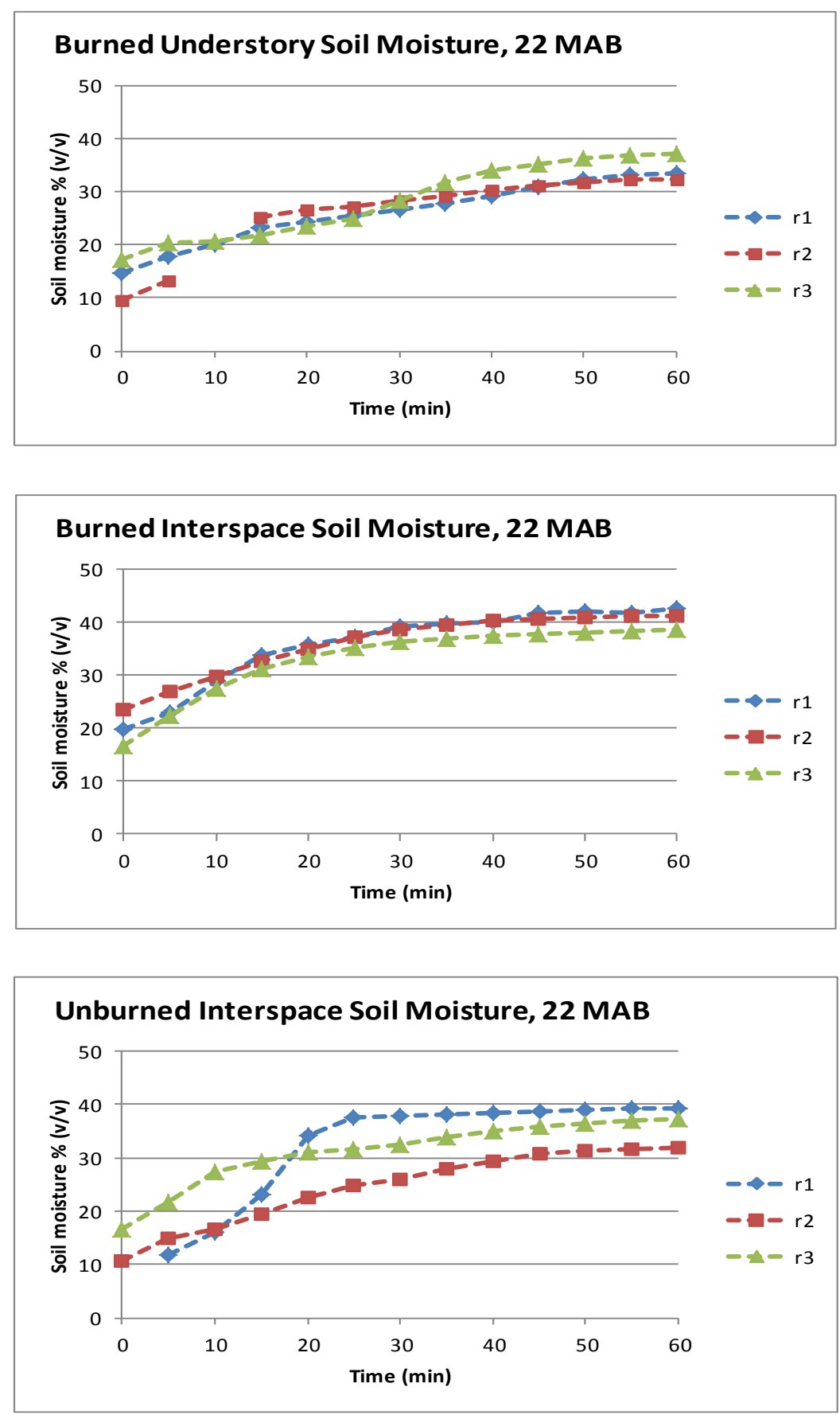

Figure E.3. Soil moisture readings from rainfall simulations at $22 \mathrm{MAB}$; "r1, r2, r3" indicate replicates 1,2 , and 3 , respectively. 

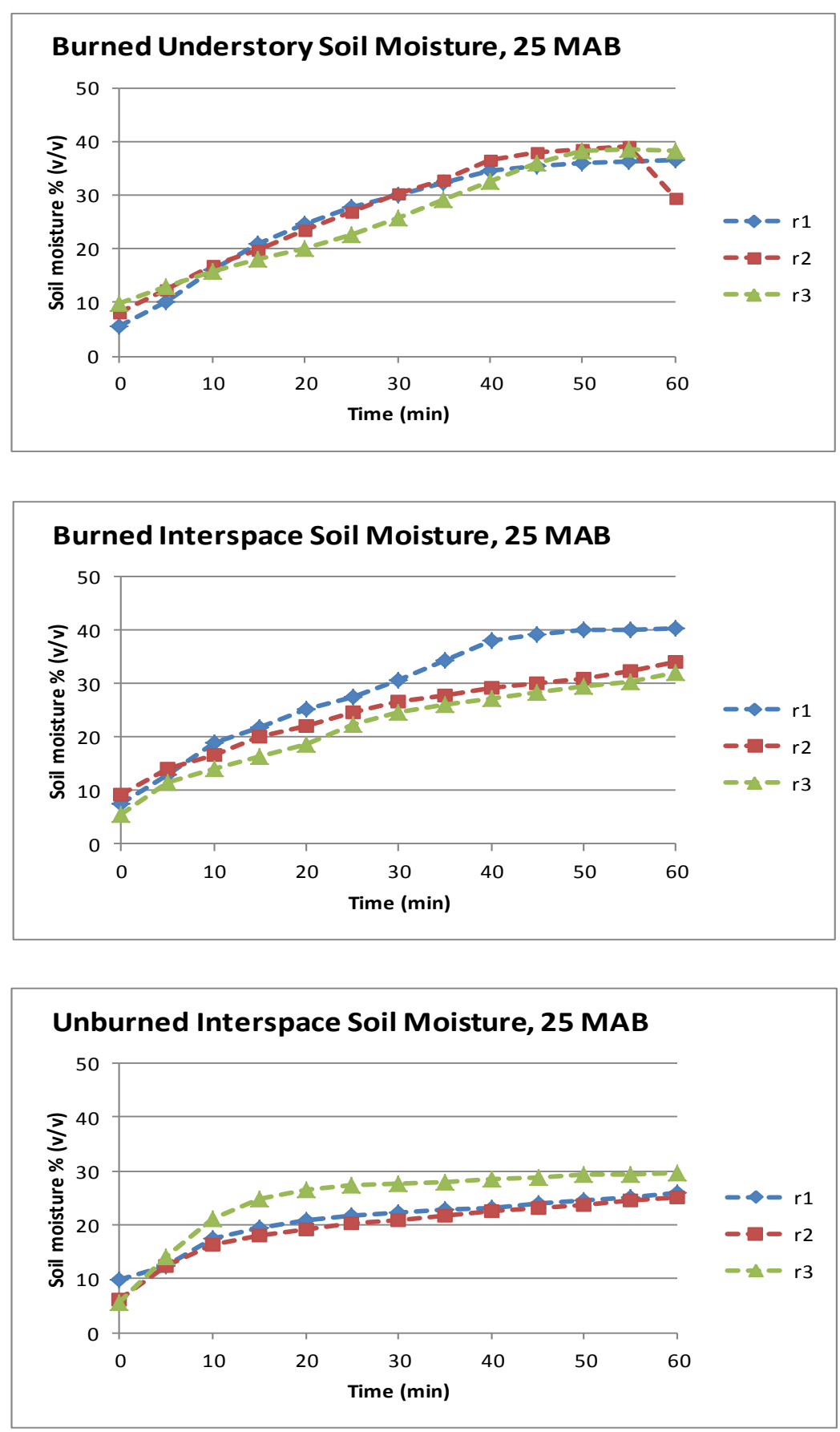

Figure E.4. Soil moisture readings from rainfall simulations at 25 MAB; "r1, r2, r3" indicate replicates 1,2 , and 3 , respectively. 

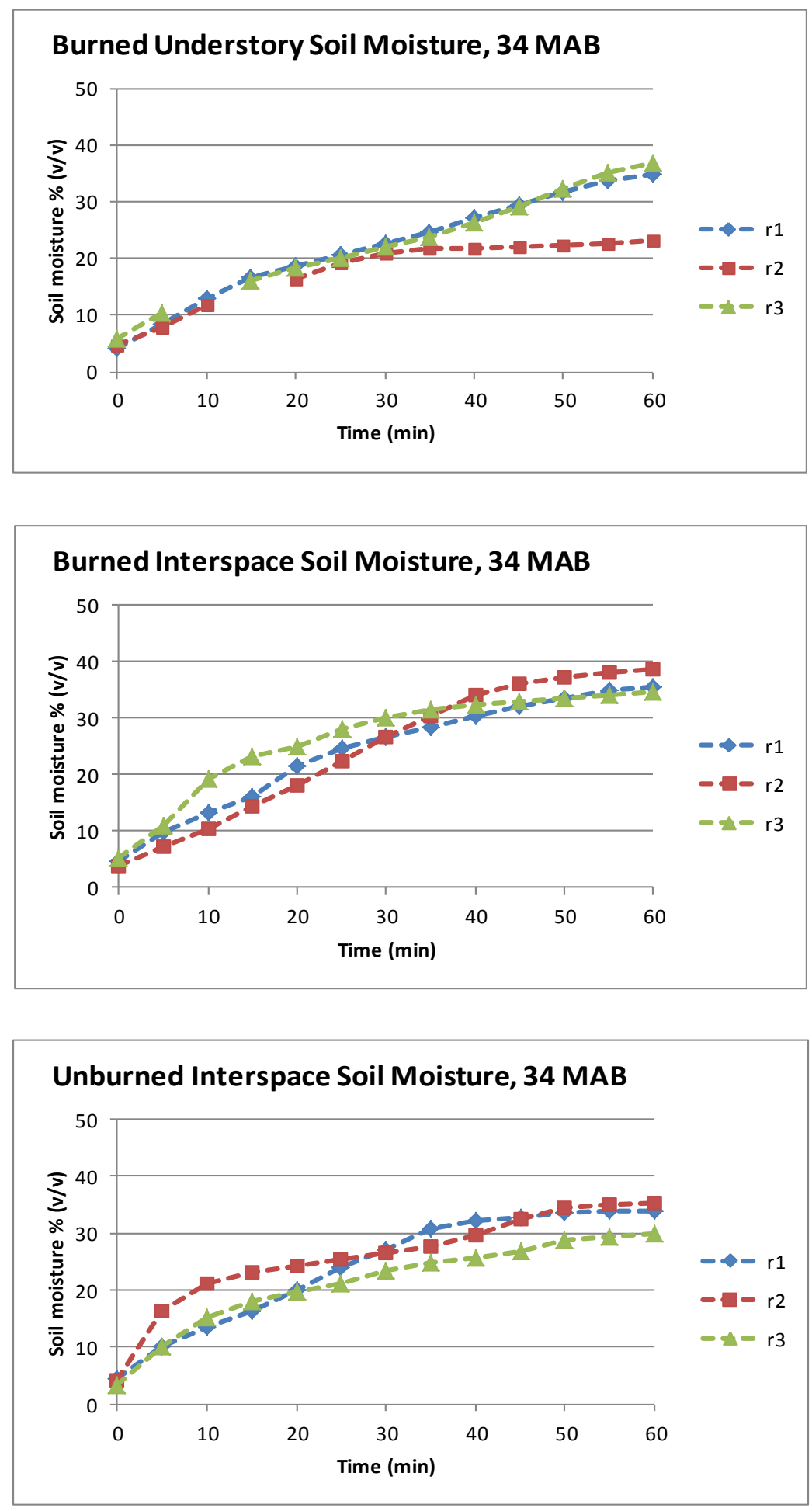

Figure E.5. Soil moisture readings from rainfall simulations at $34 \mathrm{MAB}$; "r1, r2, r3" indicate replicates 1,2 , and 3 , respectively. 


\section{APPENDIX F: CURVE NUMBERS}

Table F-1. Curve numbers (CNs) calculated for the Gleason Fire site, 2009-2012. The entry n/a" indicates no runoff was recorded and no $\mathrm{CN}$ could be calculated.

\begin{tabular}{|c|c|c|c|c|c|}
\hline \multirow[t]{2}{*}{ Surface } & \multirow[t]{2}{*}{ MAB } & \multicolumn{4}{|c|}{ Curve Numbers for Rainfall Simulation Tests } \\
\hline & & Ponding & Initial Runoff & All Quadrant Runoff & Initial Runoff to Trough \\
\hline \multirow[t]{15}{*}{ Unburned, Interspace } & 10 & 97 & 95 & 90 & $\mathrm{n} / \mathrm{a}$ \\
\hline & & 95 & 93 & 91 & $\mathrm{n} / \mathrm{a}$ \\
\hline & & 84 & 71 & $\mathrm{n} / \mathrm{a}$ & $\mathrm{n} / \mathrm{a}$ \\
\hline & 12 & 98 & 96 & 95 & $\mathrm{n} / \mathrm{a}$ \\
\hline & & 99 & 99 & 96 & 77 \\
\hline & & 99 & 96 & 80 & 62 \\
\hline & 22 & 94 & 86 & $\mathrm{n} / \mathrm{a}$ & 70 \\
\hline & & 93 & 92 & 86 & 92 \\
\hline & & 95 & 95 & 83 & $\mathrm{n} / \mathrm{a}$ \\
\hline & 25 & 100 & 99 & 97 & 95 \\
\hline & & 93 & 98 & 96 & 98 \\
\hline & & 99 & 97 & 95 & 94 \\
\hline & 34 & 96 & 95 & $\mathrm{n} / \mathrm{a}$ & 86 \\
\hline & & 94 & 91 & $\mathrm{n} / \mathrm{a}$ & 88 \\
\hline & & 94 & 93 & 89 & 72 \\
\hline \multirow[t]{15}{*}{ Burned, Interspace } & 10 & 91 & 91 & 88 & 75 \\
\hline & & $\mathrm{n} / \mathrm{a}$ & $\mathrm{n} / \mathrm{a}$ & $\mathrm{n} / \mathrm{a}$ & $\mathrm{n} / \mathrm{a}$ \\
\hline & & 98 & 97 & 94 & $\mathrm{n} / \mathrm{a}$ \\
\hline & 12 & 98 & 98 & 95 & 65 \\
\hline & & 97 & 96 & 92 & 62 \\
\hline & & 98 & 96 & 93 & 74 \\
\hline & 22 & 99 & 94 & 91 & 85 \\
\hline & & 96 & 95 & 91 & 79 \\
\hline & & 97 & 89 & 85 & 89 \\
\hline & 25 & 96 & 93 & 88 & 84 \\
\hline & & 98 & 97 & 95 & 95 \\
\hline & & 100 & 99 & 97 & 95 \\
\hline & 34 & 95 & 91 & 87 & 79 \\
\hline & & 82 & 82 & $\mathrm{n} / \mathrm{a}$ & 66 \\
\hline & & 95 & 95 & 88 & 83 \\
\hline \multirow[t]{2}{*}{ Burned, Understory } & 10 & $\mathrm{n} / \mathrm{a}$ & $\mathrm{n} / \mathrm{a}$ & $\mathrm{n} / \mathrm{a}$ & $\mathrm{n} / \mathrm{a}$ \\
\hline & & 88 & 86 & 85 & 84 \\
\hline
\end{tabular}


Table F-1. Curve numbers (CNs) calculated for the Gleason Fire site, 2009-2012. The entry "n/a" indicates no runoff was recorded and no $\mathrm{CN}$ could be calculated (continued).

\begin{tabular}{|c|c|c|c|c|c|}
\hline \multirow[t]{2}{*}{ Surface } & \multirow{2}{*}{ MAB } & \multicolumn{4}{|c|}{ Curve Numbers for Rainfall Simulation Tests } \\
\hline & & Ponding & Initial Runoff & All Quadrant Runoff & Initial Runoff to Trough \\
\hline \multirow{14}{*}{ Burned, Understory } & & 99 & 97 & 95 & 91 \\
\hline & 12 & 98 & 97 & 94 & 89 \\
\hline & & 97 & 94 & 90 & 82 \\
\hline & & 96 & 86 & 89 & 87 \\
\hline & & 99 & 98 & $\mathrm{n} / \mathrm{a}$ & $\mathrm{n} / \mathrm{a}$ \\
\hline & 22 & 95 & 87 & $\mathrm{n} / \mathrm{a}$ & $\mathrm{n} / \mathrm{a}$ \\
\hline & & 95 & 92 & $\mathrm{n} / \mathrm{a}$ & 87 \\
\hline & & 91 & 89 & $\mathrm{n} / \mathrm{a}$ & $\mathrm{n} / \mathrm{a}$ \\
\hline & 25 & 98 & 97 & 93 & 92 \\
\hline & & 97 & 94 & $\mathrm{n} / \mathrm{a}$ & 80 \\
\hline & & 96 & 94 & 77 & 88 \\
\hline & 34 & 97 & 97 & $\mathrm{n} / \mathrm{a}$ & 71 \\
\hline & & $\mathrm{n} / \mathrm{a}$ & $\mathrm{n} / \mathrm{a}$ & $\mathrm{n} / \mathrm{a}$ & $\mathrm{n} / \mathrm{a}$ \\
\hline & & $\mathrm{n} / \mathrm{a}$ & $\mathrm{n} / \mathrm{a}$ & $\mathrm{n} / \mathrm{a}$ & $\mathrm{n} / \mathrm{a}$ \\
\hline
\end{tabular}




\section{APPENDIX G: $\quad$ PLANT LIST AND CODES}

Table G-1. $\quad$ List of plant species and codes for vegetation at the Gleason Fire site. Names and codes from the USDA PLANTS database (USDA-NRCS, 2012).

\begin{tabular}{|c|c|c|c|c|c|c|}
\hline Family & Genus & Species & Life Form & Origin & Code & Common Name \\
\hline Asteraceae & Acamptopappus & sphaerocephalus & perennial shrub & native & ACSP & rayless goldenhead \\
\hline Poaceae & Achnatherum & hymenoides & perennial grass & native & ACHY & Indian ricegrass \\
\hline Asteraceae & Agoseris & glauca & annual forb & native & AGGL & mountain or false dandelion or pale agoseris \\
\hline Liliaceae & Allium & parvum & perennial forb & native & ALPA & small onion or dwarf onion \\
\hline Papaveraceae & Argemone & munita & perennial forb & native & ARMI & prickly poppy \\
\hline Poaceae & Aristida & purpurea & perennial grass & native & ARPU & purple three-awn \\
\hline Asteraceae & Artemisia & tridentata & perennial shrub & native & ARTR & big sagebrush \\
\hline Fabaceae & Astragalus & calycosus & perennial forb & native & ASCA & Torrey's milkvetch \\
\hline Fabaceae & Astragalus & lentiginosus & perennial forb & native & ASLE & spotted locoweed or freckled milkvetch \\
\hline Fabaceae & Astragalus & purshii & perennial forb & native & ASPU & woollypod milkvetch and Pursh's milkvetch \\
\hline Asteraceae & Aster & scopulorum & perennial forb & native & ASSC & now Ionactis alpina, or lava aster \\
\hline Poaceae & Bromus & tectorum & annual grass & introduced & BRTE & cheatgrass or drooping brome \\
\hline Scrophulariaceae & Castilleja & angustifolia & perennial forb & native & CAAN & northwestern or desert Indian paintbrush \\
\hline Liliaceae & Calochortus & eurycarpus & perennial forb & native & CAEU & white or wing-fruited mariposa lily \\
\hline Caryophyllaceae & Silene & $s p$. & annual forb & native & CARY & campion and catchfly \\
\hline Asteraceae & Chaenactis & douglasii & annual forb & native & CHDO & Douglas' dustymaiden \\
\hline Asteraceae & Chrysothamnus & greenei & perennial shrub & native & CHGR & Greene's rabbitbrush \\
\hline Scrophulariaceae & Collinsia & parviflora & annual forb & native & COPA & maiden blue-eyed Mary \\
\hline Boraginaceae & Cryptantha & utahensis & annual forb & native & CRAN & scented catseye or scented cryptantha \\
\hline Boraginaceae & Cryptantha & humilis & perennial forb & native & CRHU & round-headed cryptantha \\
\hline Boraginaceae & Cryptantha & micromera & annual forb & native & CRMI & (cannot find micromera) \\
\hline Boraginaceae & Cryptantha & nevadensis & annual forb & native & CRNE & Nevada cryptantha \\
\hline Ranunculaceae & Delphinium & andersonii & perennial forb & native & DEAN & Anderson's larkspur \\
\hline Brassicaceae & Descurainia & pinnata & annual forb & native & DEPI & western tansy mustard \\
\hline
\end{tabular}


Table G-1. $\quad$ List of plant species and codes for vegetation at the Gleason Fire site. Names and codes from the USDA PLANTS database (USDA-NRCS, 2012) (continued).

\begin{tabular}{|c|c|c|c|c|c|c|}
\hline Family & Genus & Species & Life Form & Origin & Code & Common Name \\
\hline Poaceae & Elymus & elymoides & perennial grass & native & ELEL & squirreltail \\
\hline Ephedraceae & Ephedra & viridis & perennial shrub & native & EPVI & mormon tea or green ephedra \\
\hline Polemoniaceae & Eriastrum & sparsiflorum & annual forb & native & ERSP & Great Basin or Harwood's woollystar \\
\hline Asteraceae & Erigeron & aphanactis & perennial forb & native & ERAP & rayless shaggy fleabane \\
\hline Asteraceae & Erigeron & eatonii & perennial forb & native & EREA & Eaton's fleabane \\
\hline Polygonaceae & Eriogonum & caespitosum & perennial forb & native & ERCE & matted or wild buckwheat \\
\hline Polygonaceae & Eriogonum & strictum & perennial forb & native & ERST & blue mountain buckwheat \\
\hline Poaceae & Erioneuron & pulchellum & perennial grass & native & ERPU & fluff grass; syn dasyochloa \\
\hline Cactaceae & Escobaria & vivipara & perennial forb & native & ESVI & spinystar \\
\hline Onagraceae & Gayophytum & diffusum & annual forb & native & GADI & spreading groundsmoke (evening primrose family) \\
\hline Polemoniaceae & Gilia & aliquanta & annual forb & native & GIAL & puffcalyx gilia (phlox family) \\
\hline Polemoniaceae & Gilia & cana & annual forb & native & GICA & showy gilia \\
\hline Polemoniaceae & Gilia & campanulata & annual forb & native & GICM & bellshape gilia \\
\hline Cupressaceae & Juniperus & osteosperma & perennial tree & native & JUOS & Utah juniper \\
\hline Brassicaceae & Lepidium & lasiocarpum & annual forb & native & LELA & shaggyfruit pepperweed \\
\hline Polemoniaceae & Leptodactylon & pungens & perennial forb & native & LEKI & granite gilia \\
\hline Brassicaceae & Lesquerella & kingii & annual forb & native & LEPU & king bladderpod \\
\hline Polemoniaceae & Linanthus & spp. & annual forb & native & LISP & phlox family \\
\hline Fabaceae & Lupinus & argenteus & perennial forb & native & LUAR & silvery lupine \\
\hline Loasaceae & Mentzelia & albicaulis & annual forb & native & MEAL & $\begin{array}{l}\text { whitestem blazing star, small flowered blazing } \\
\text { star, white stemmed stickleaf }\end{array}$ \\
\hline Polemoniaceae & Navarretia & divaricata & perennial forb & native & NADI & mountain navarretia (phlox family) \\
\hline Cactaceae & Opuntia & echinocarpa & perennial cactus & native & OPEC & silver or golden cholla \\
\hline Cactaceae & Opuntia & austrina & perennial cactus & native & OPPO & small devil's tongue \\
\hline Scrophulariaceae & Pedicularis & centranthera & perennial forb & native & PECE & dwarf lousewort \\
\hline Scrophulariaceae & Penstemon & ssp. & perennial forb & native & PESP & beardtongue \\
\hline Polemoniaceae & Phlox & hoodii & perennial forb & native & PHHO & spiny or carpet phlox \\
\hline
\end{tabular}


Table G-1. $\quad$ List of plant species and codes for vegetation at the Gleason Fire site. Names and codes from the USDA PLANTS database (USDA-NRCS, 2012) (continued).

\begin{tabular}{lllllll}
\hline Family & Genus & Species & Life Form & Origin & Code & Common Name \\
\hline Polemoniaceae & Phlox & longifolia & perennial forb & native & PHLO & long-leaf phlox \\
Polemoniaceae & Phlox & stansburyi & perennial forb & native & PHST & cold-desert or pink phlox \\
Pinaceae & Pinus & monophylla & perennial tree & native & PIMO & single-leaf pinyon pine \\
Rosaceae & Potentilla & gracilis & perennial forb & native & POGR & slender or graceful cinquefoil \\
Poaceae & Poa & secunda & perennial grass & native & POSE & pine, Sandberg or one-sided bluegrass
\end{tabular}

